\title{
Intramolecular Functionalization of Benzylic Methylene Adjacent to the Ring Nitrogen Atom
}

\author{
in $N$-Aryl Tetrahydroisoquinoline Derivatives \\ Liu Yang, ${ }^{\dagger}$ Daisy Zhang-Negrerie, ${ }^{\S}$ Kang Zhao,${ }^{\dagger}$ and Yunfei Du ${ }^{* \dagger,+}$ \\ ${ }^{\dagger}$ Tianjin Key Laboratory for Modern Drug Delivery \& High-Efficiency, School of Pharmaceutical Science and Technology, Tianjin University, \\ Tianjin 300072, China \\ $\neq$ Collaborative Innovation Center of Chemical Science and Engineering (Tianjin), Tianjin 300072, China

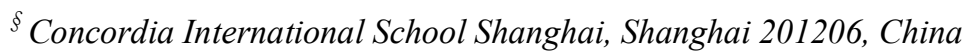 \\ duyunfeier@tju.edu.cn;kangzhao@tju.edu.cn
}

\section{Supporting Information}

Page

I. ${ }^{1} \mathrm{H}$ NMR and ${ }^{13} \mathrm{C}$ NMR Spectra of $\mathbf{1 c}-\mathbf{d}, \mathbf{1 g - k}, \mathbf{1 m - r}, \mathbf{1 t}$

II. ${ }^{1} \mathrm{H}$ NMR and ${ }^{13} \mathrm{C}$ NMR Spectra of $\mathbf{2 a - v}$

S30-S65

III. ${ }^{1} \mathrm{H}$ NMR and ${ }^{13} \mathrm{C}$ NMR Spectra of $\mathbf{2} \mathbf{I}^{\prime}, \mathbf{2} \mathbf{m}^{\prime}$

S67-S69 


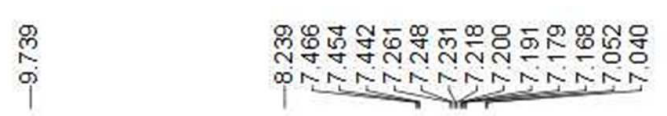

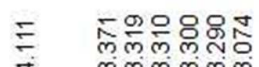

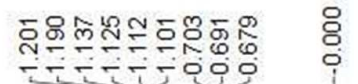

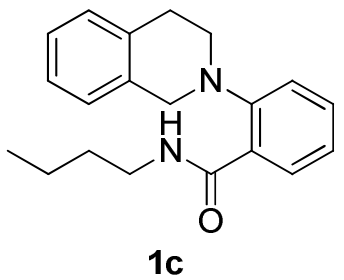

$1 c$

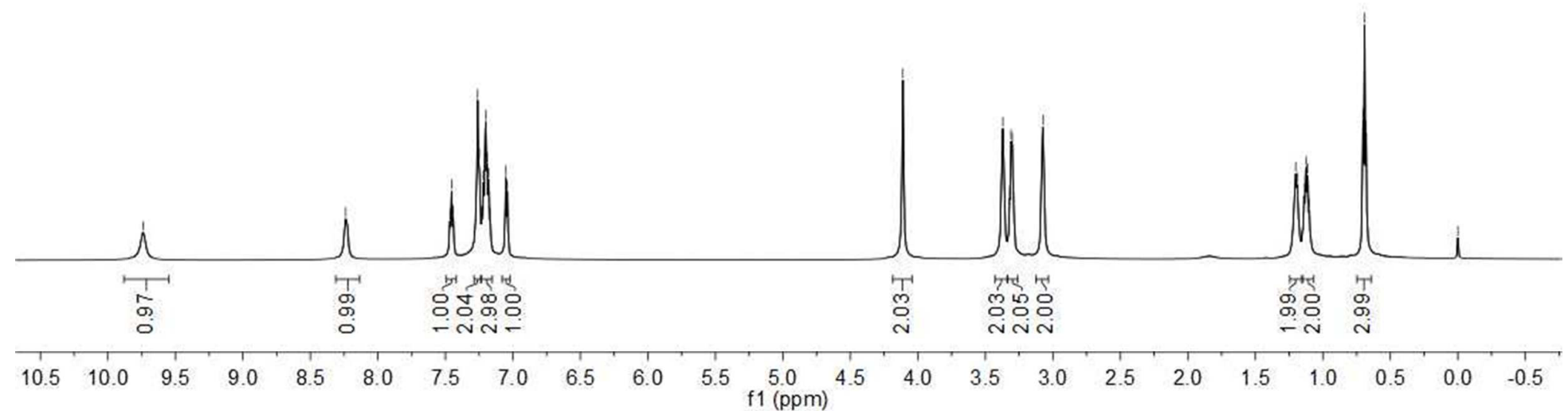




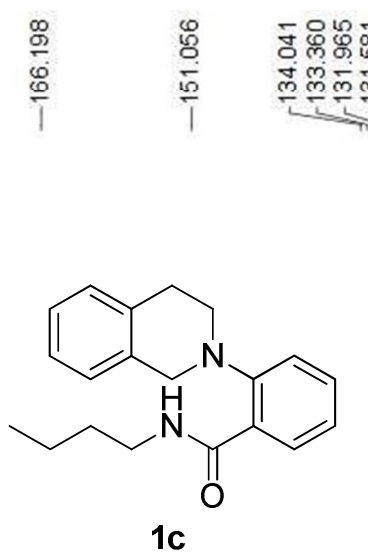

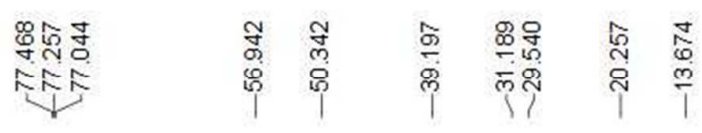

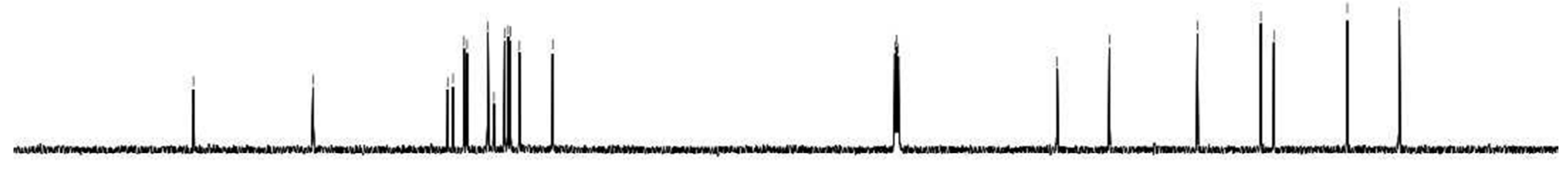

$180 \quad 1$

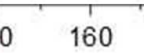

150

$140 \quad 130$

120

$100 \quad 90$

80

60 $50 \quad 40 \quad 30 \quad 20 \quad 10 \quad 1$, 


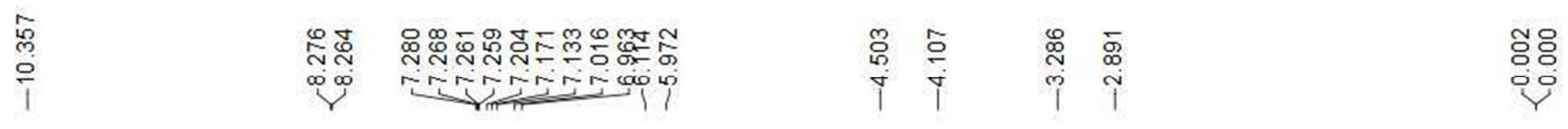

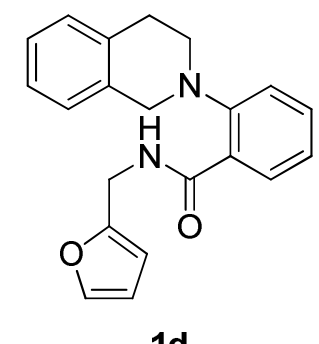

1d

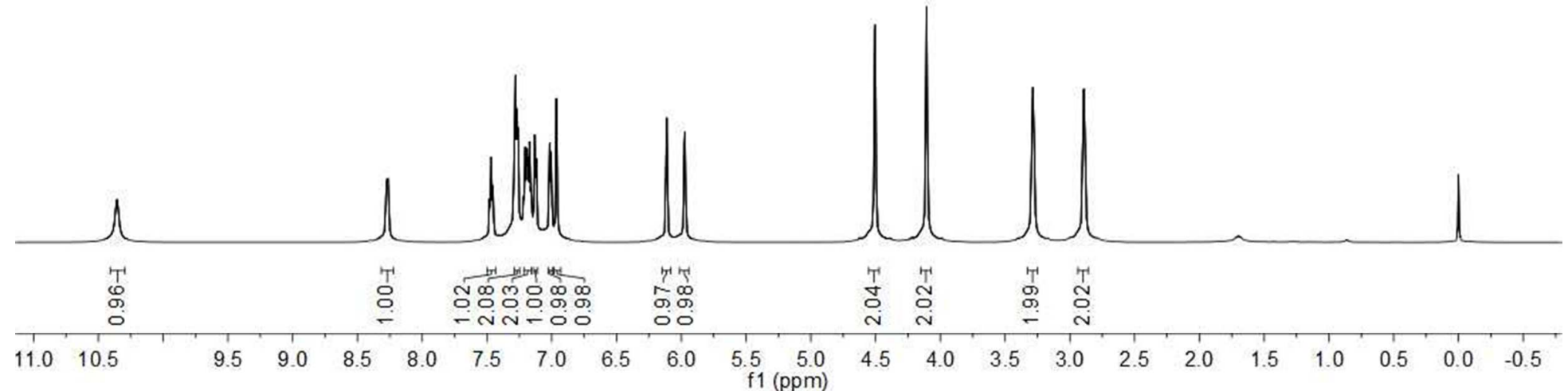




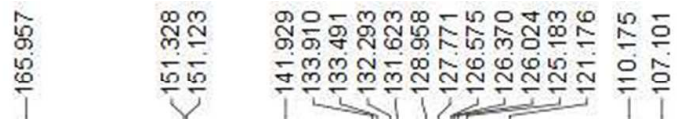

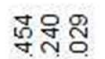

AN

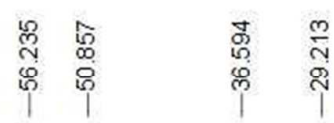
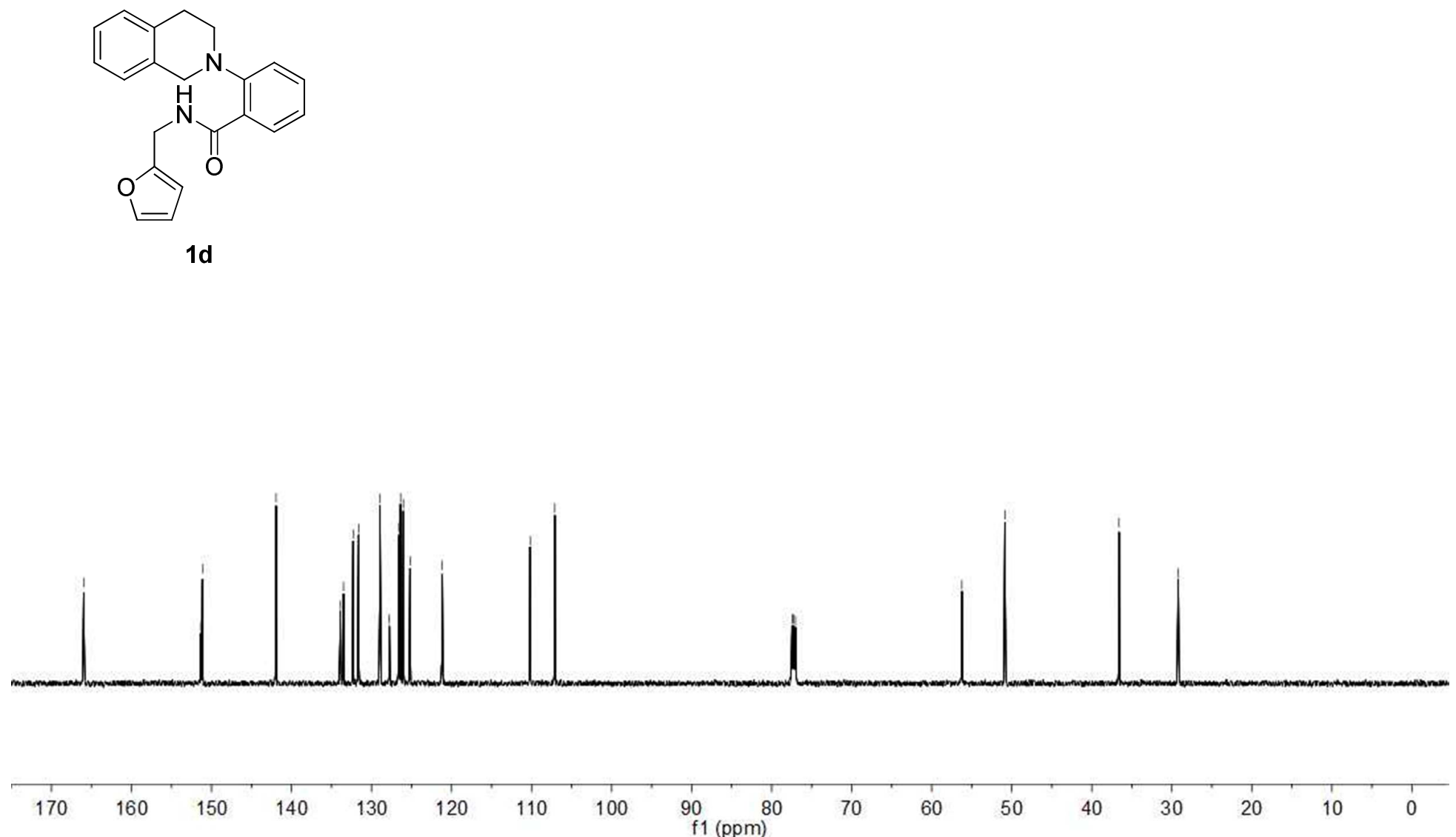

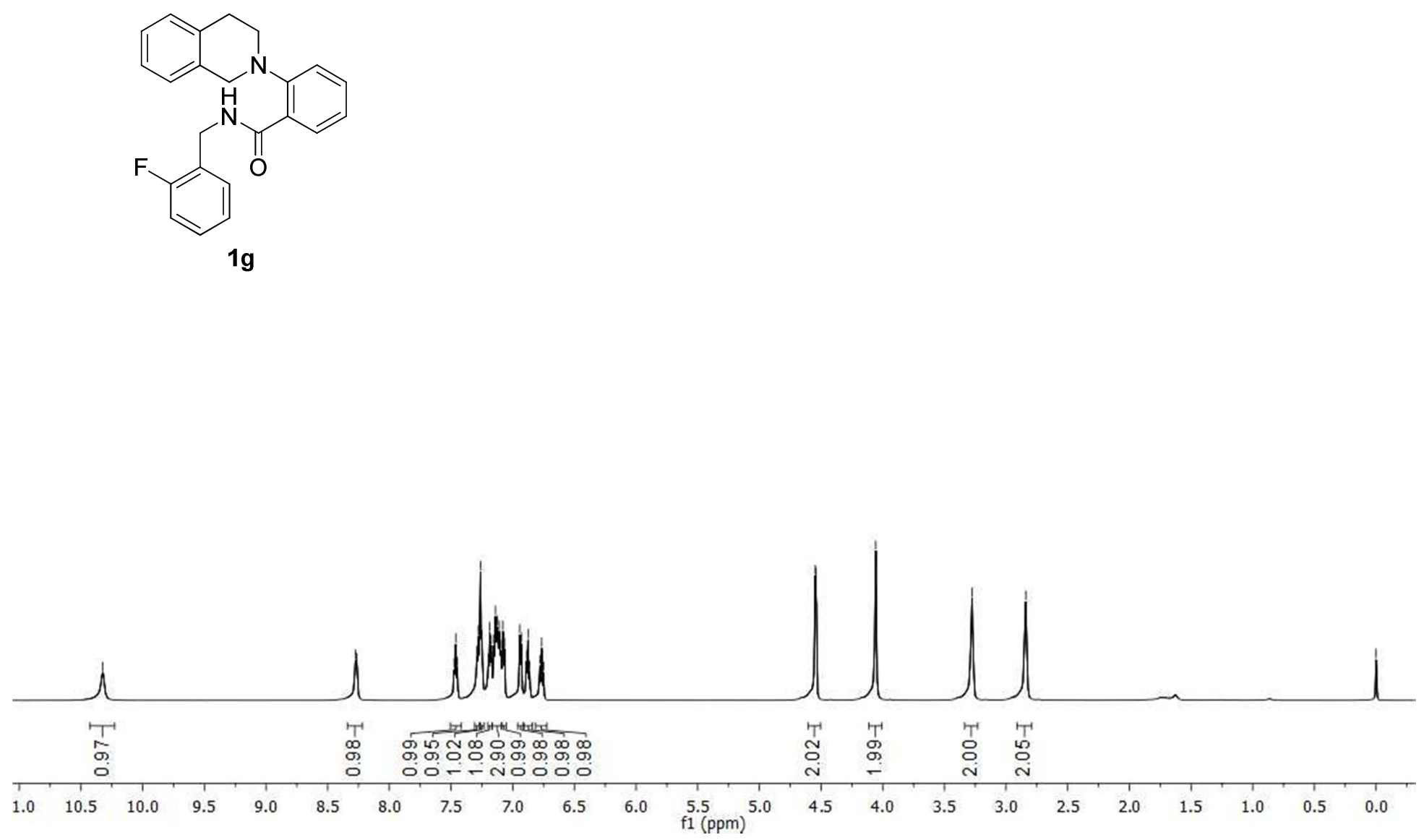


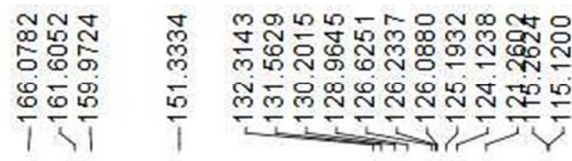

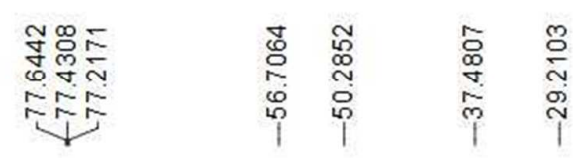

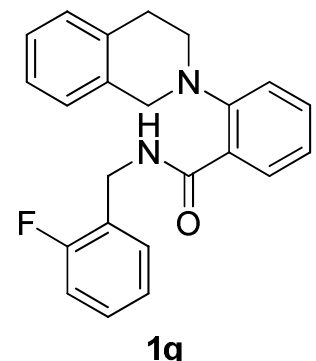

$\mid$

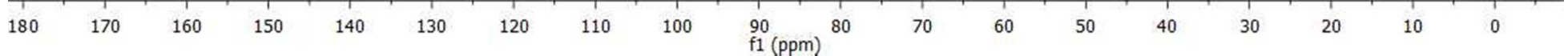


<smiles>O=C(NCCc1ccccc1)c1ccccc1N1CCc2ccccc2C1</smiles>

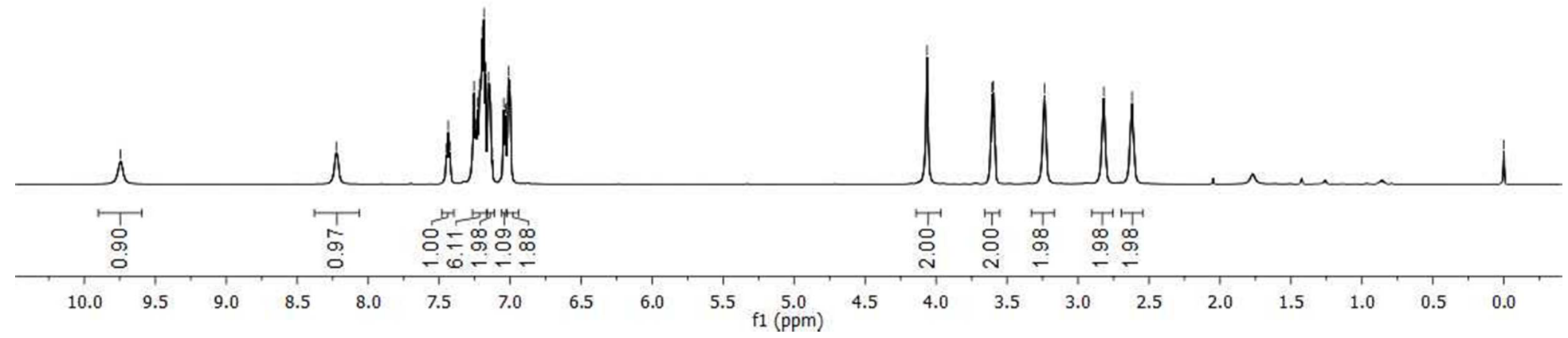


荡

:

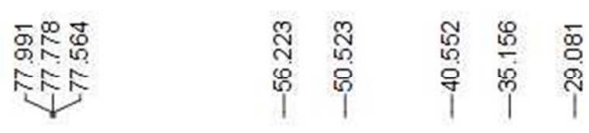
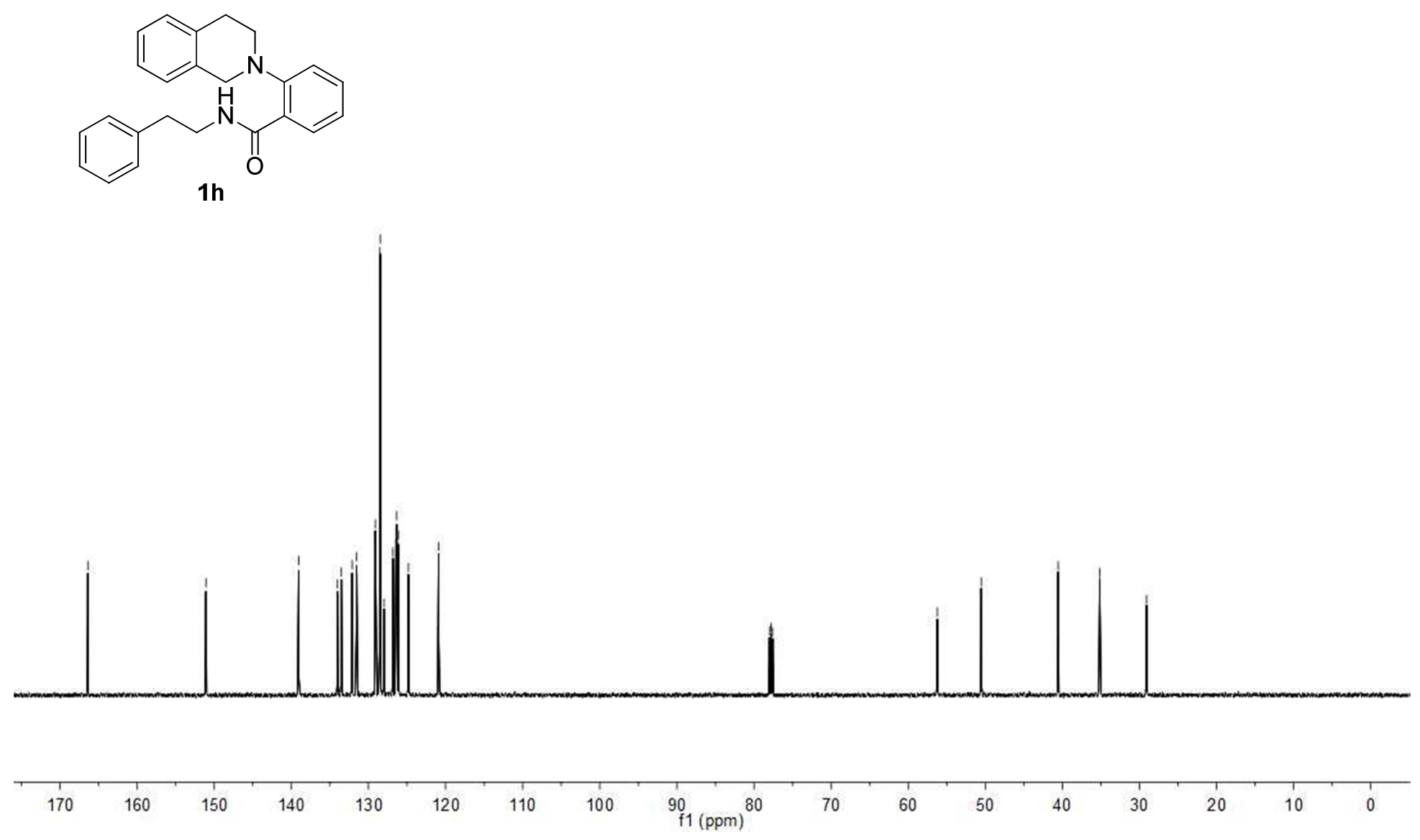

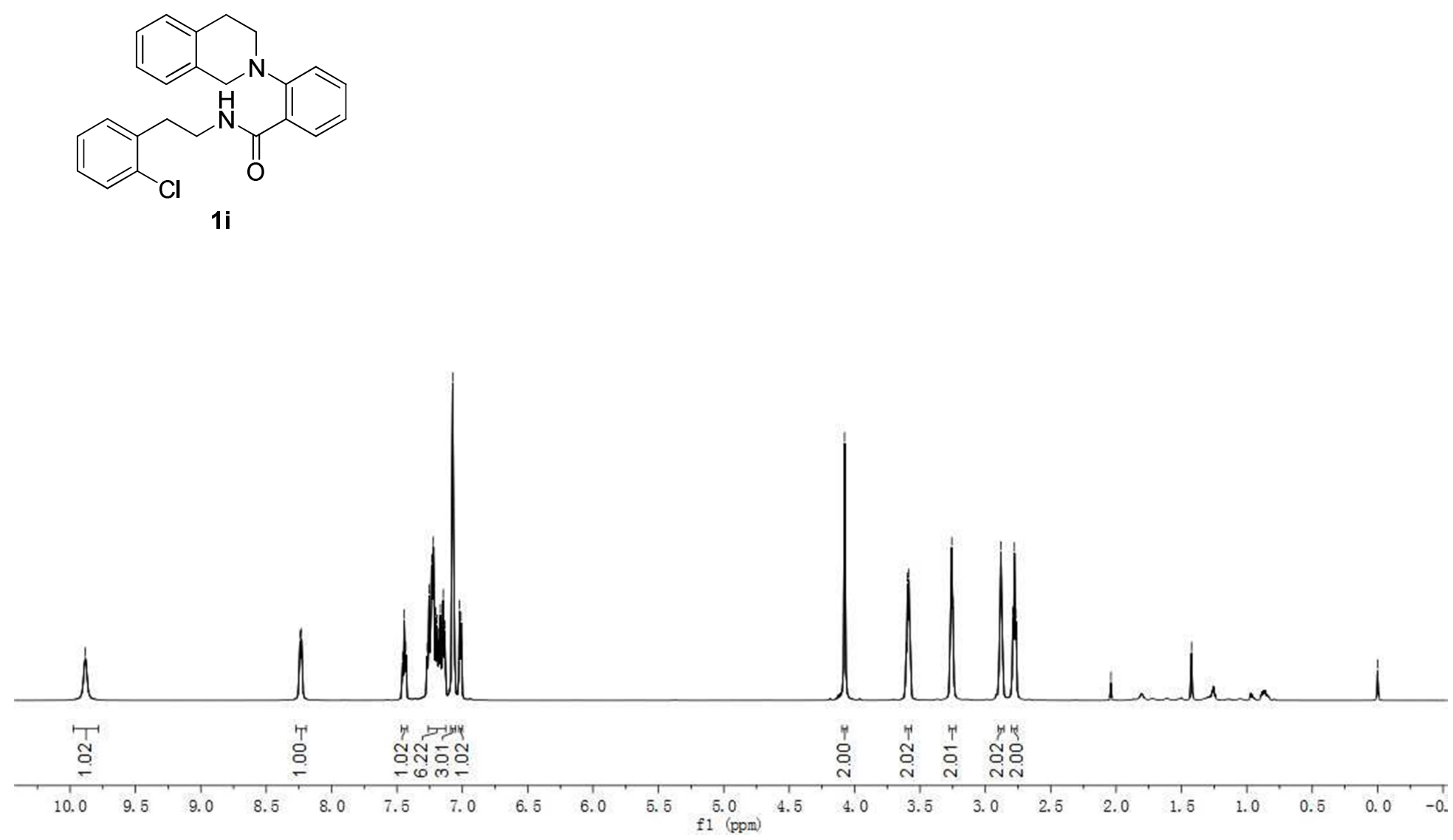

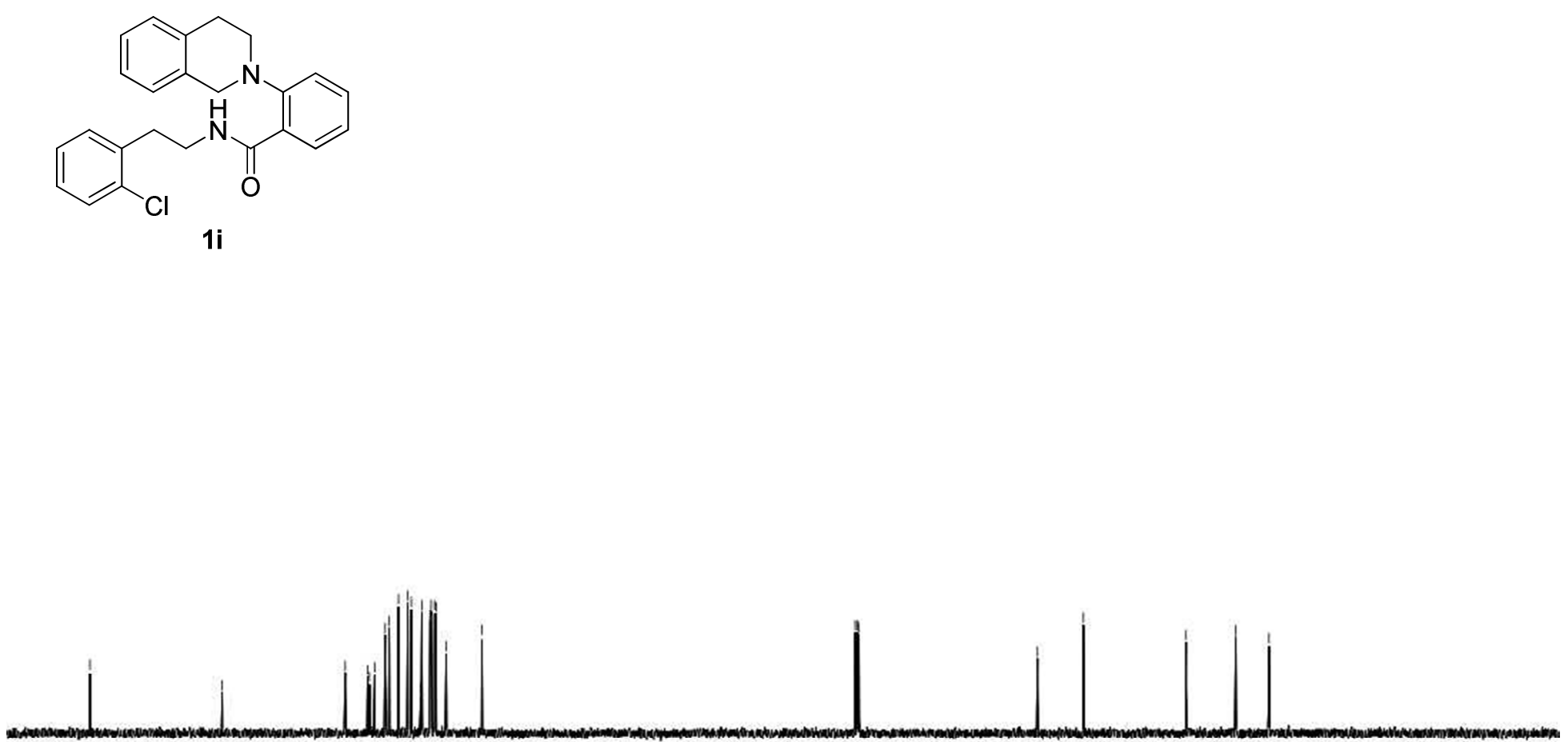

$$
170
$$



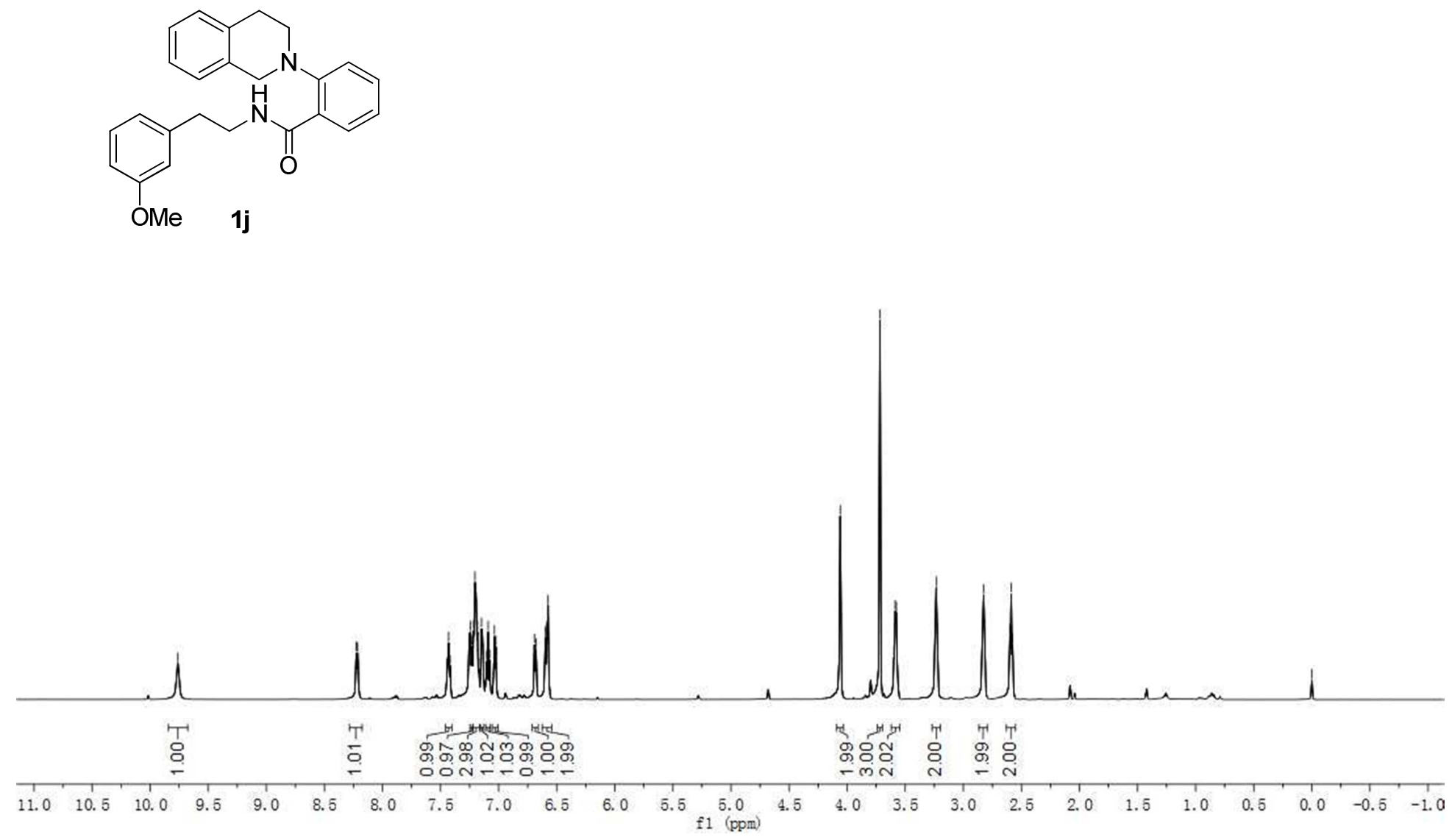


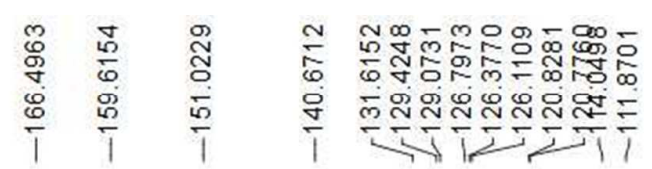

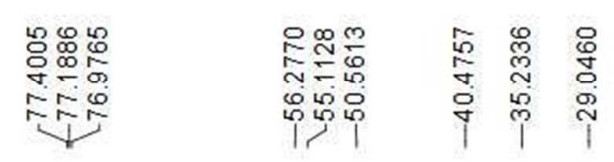
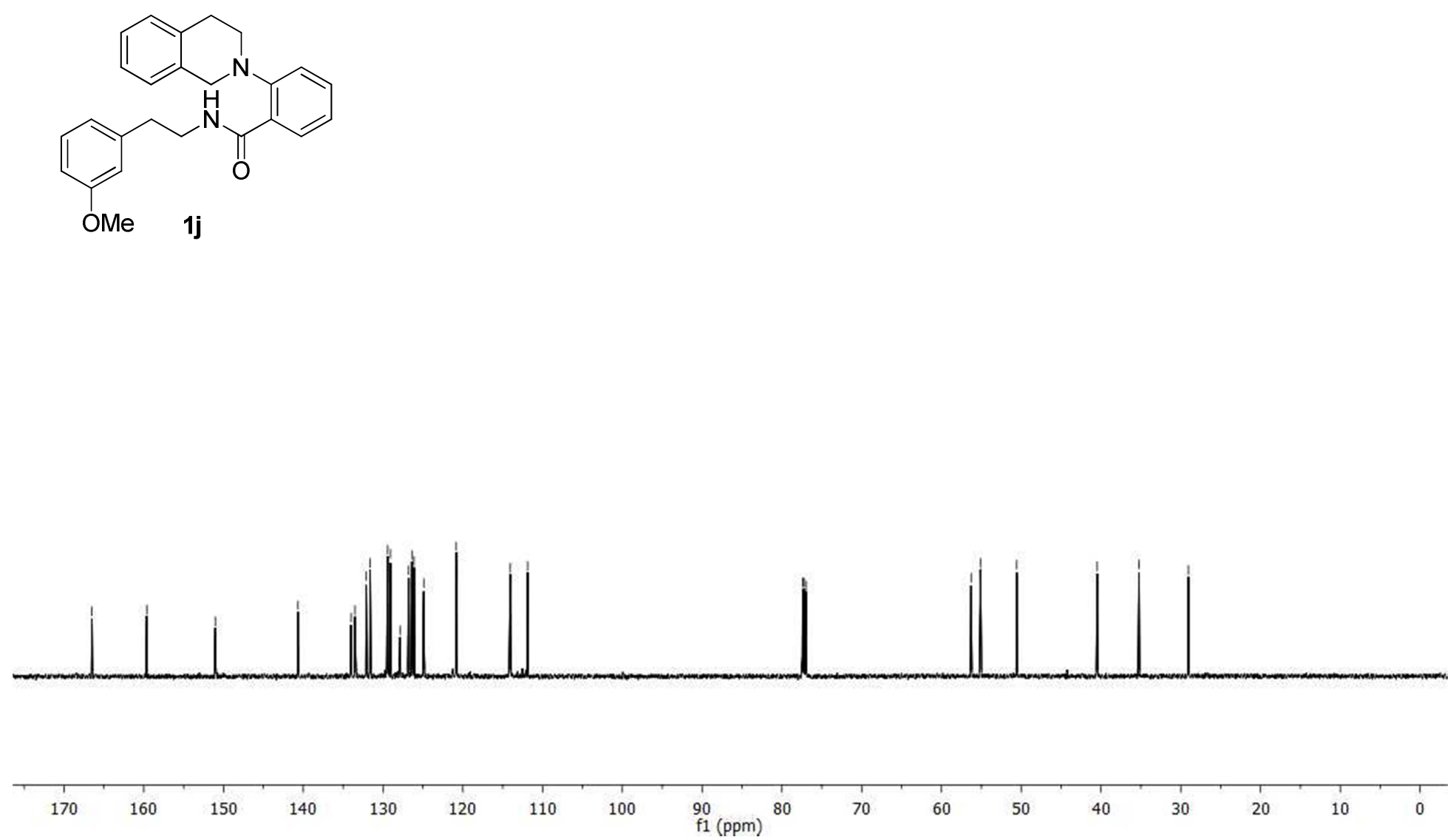

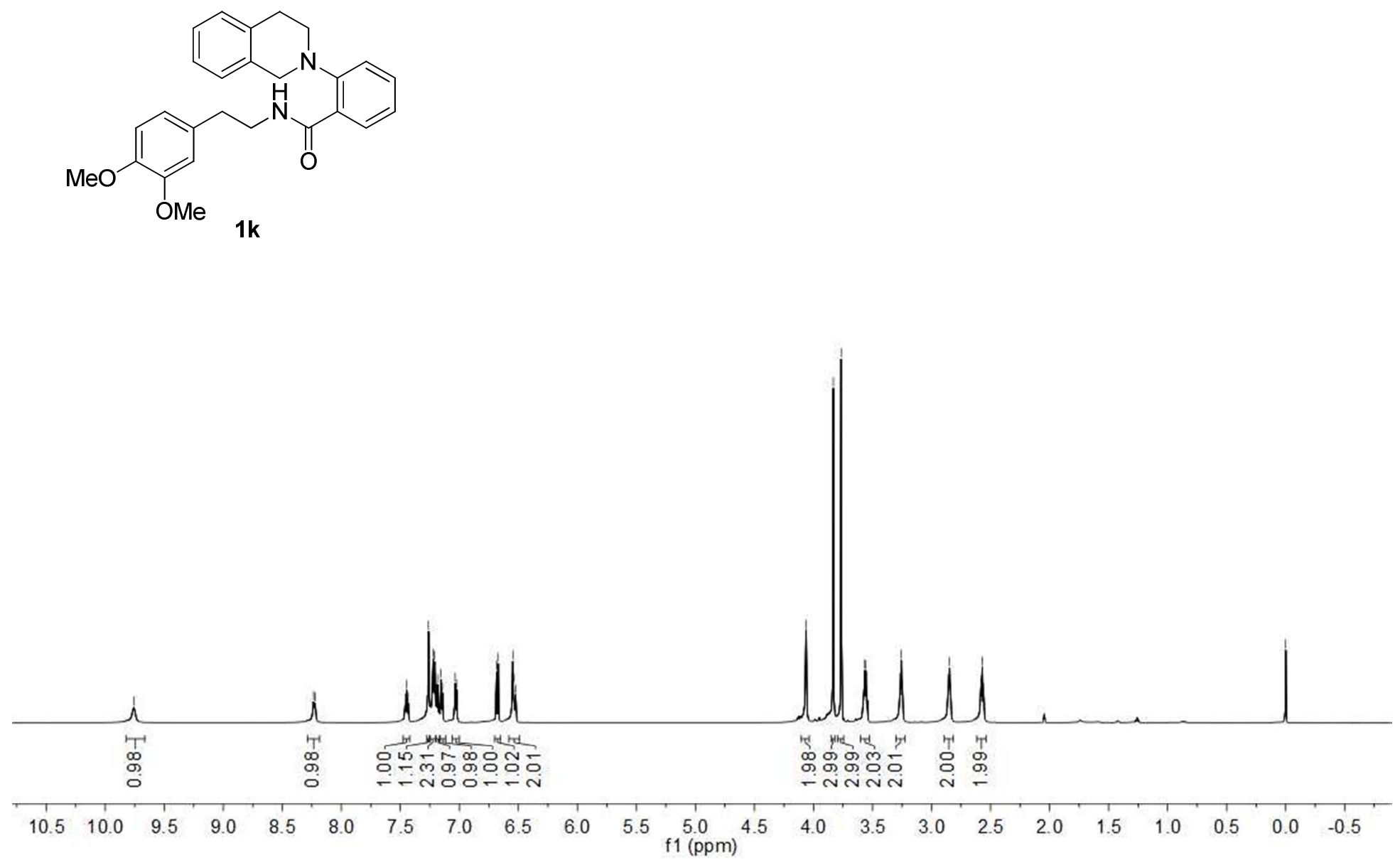

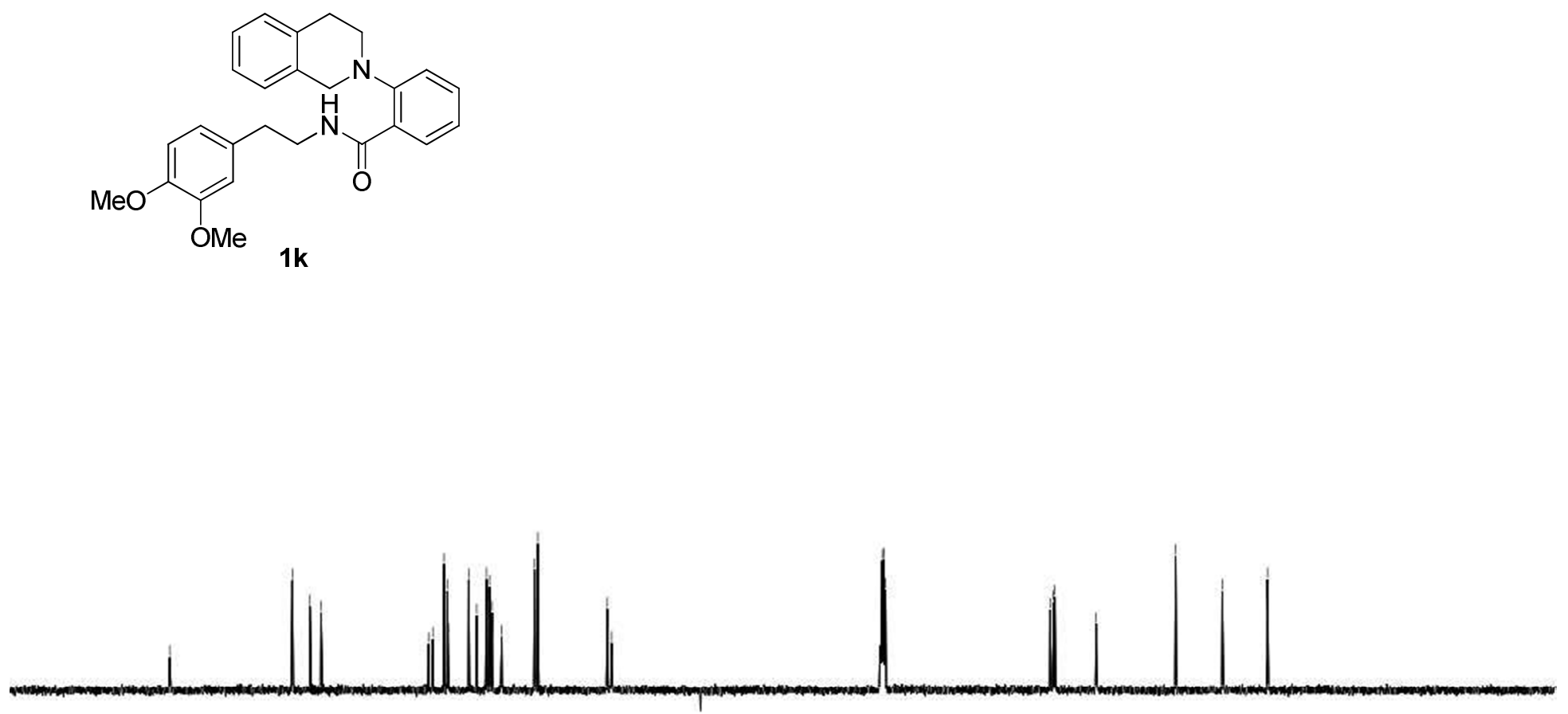

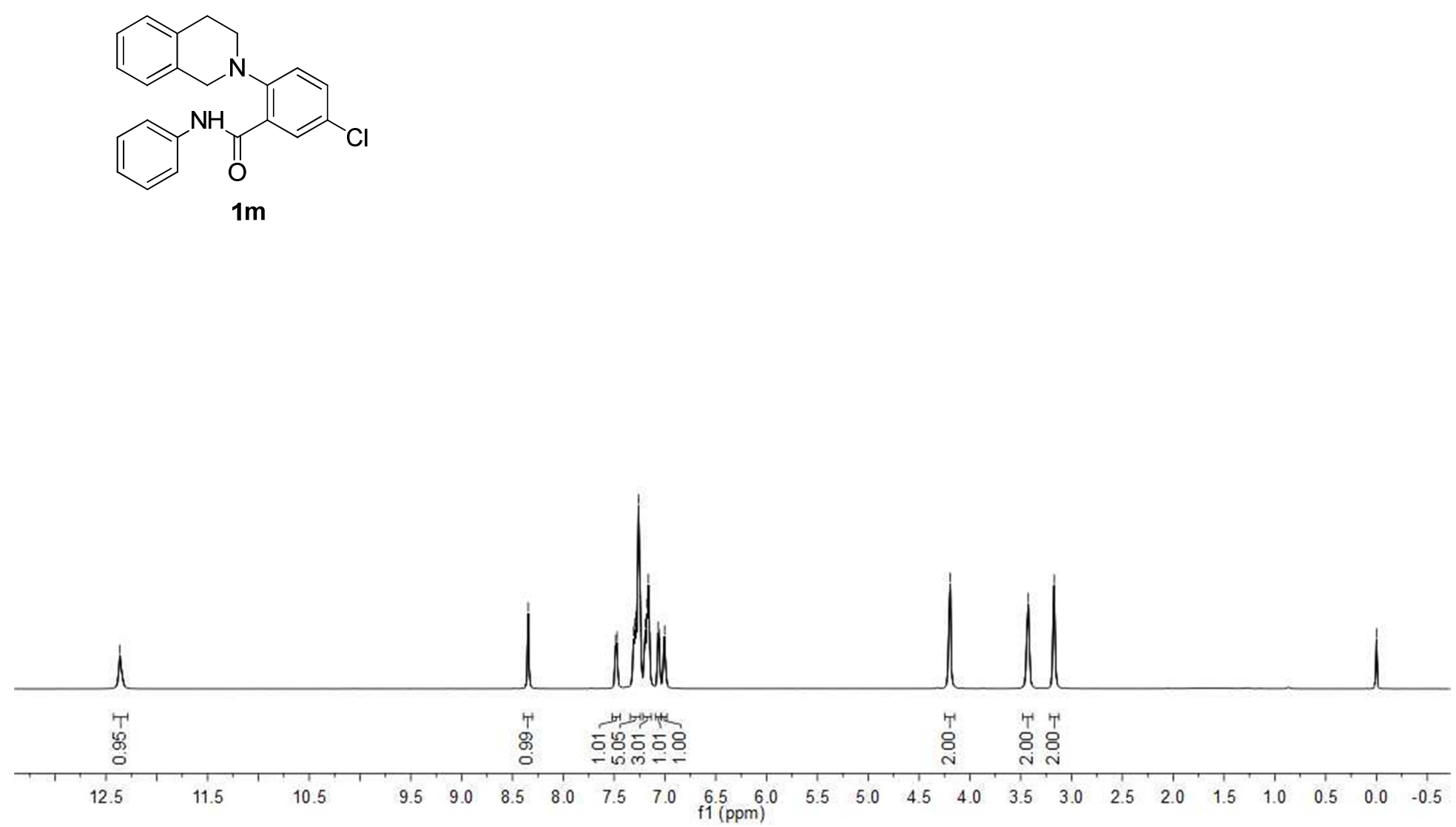

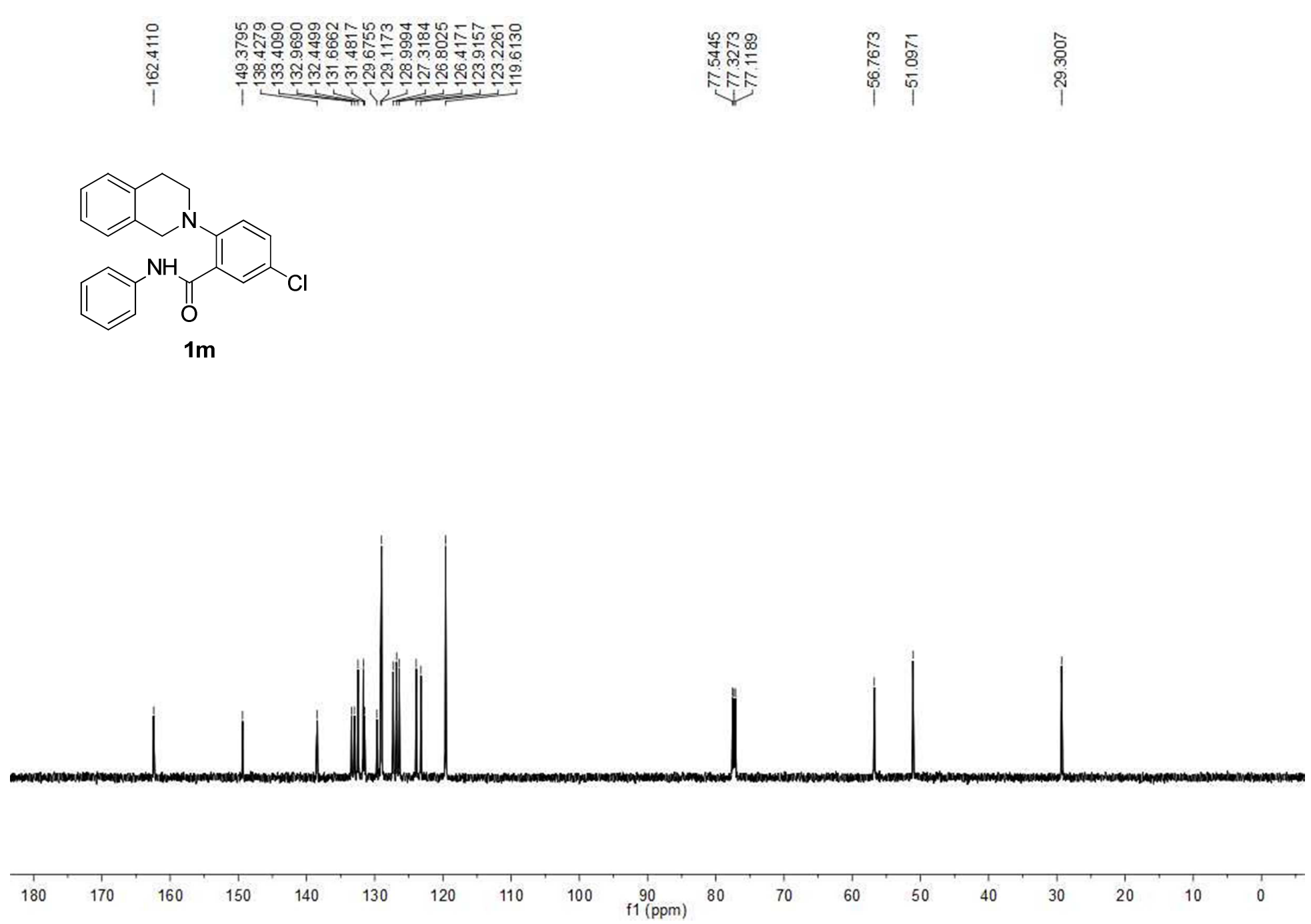

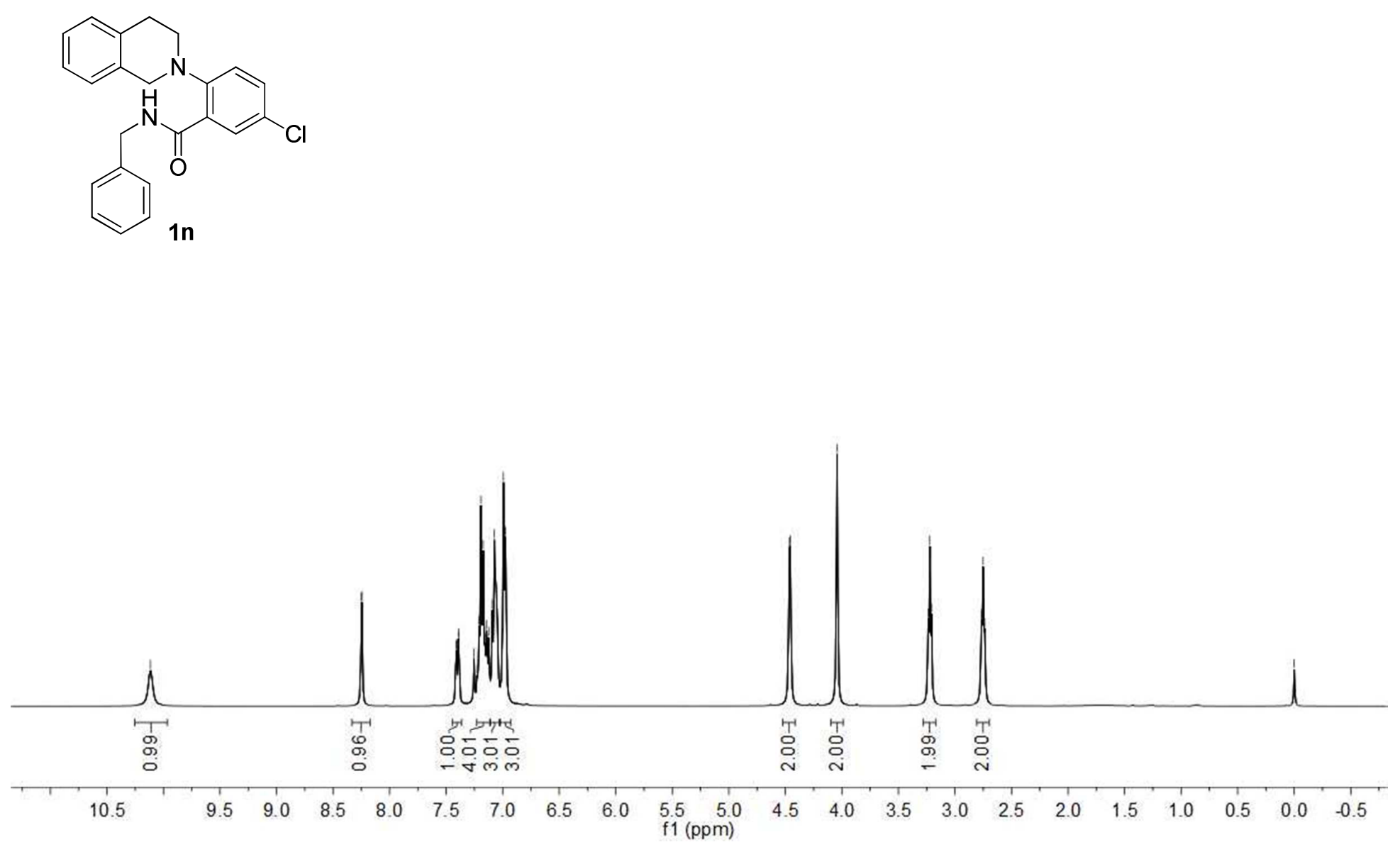

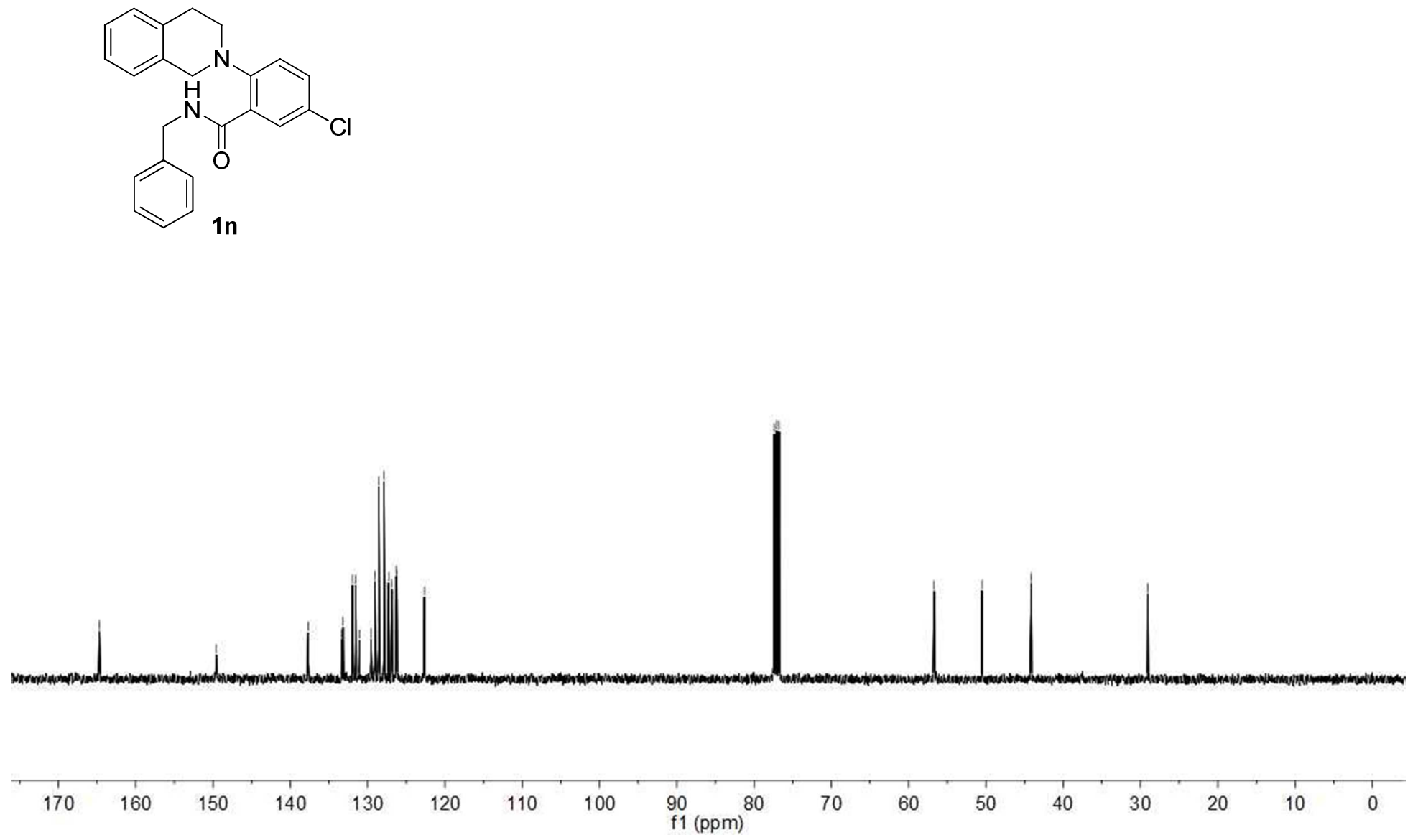

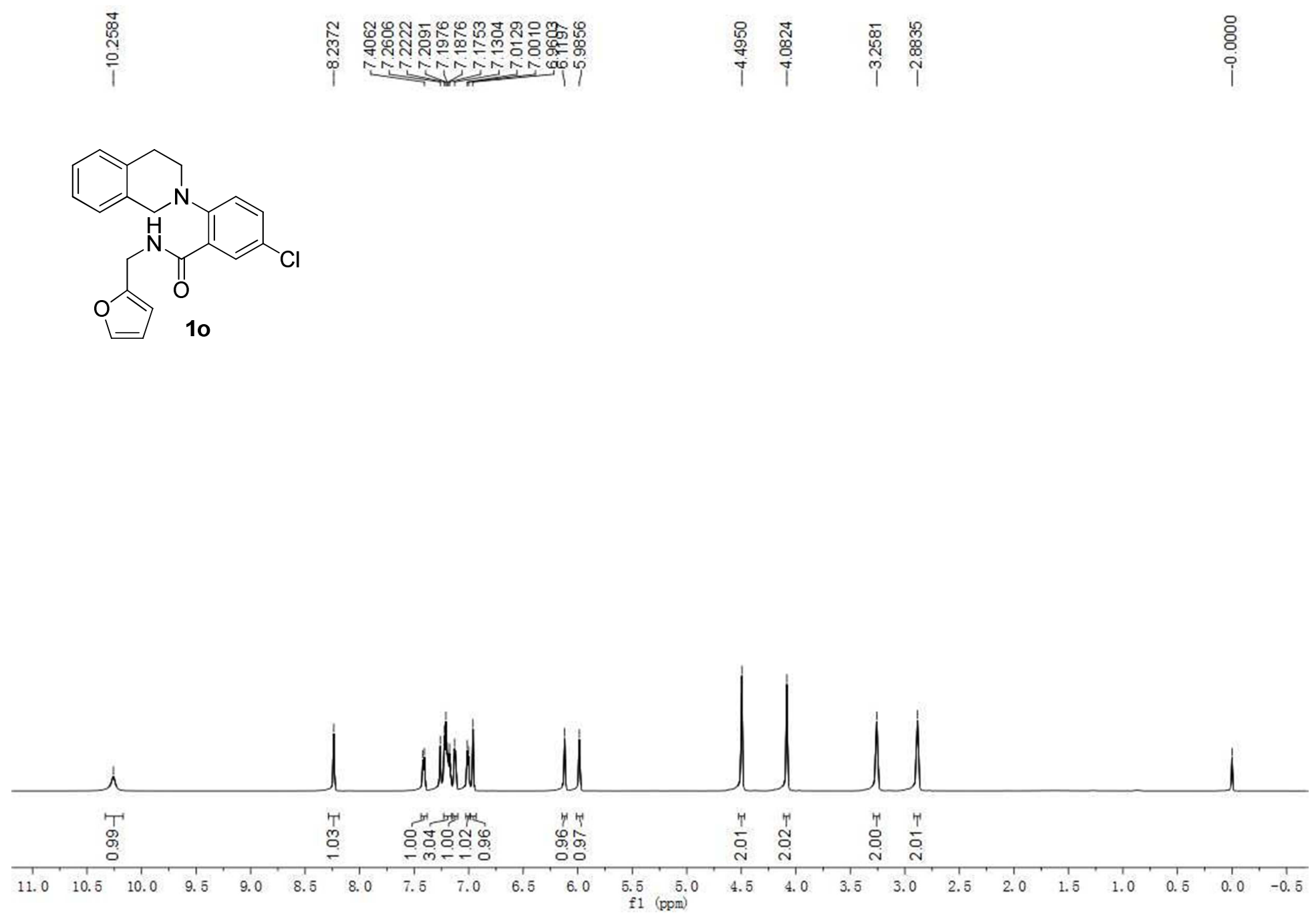

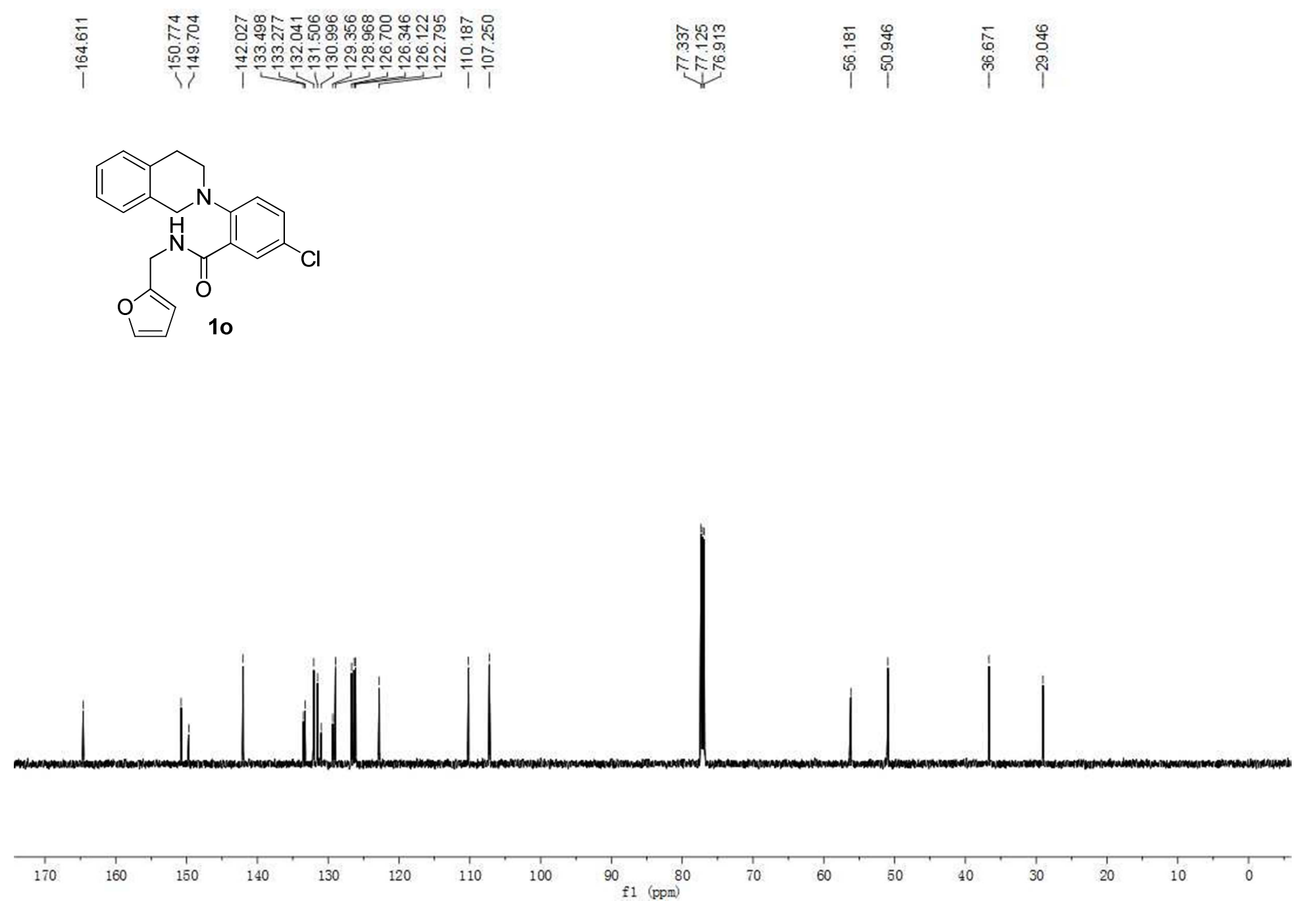


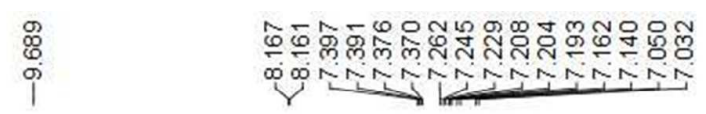

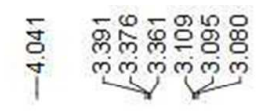

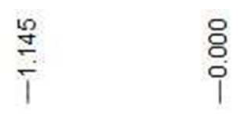
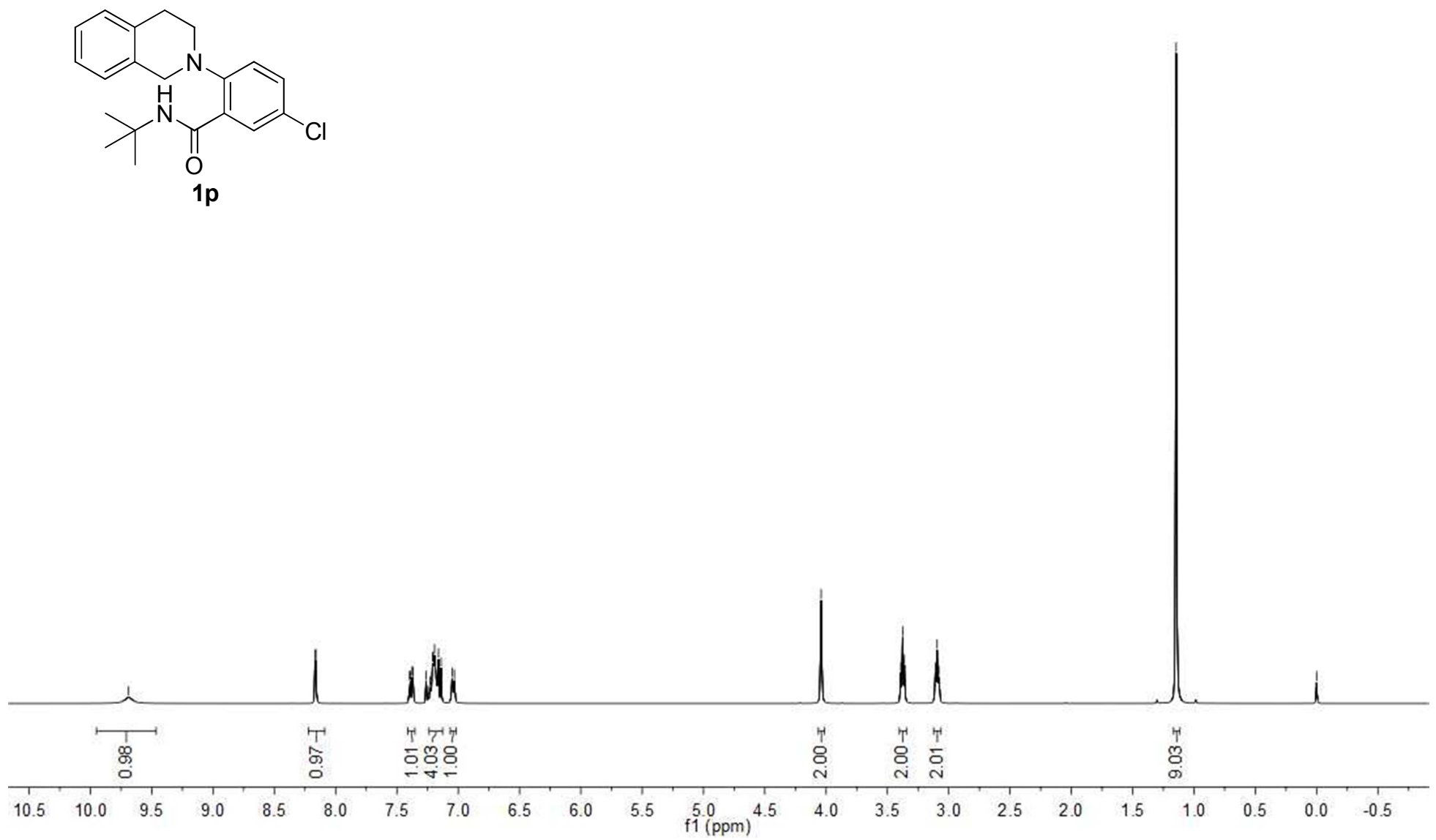

S22 

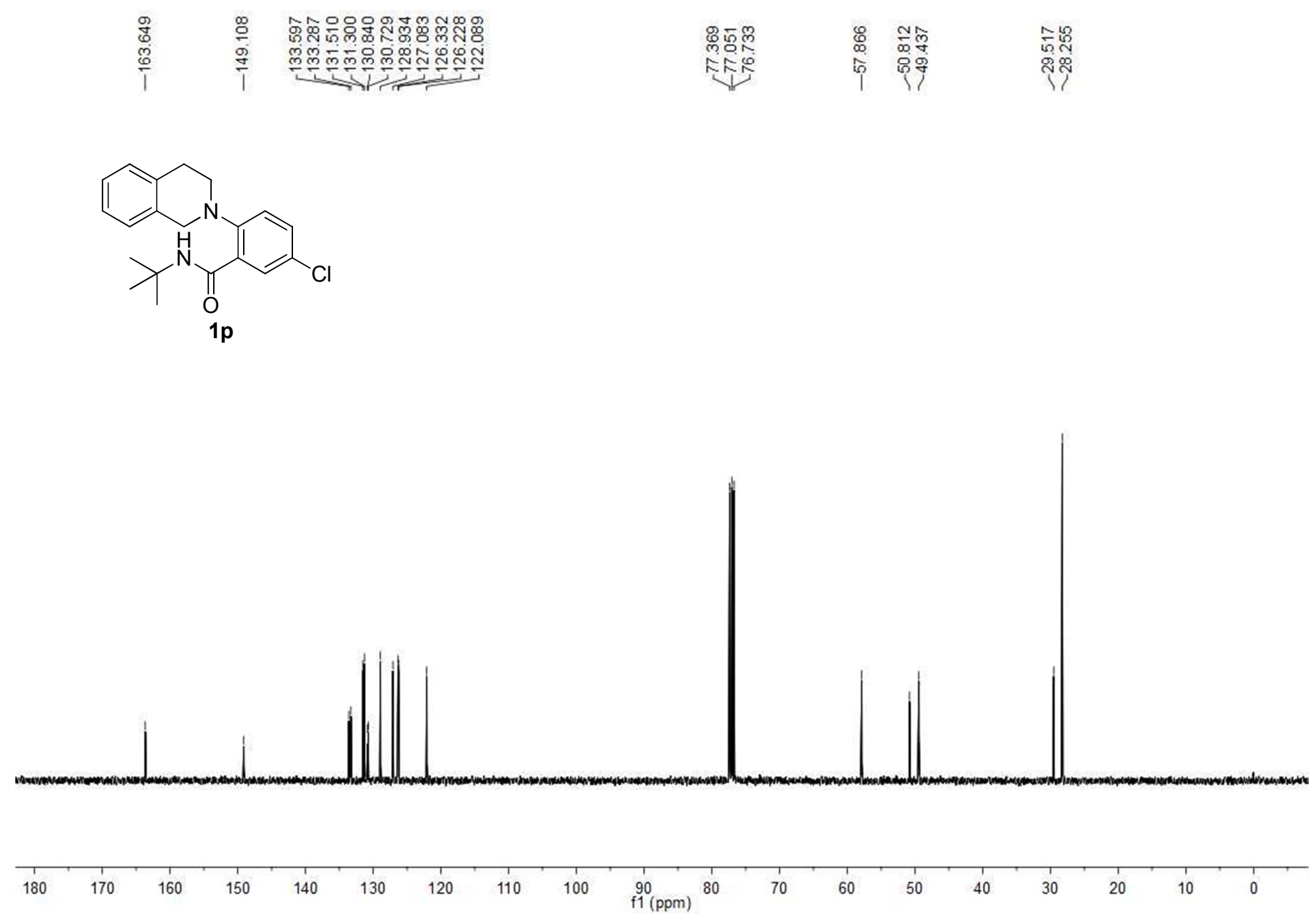

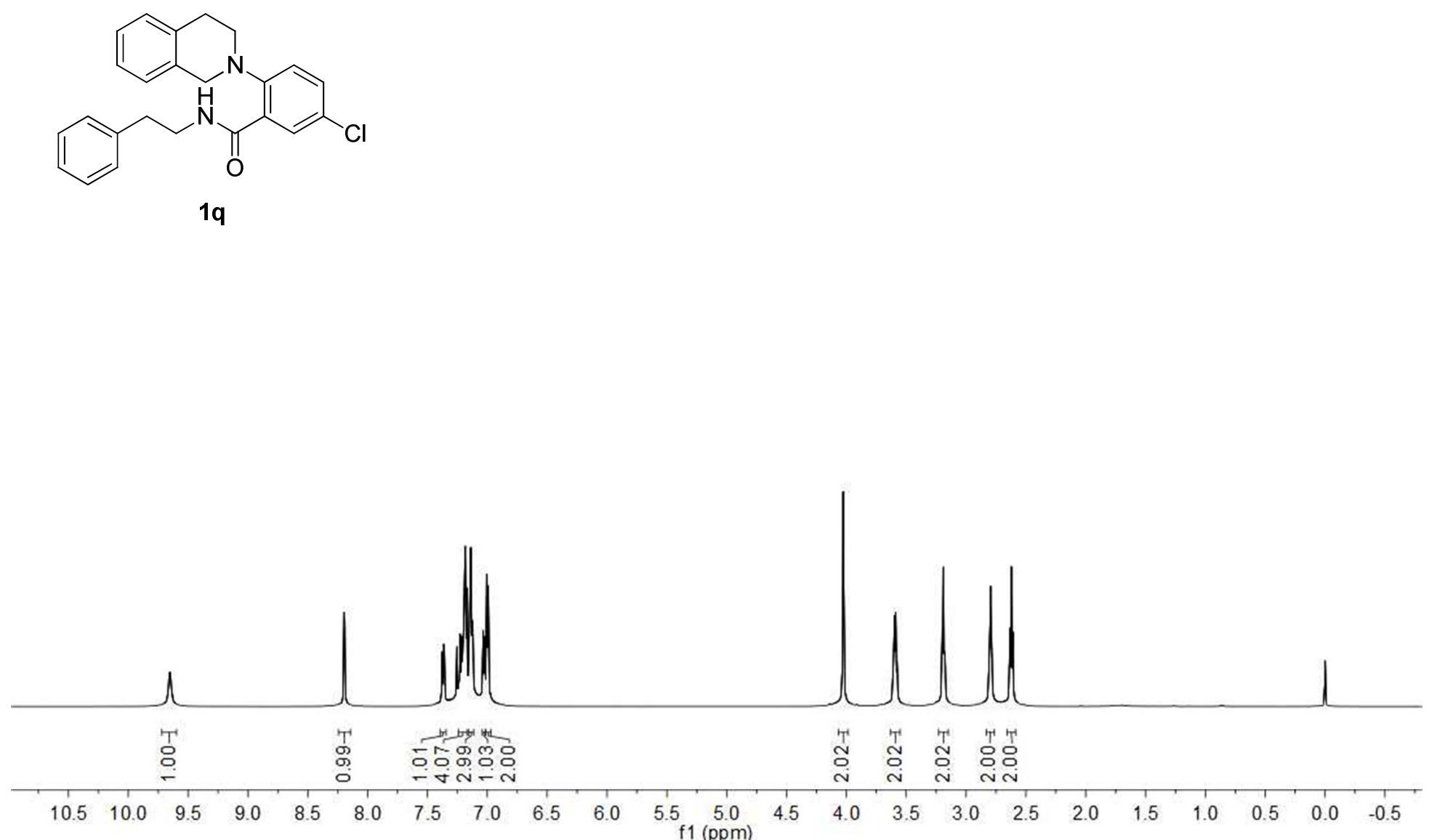


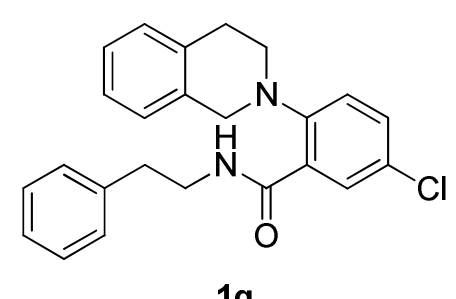

$1 q$

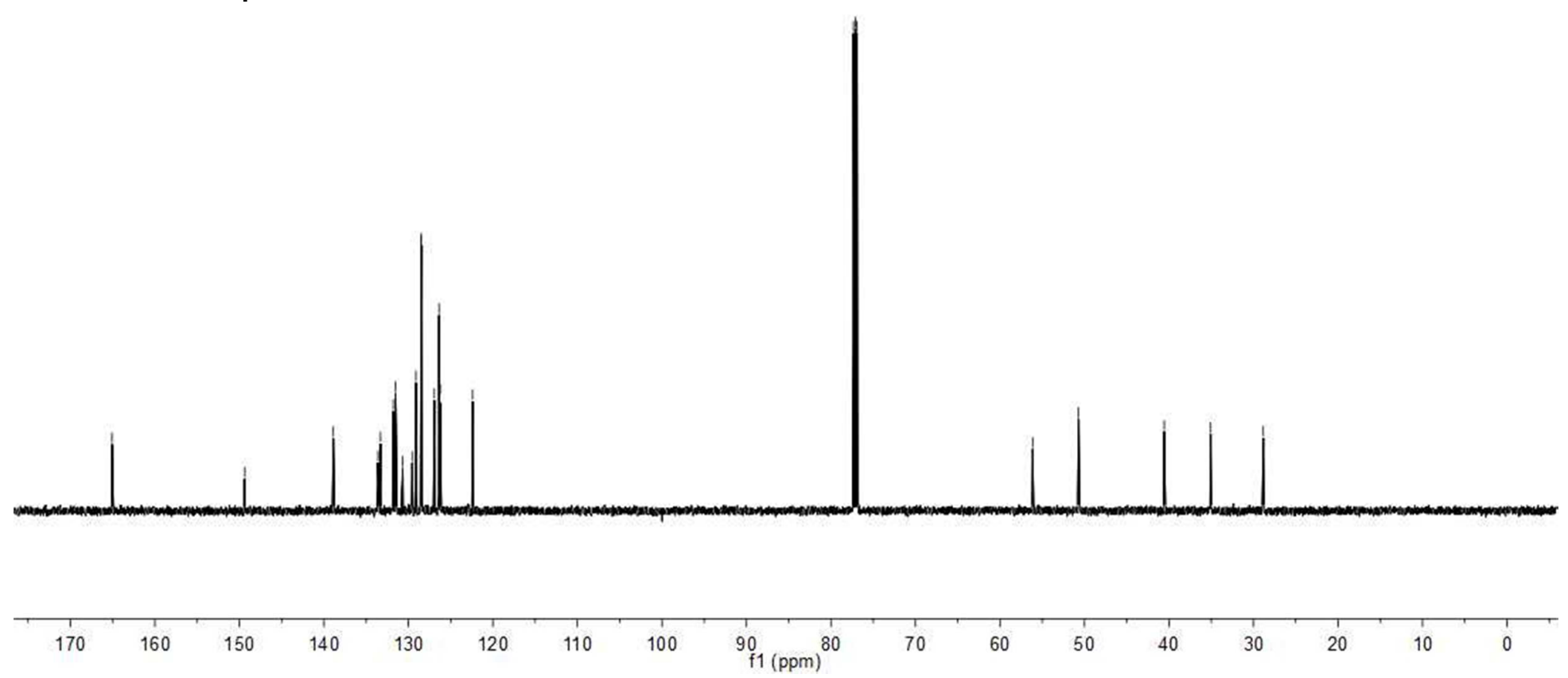



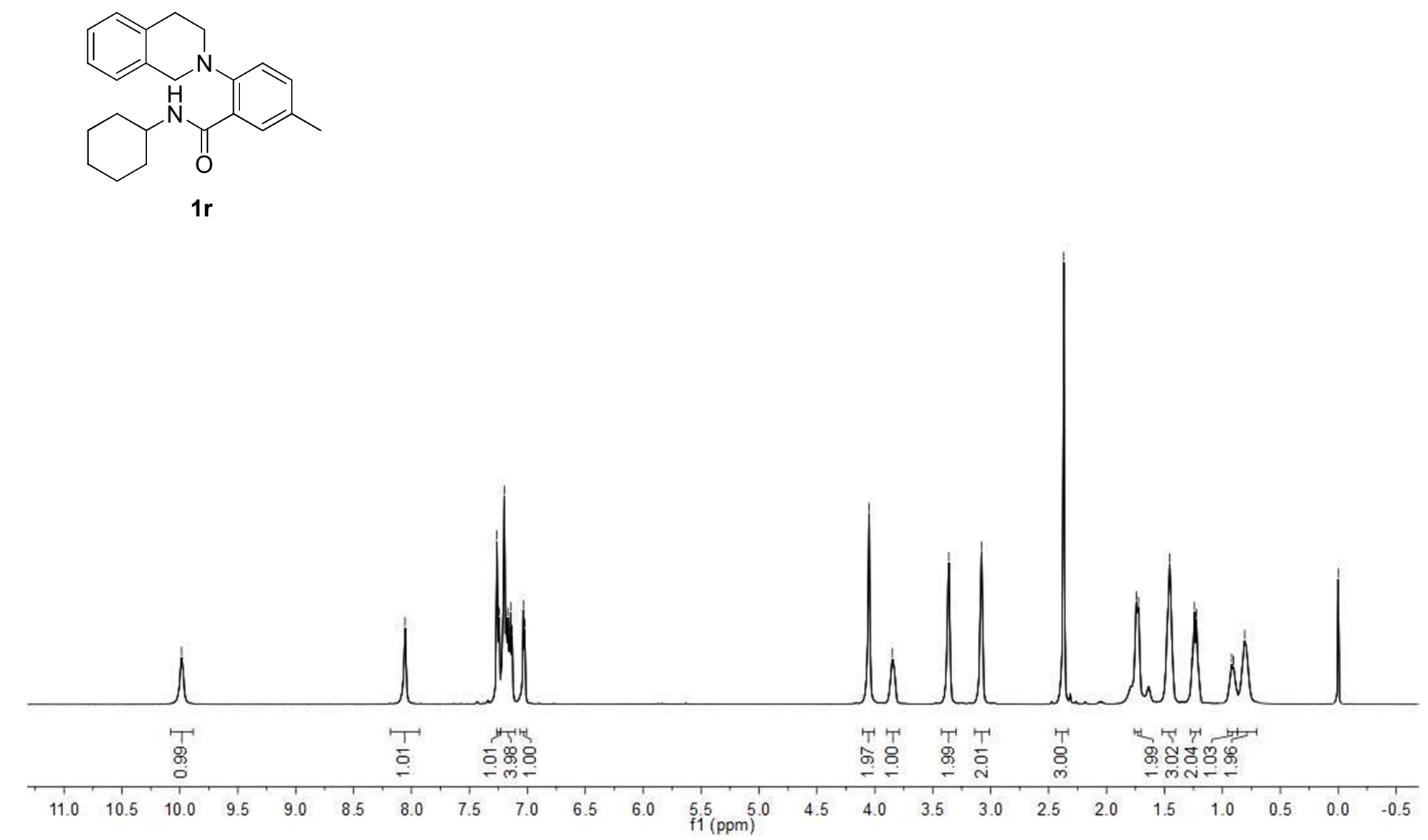

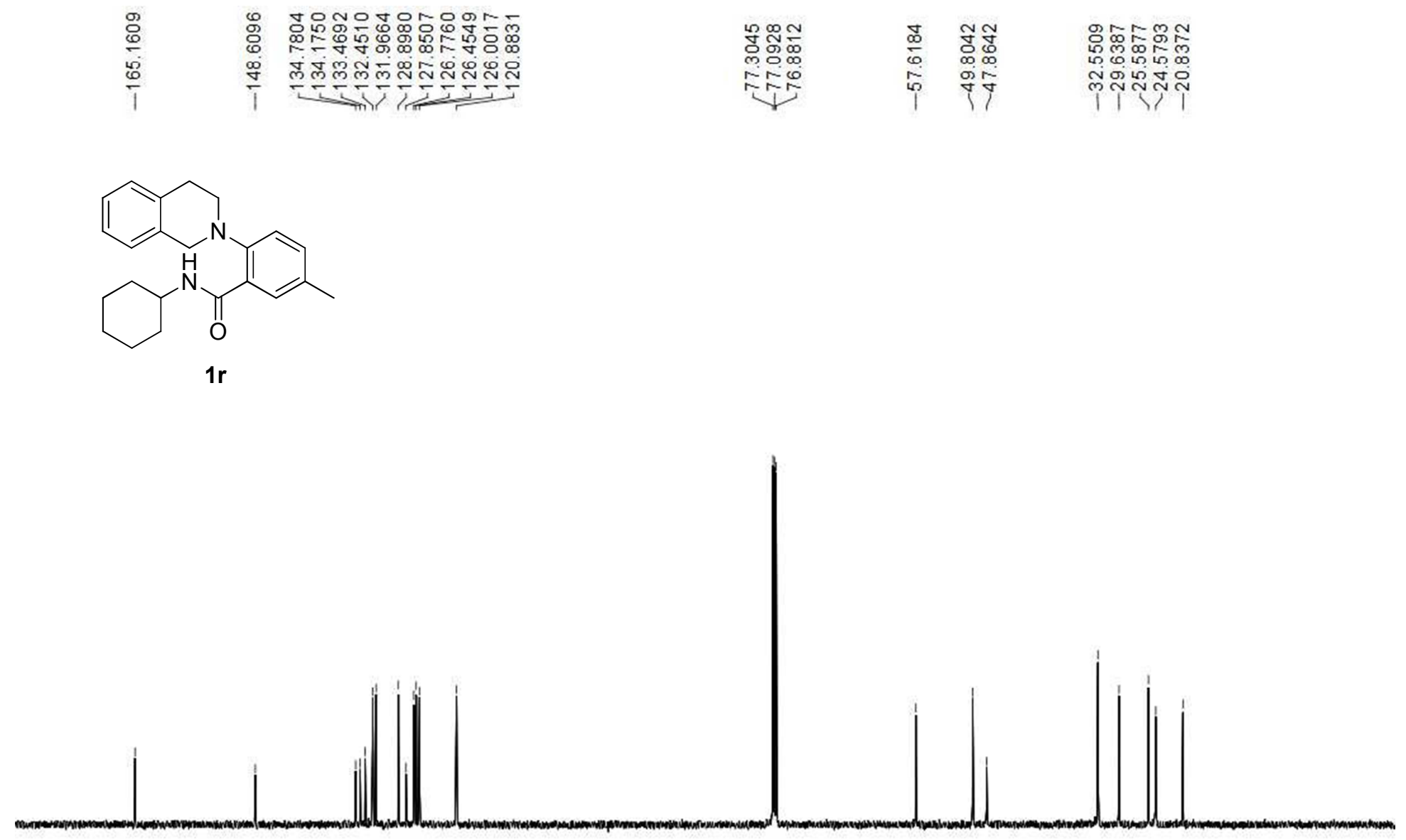

180

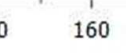

150

$40 \quad 130$

120

100

${ }^{90}{ }^{80 p m)}$ 


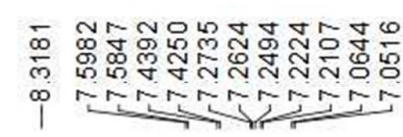

$$
\text { 芩 }
$$
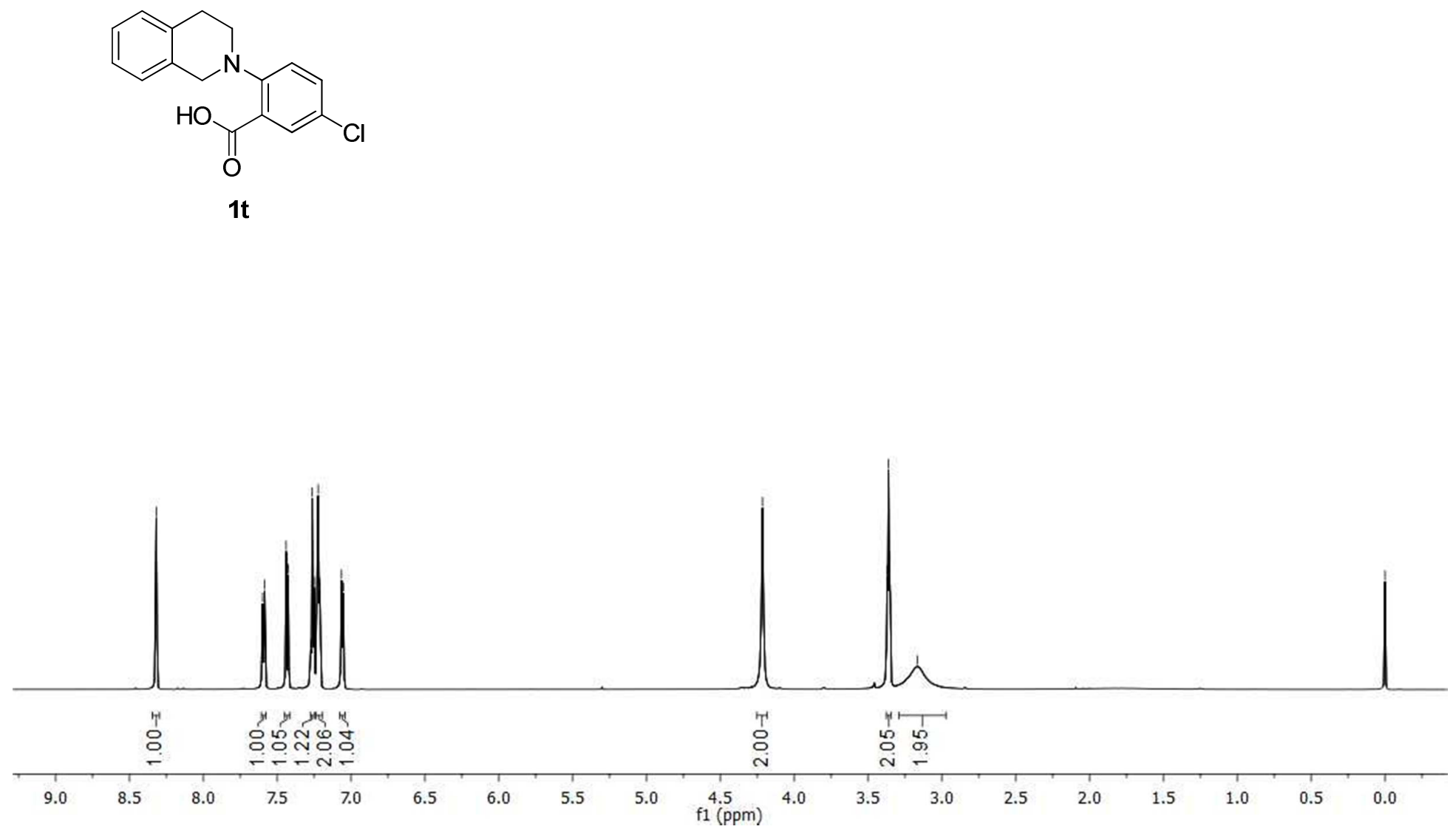


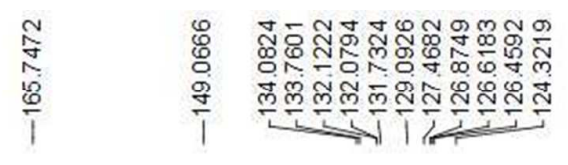

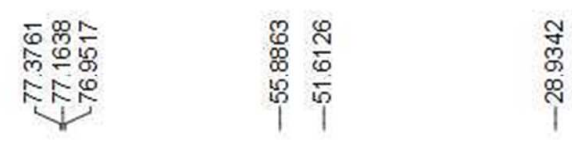
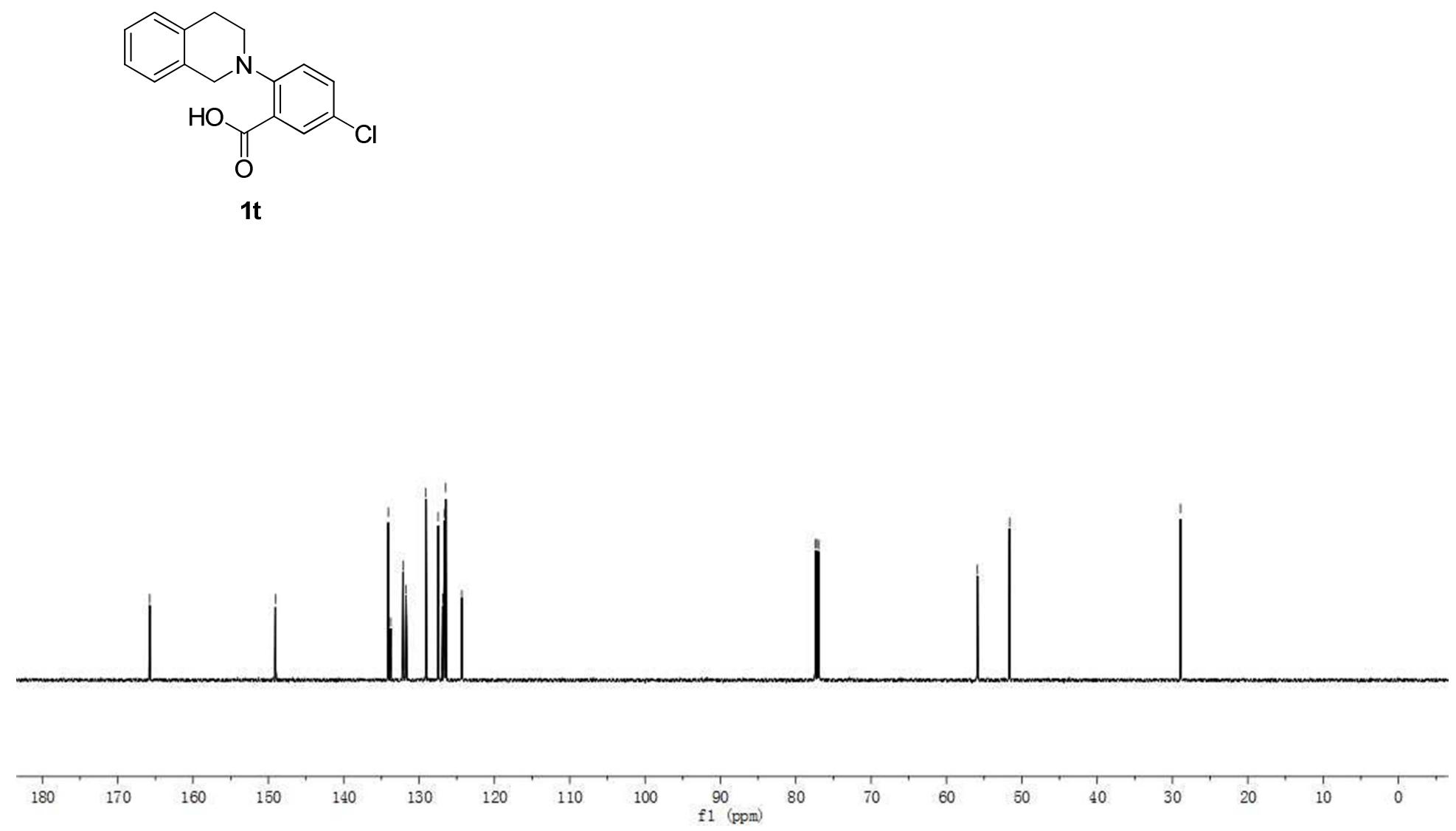

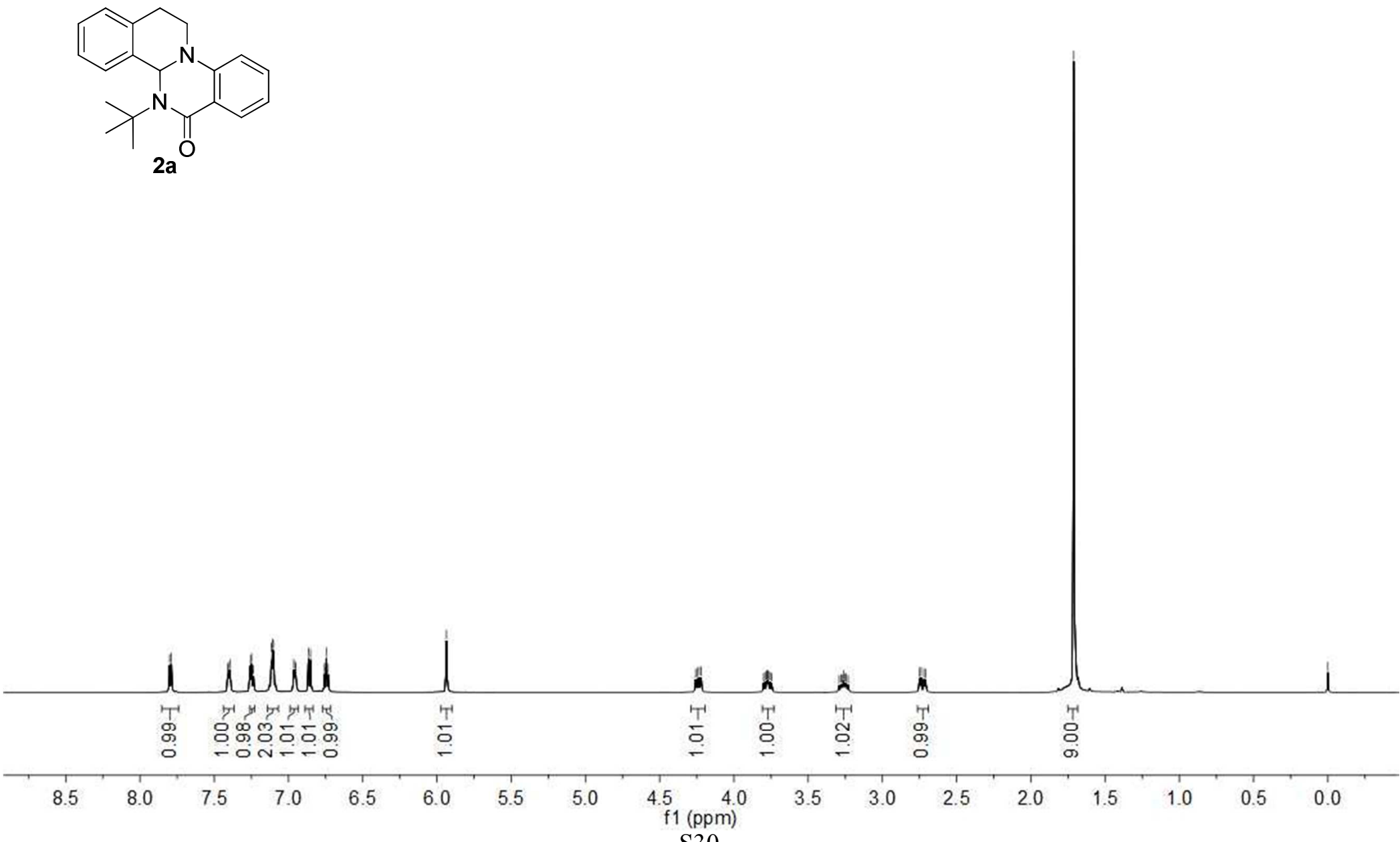


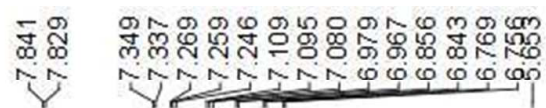

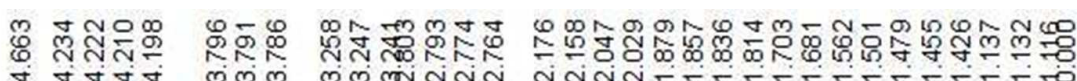

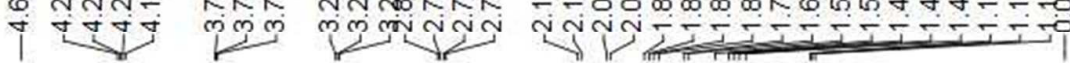
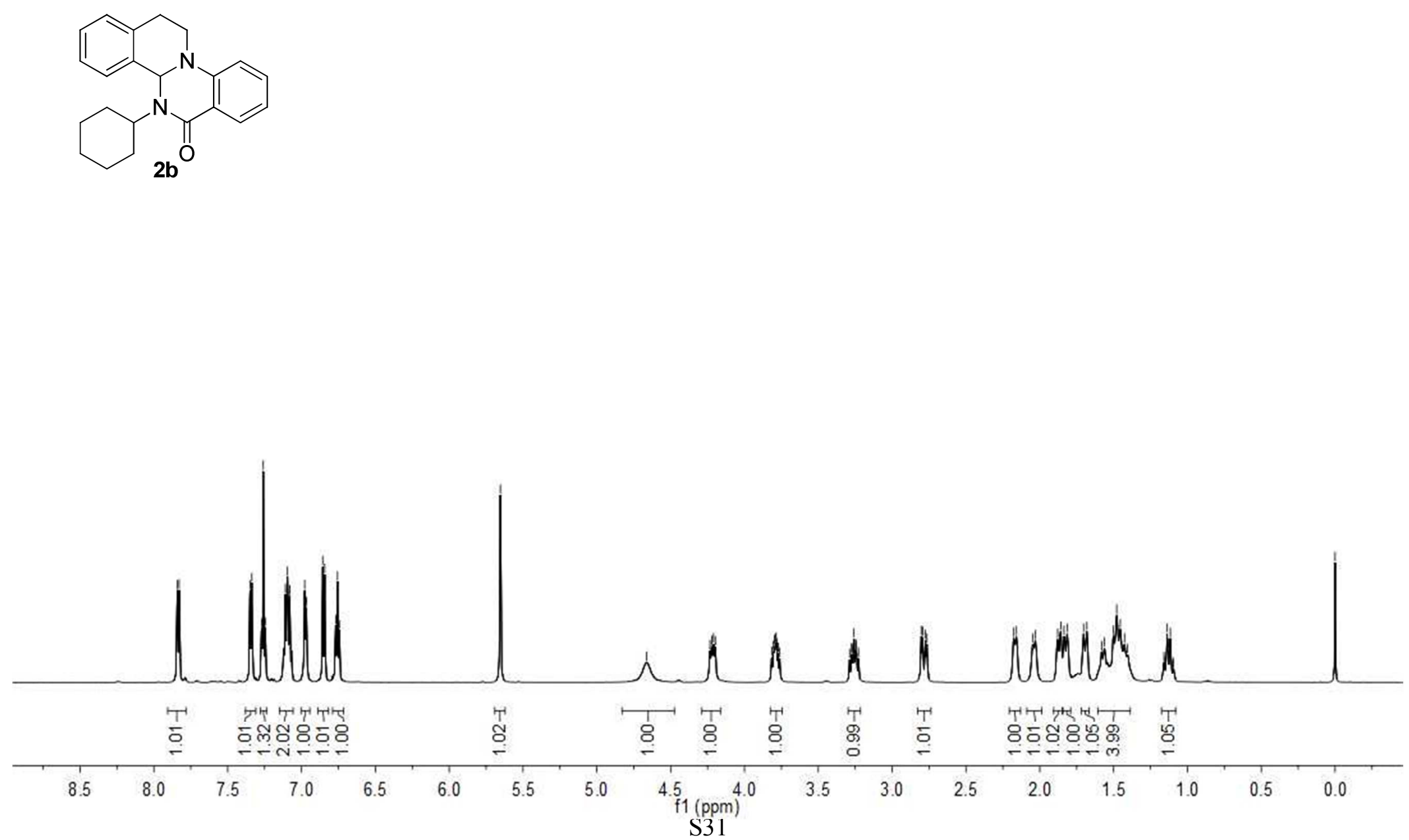

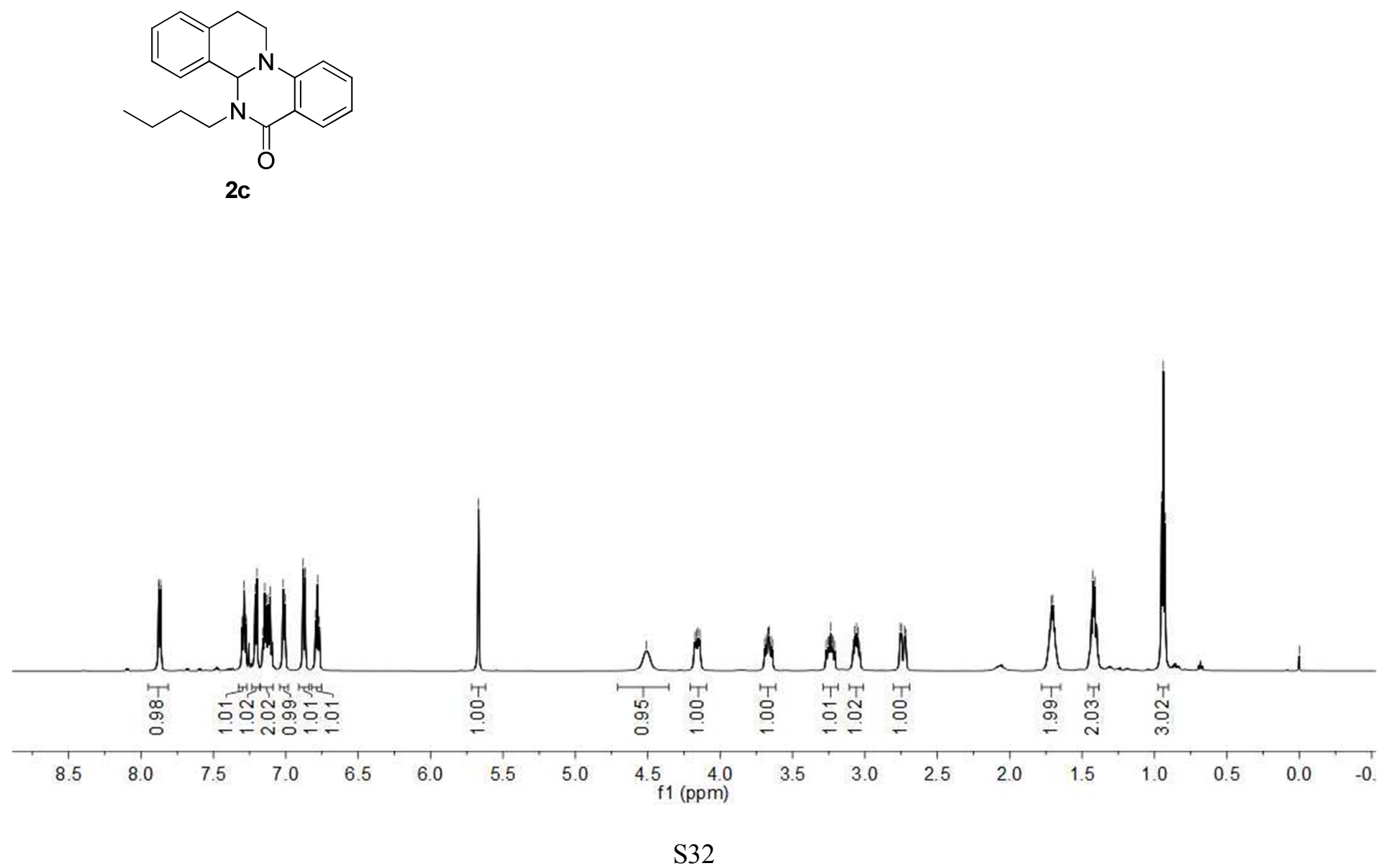


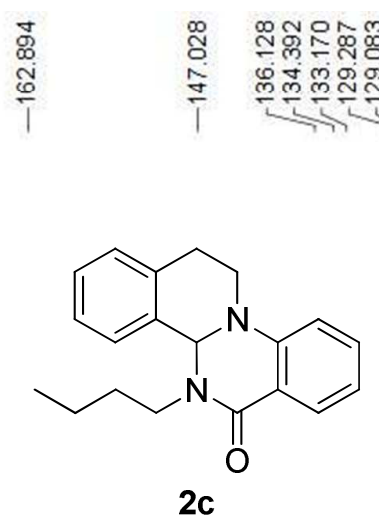

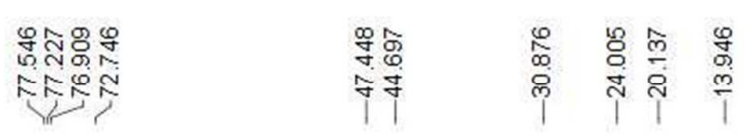

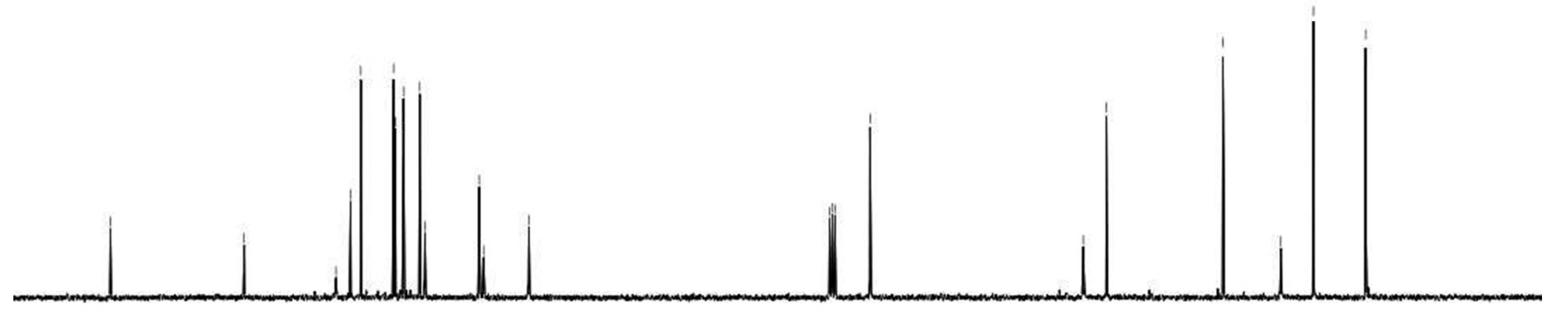

$170 \quad 160$

120

$110 \quad 100 \quad 90 \quad \begin{array}{r}80 \\ \mathrm{f} 1(\mathrm{ppm})\end{array}$ 


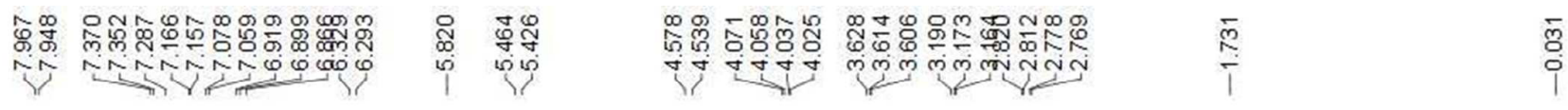
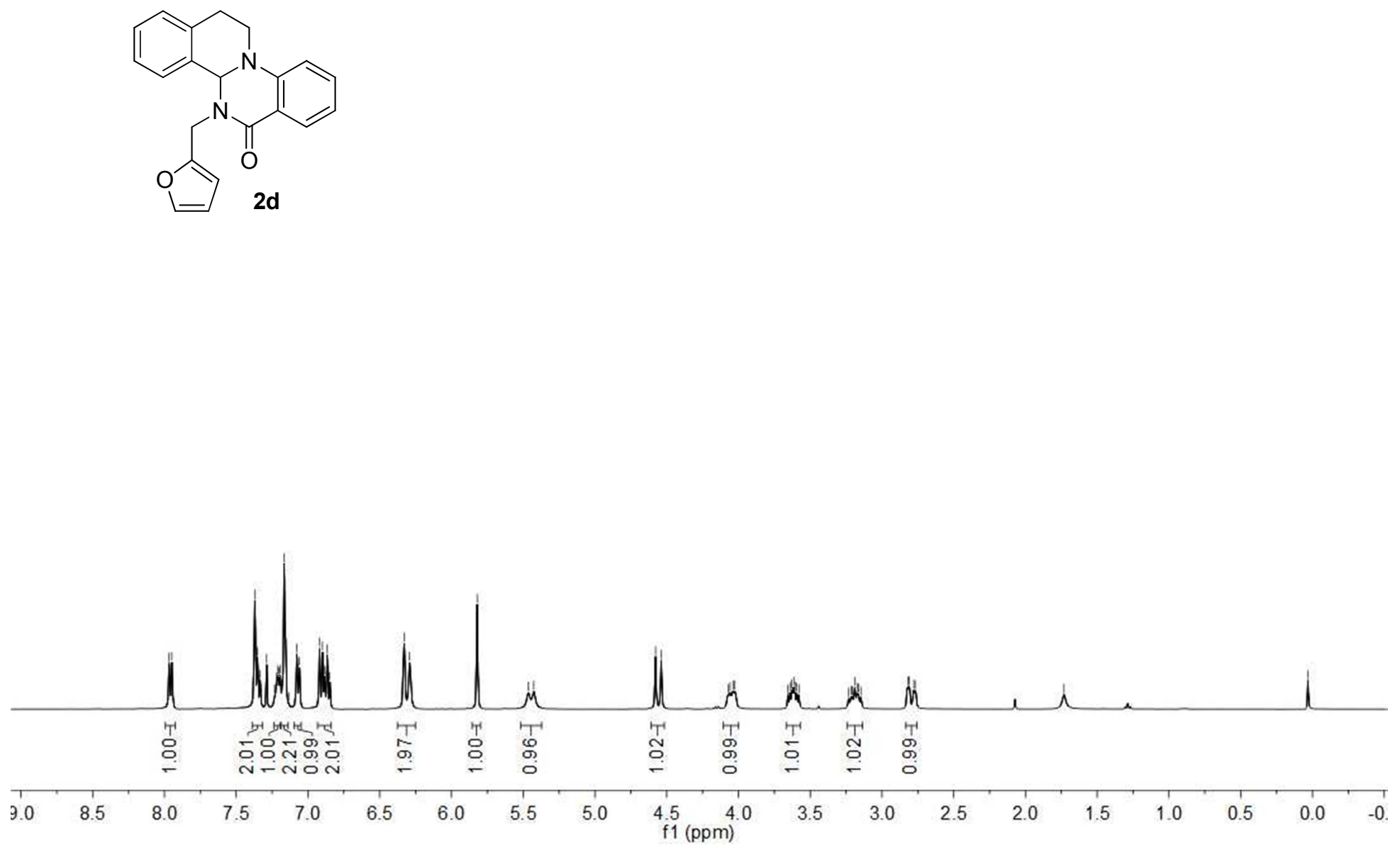

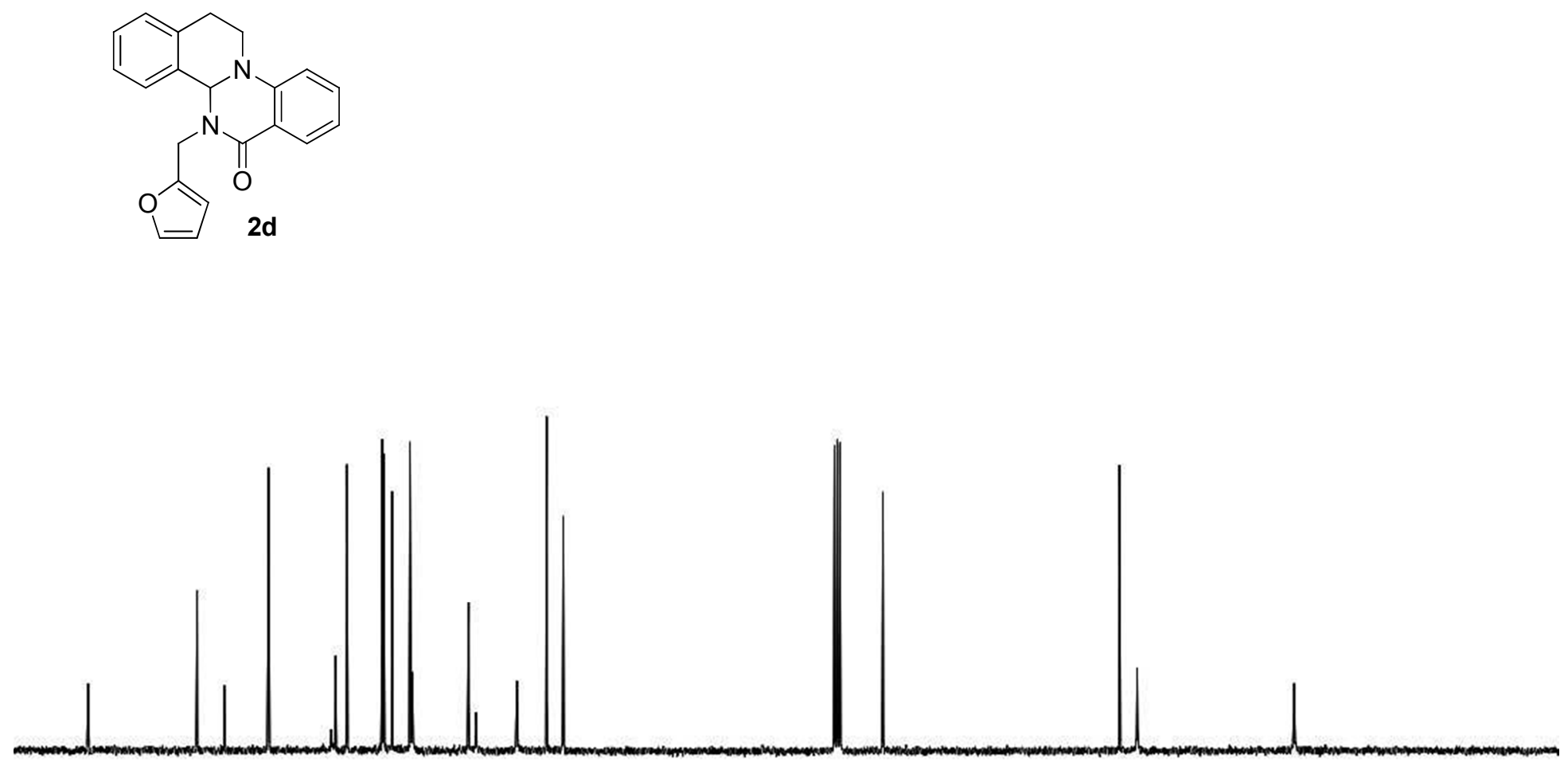


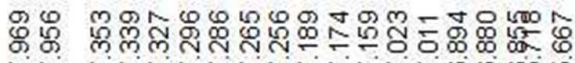

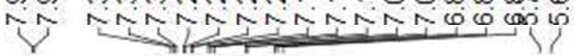

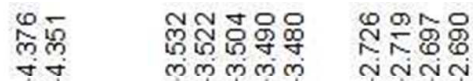
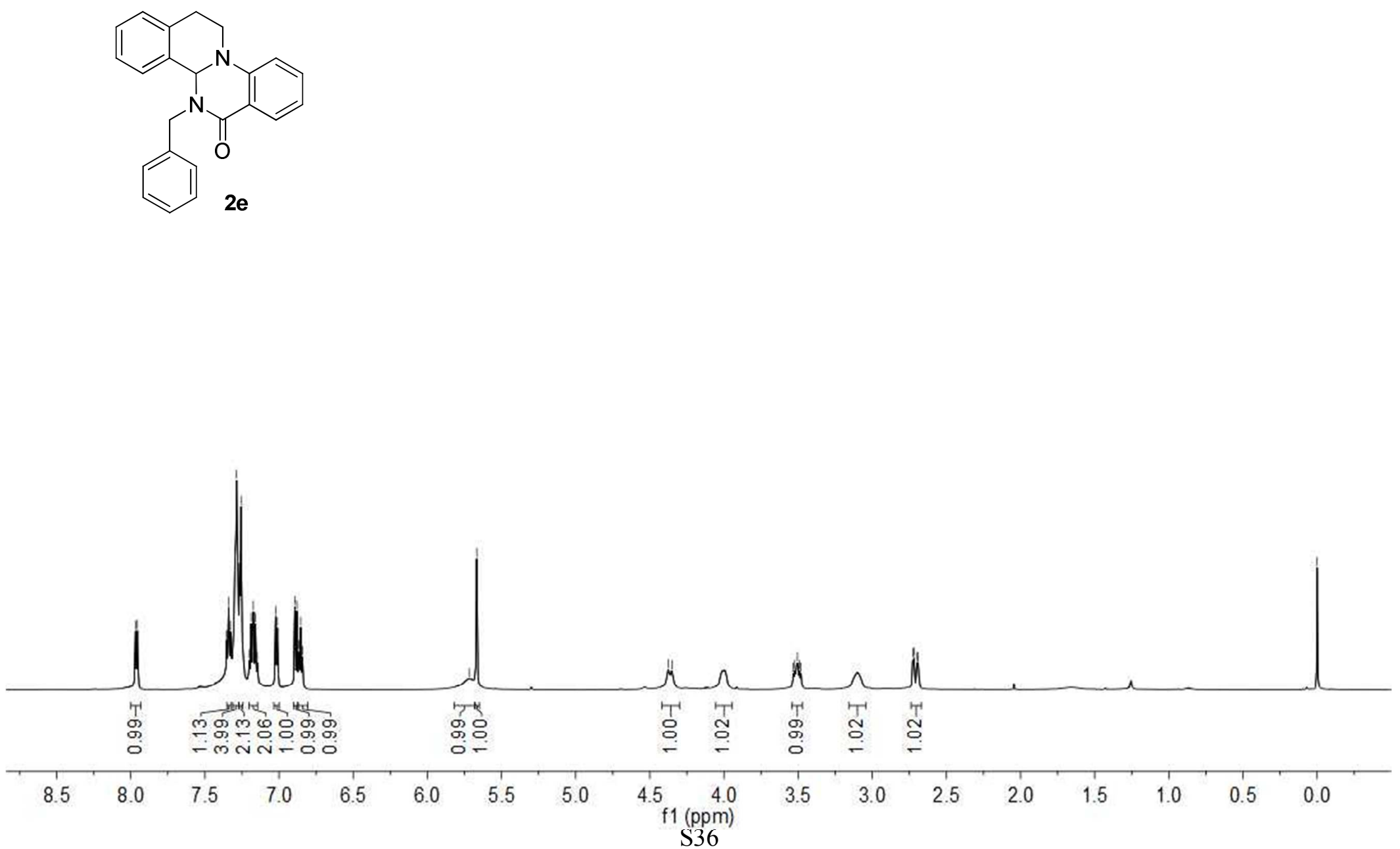

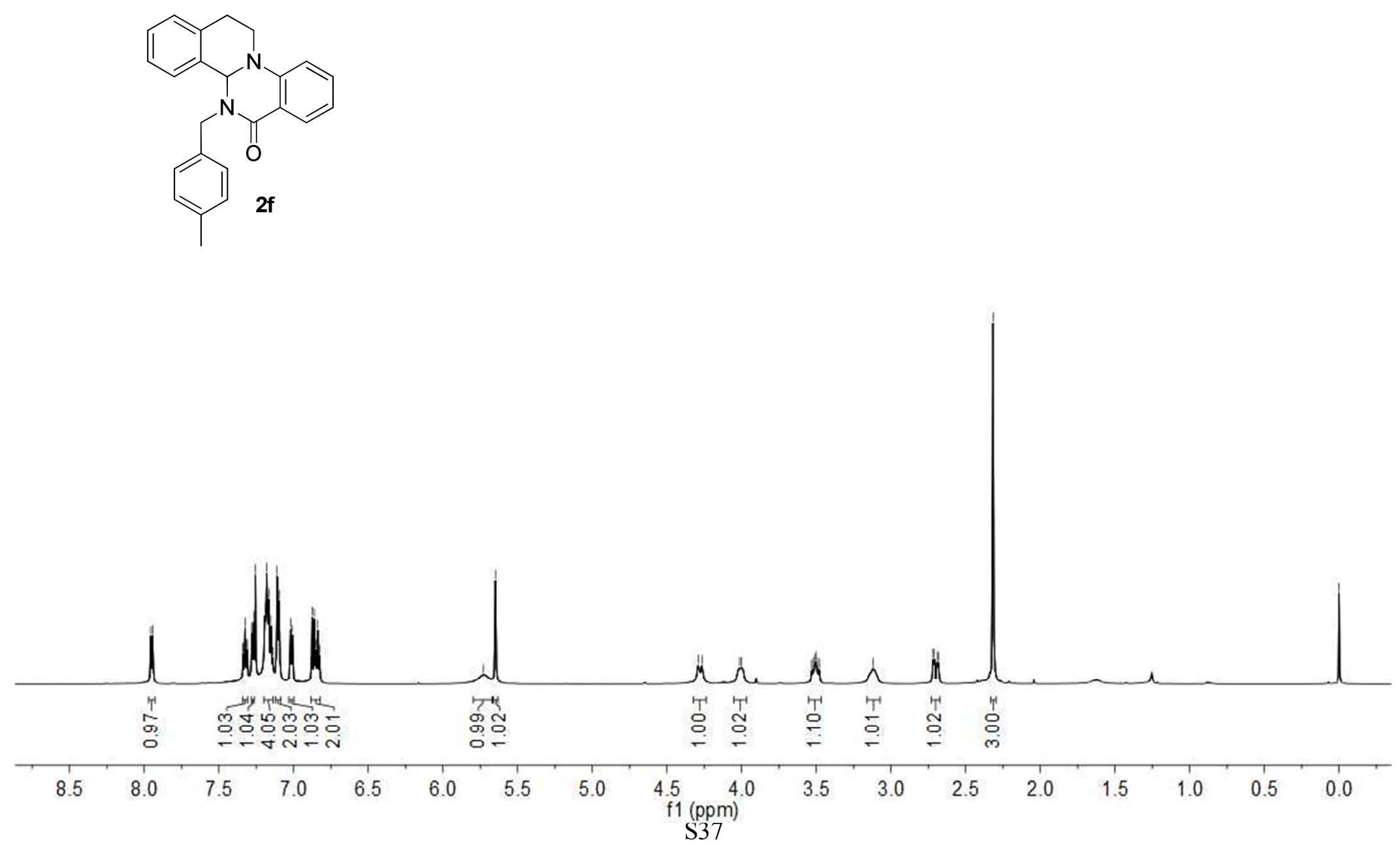


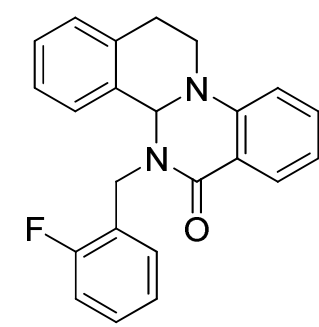

2g

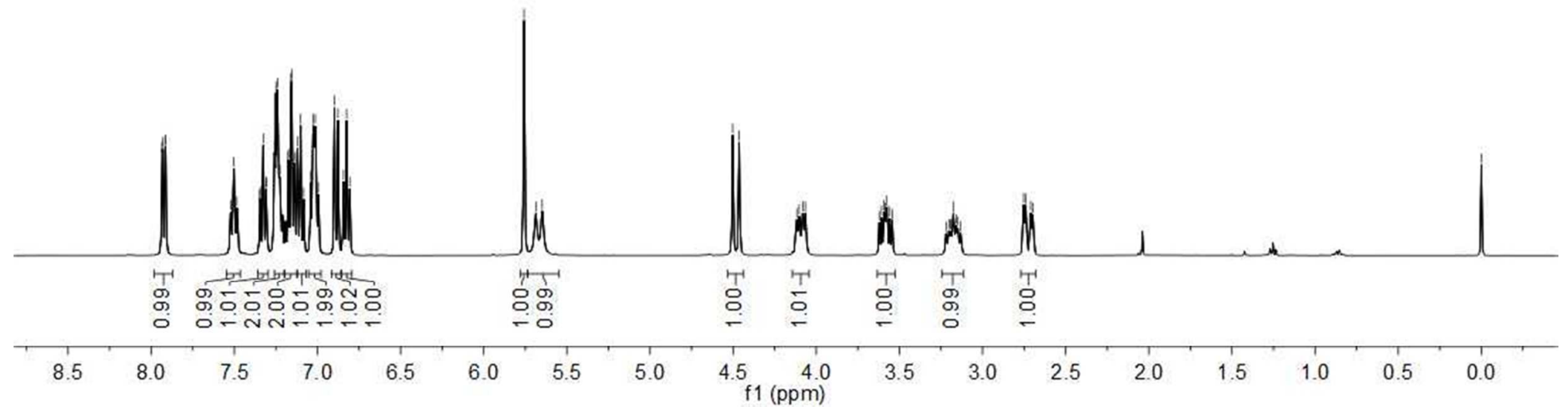




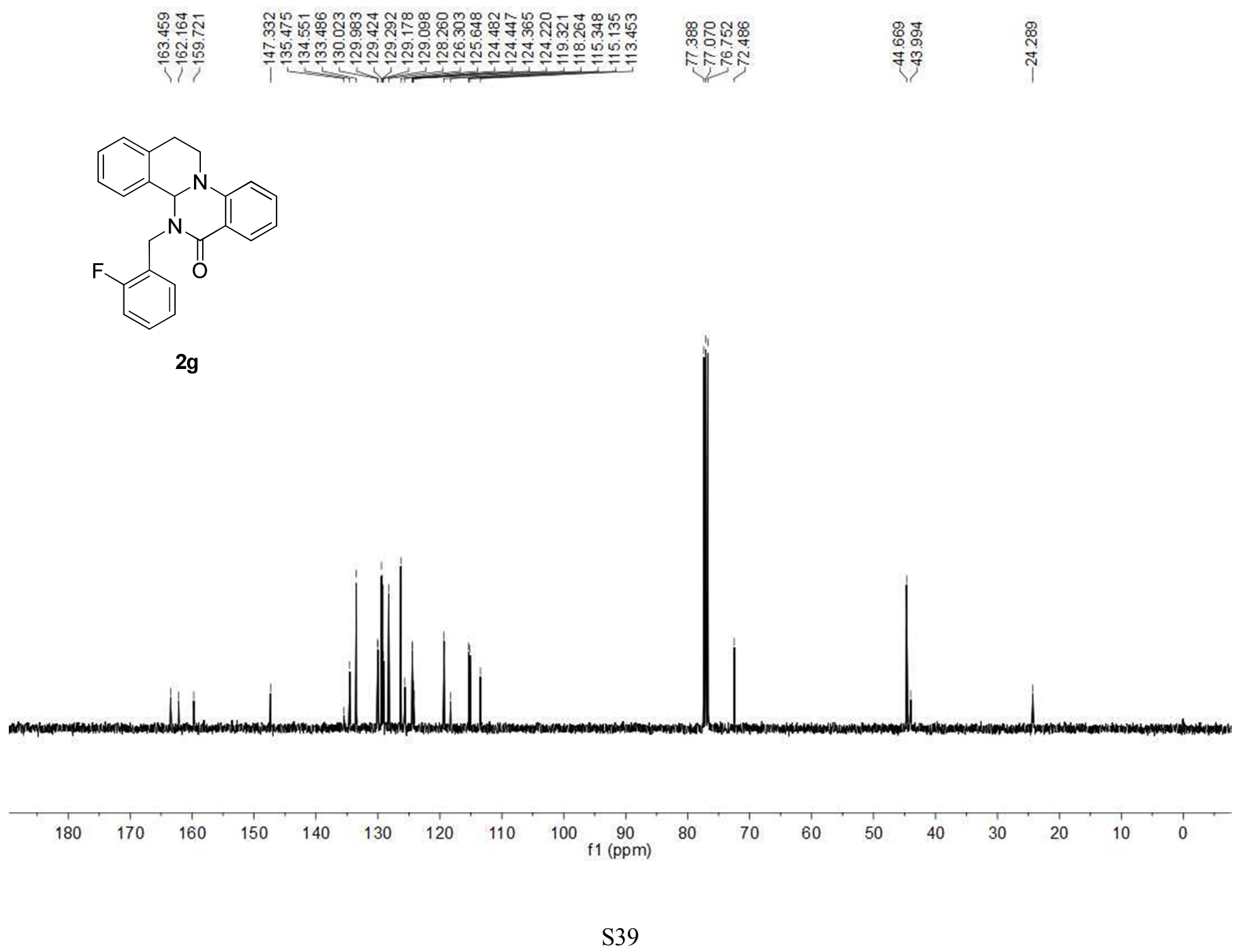



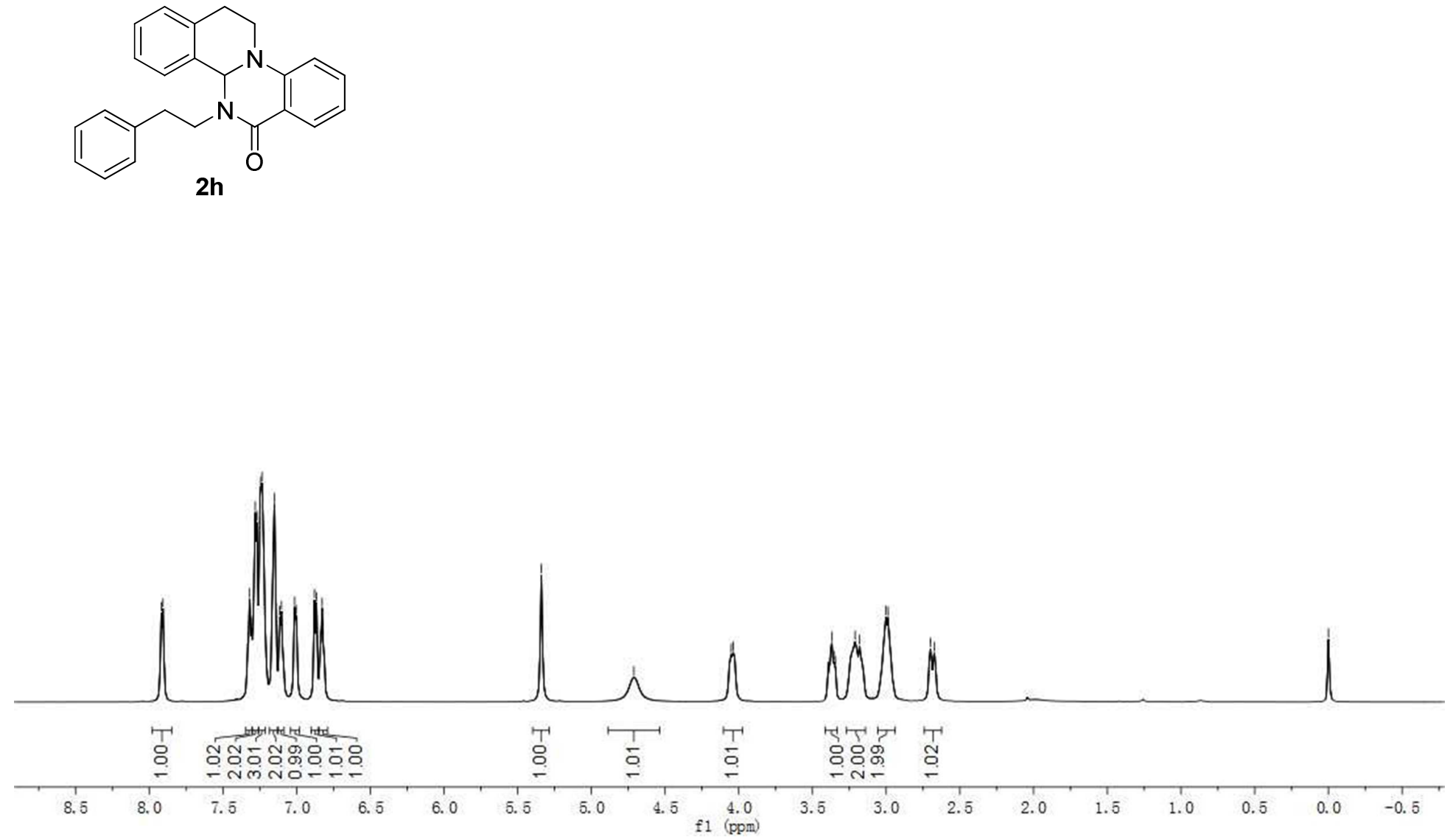


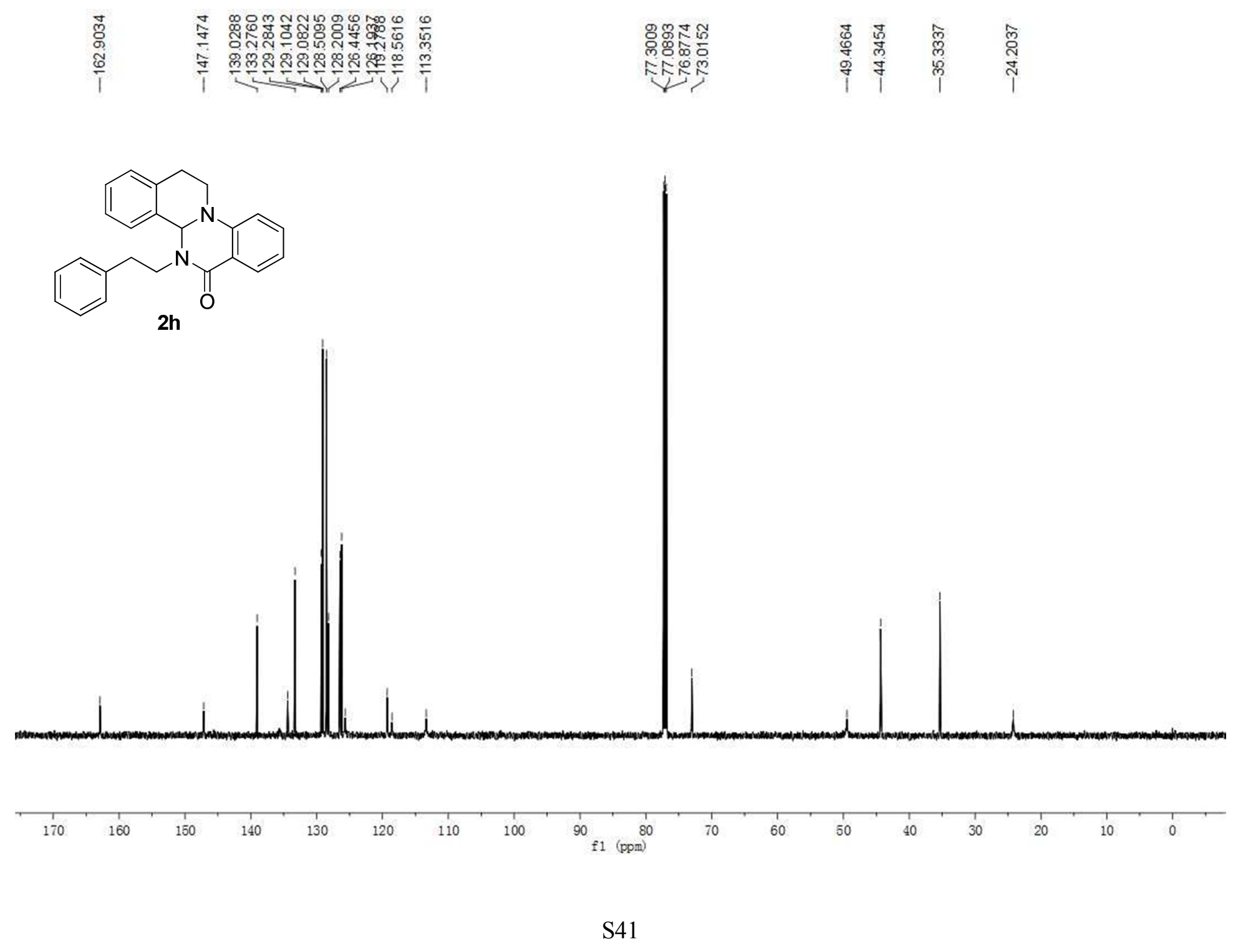




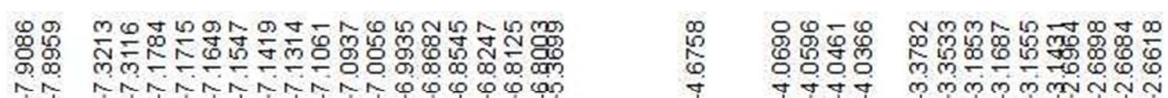

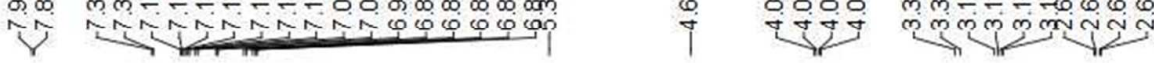
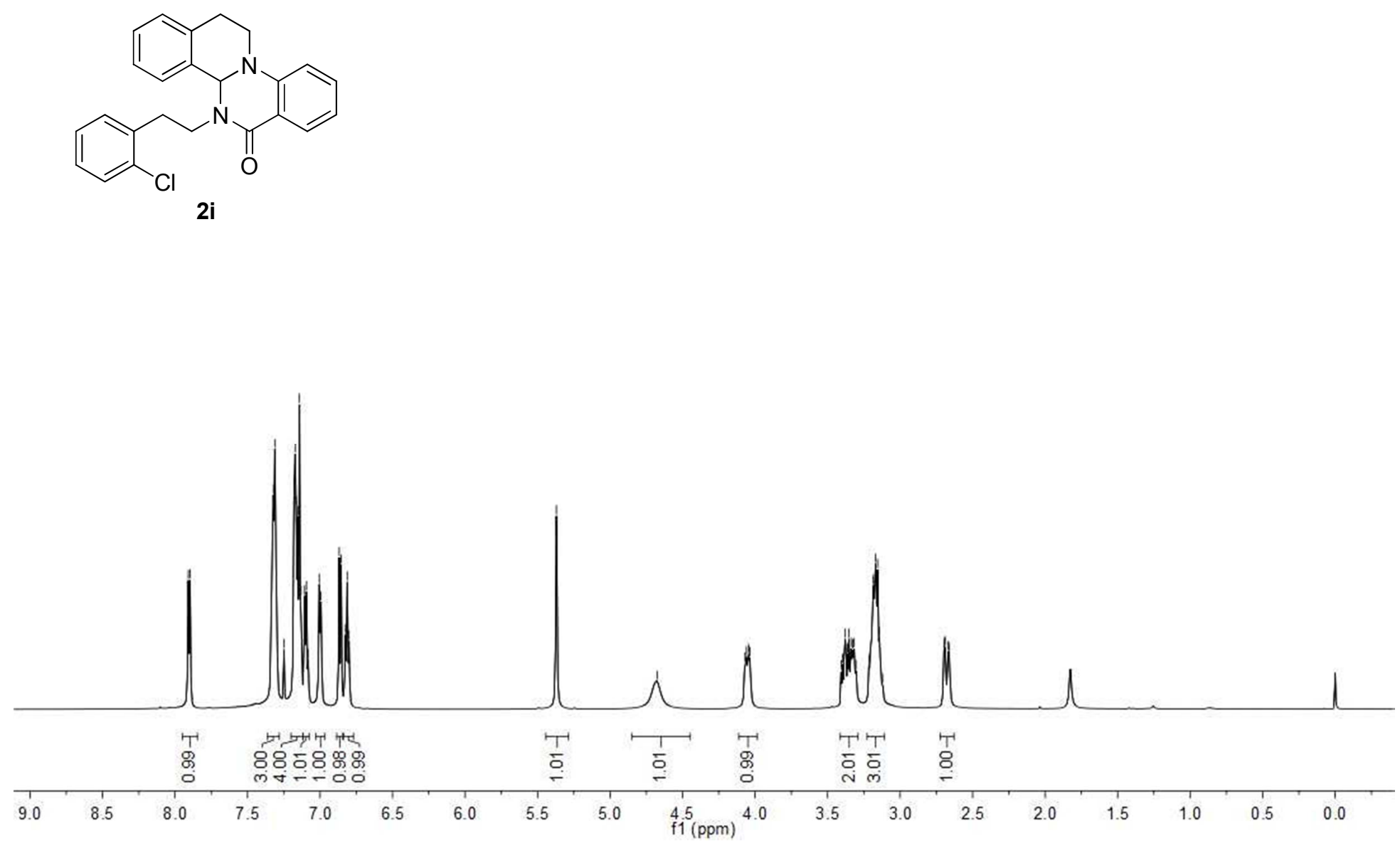


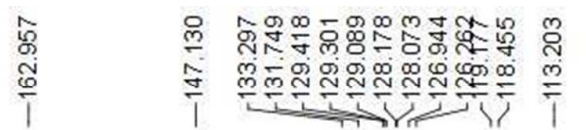

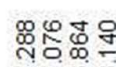

积?

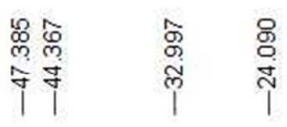

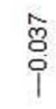
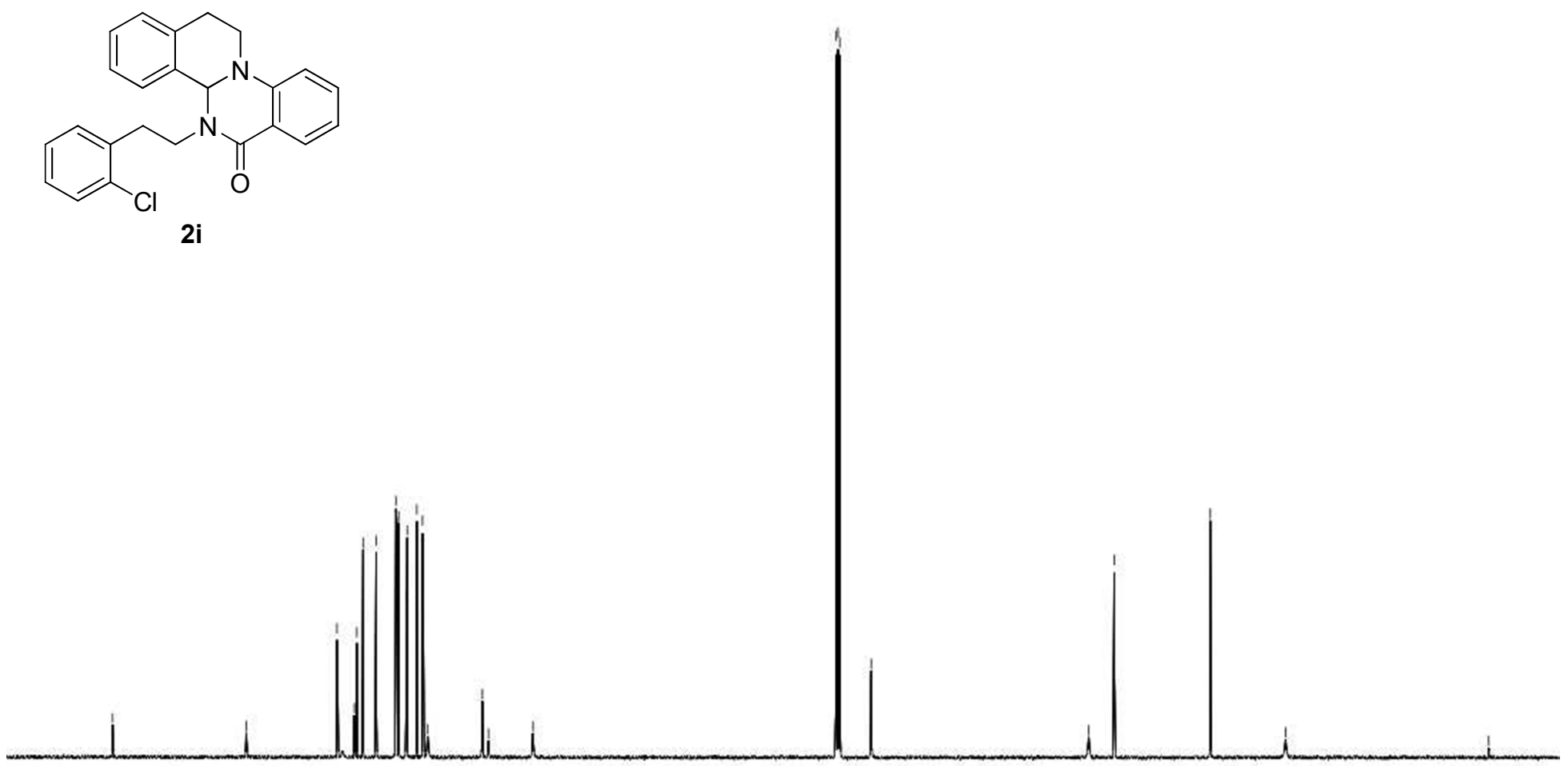

170

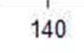

130

120

110

100

$90 \quad 80$ 


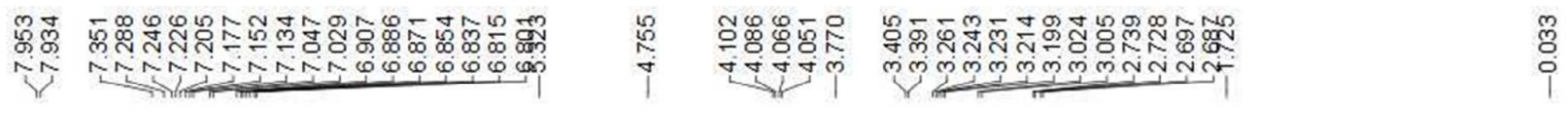
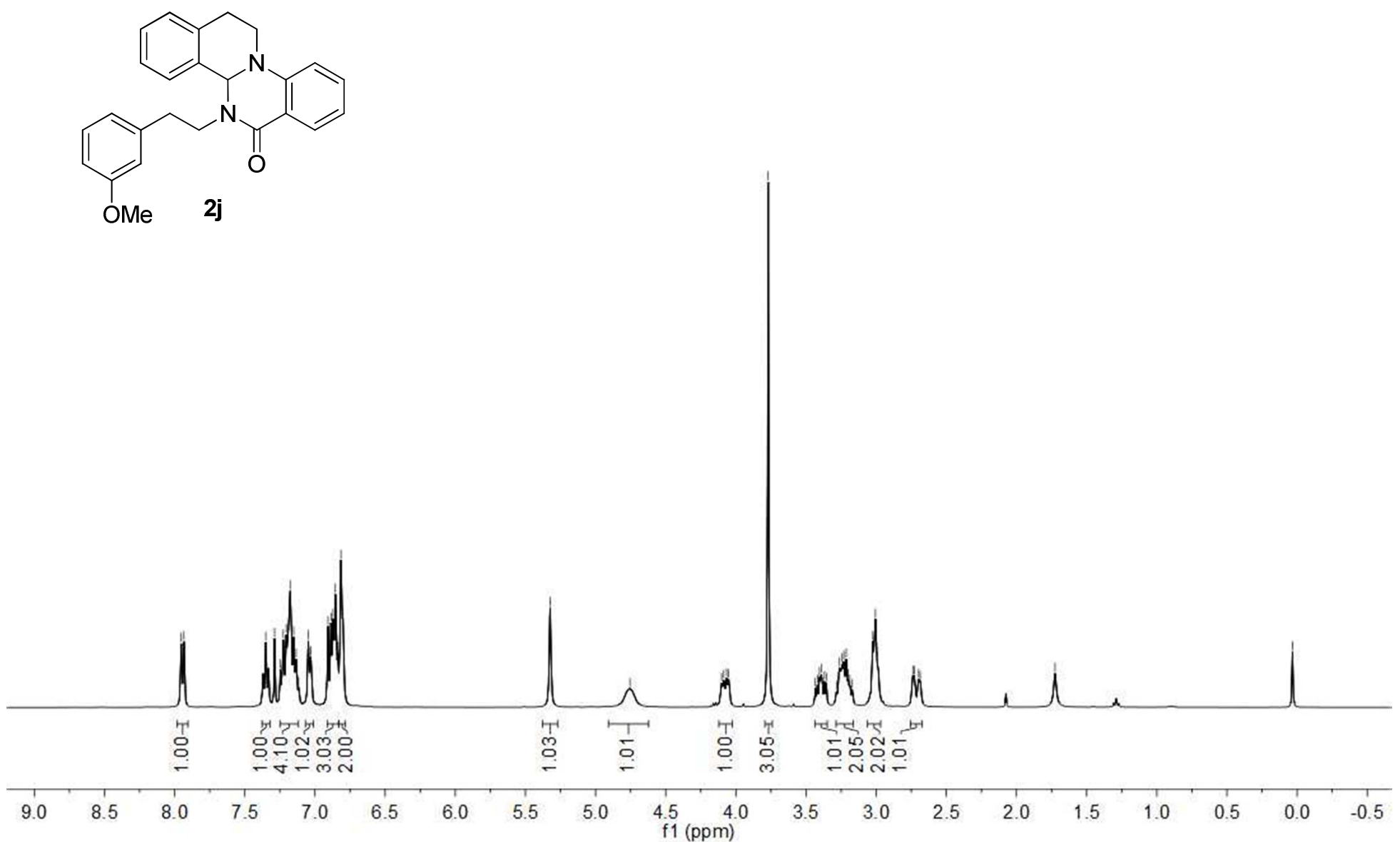

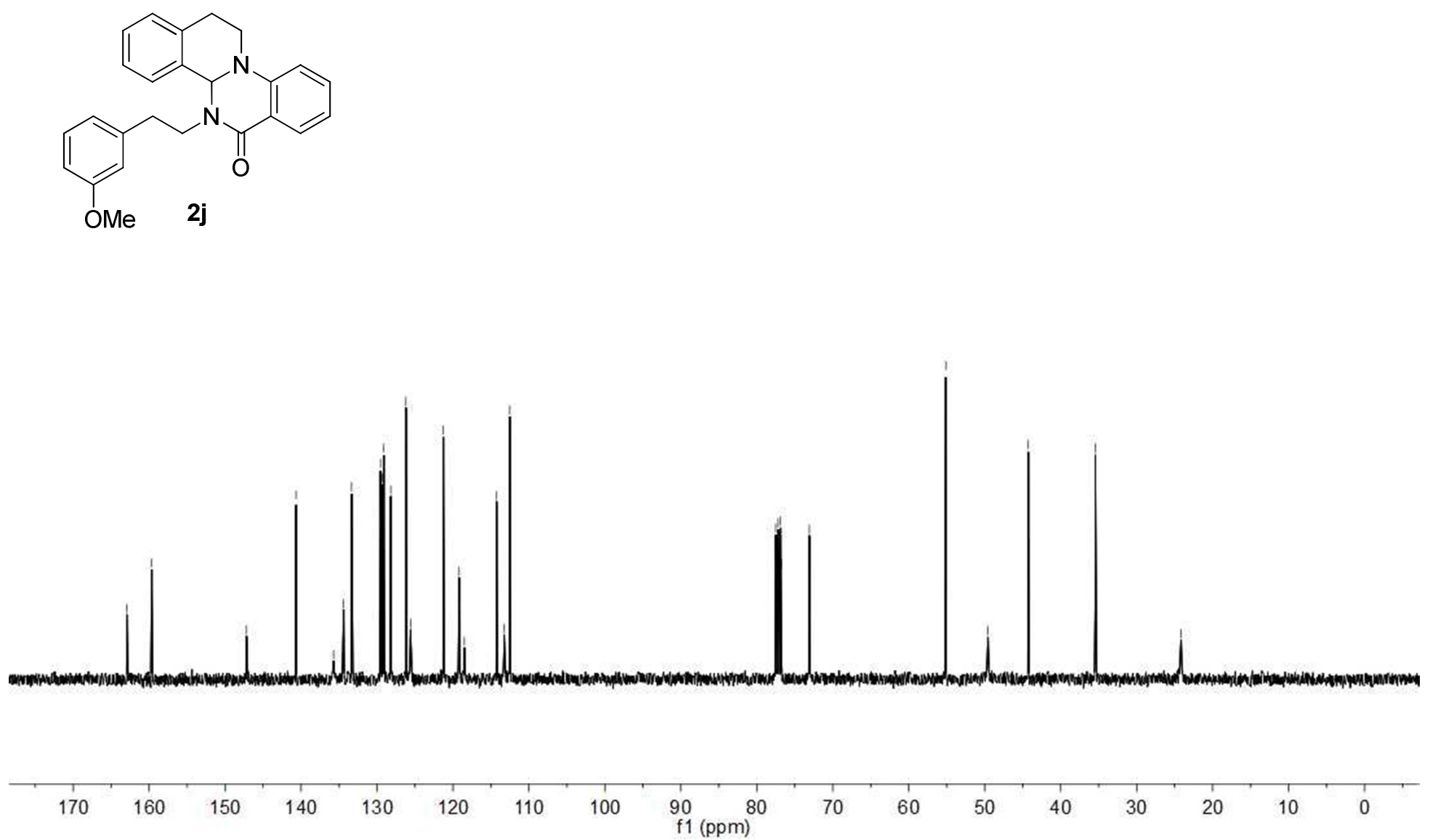


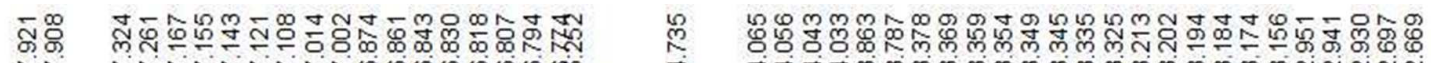

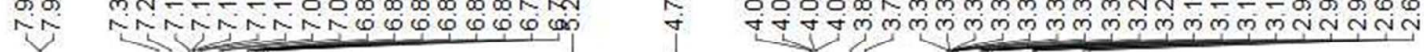
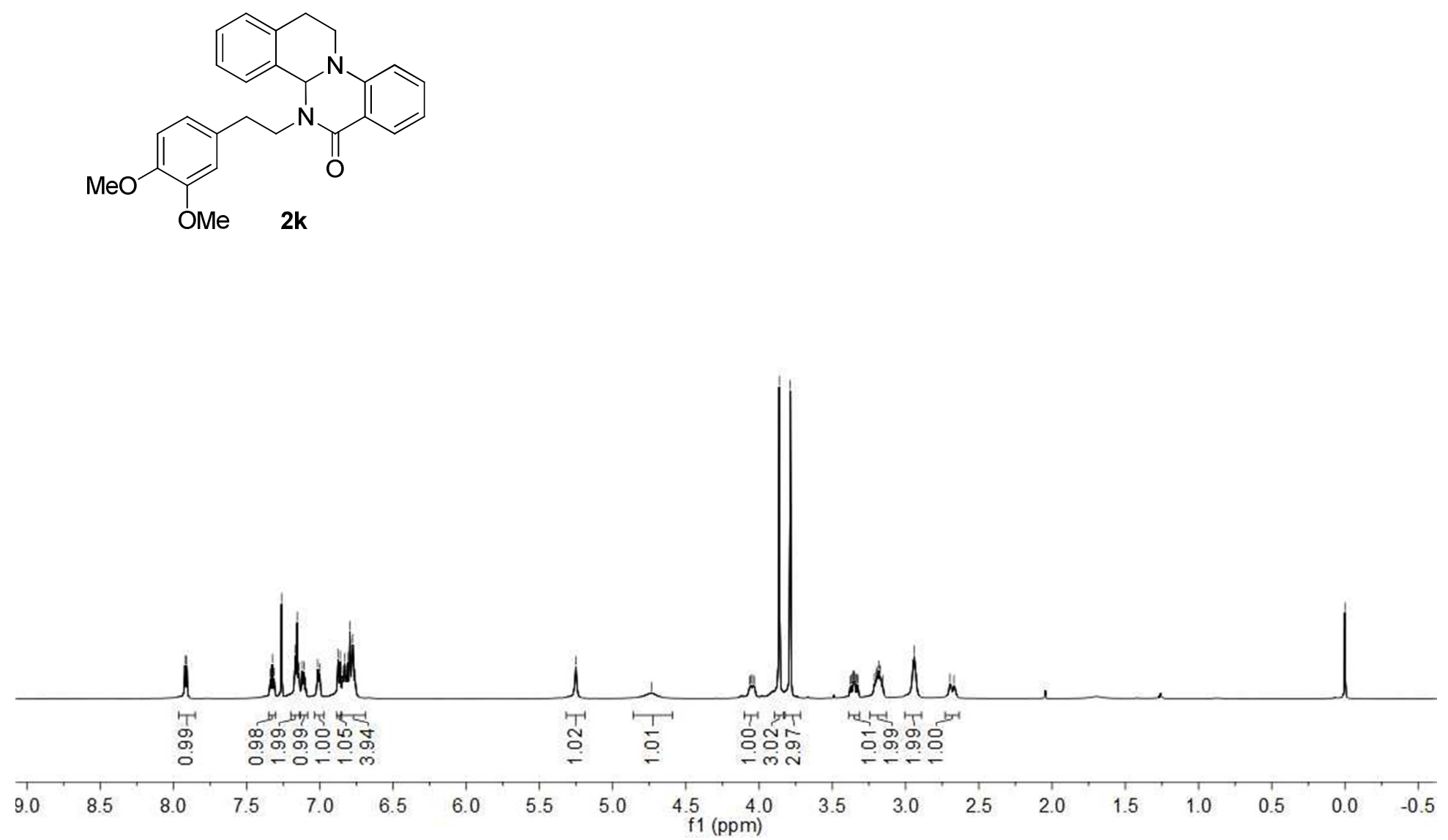


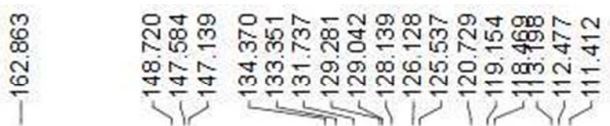

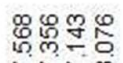

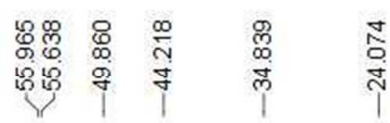
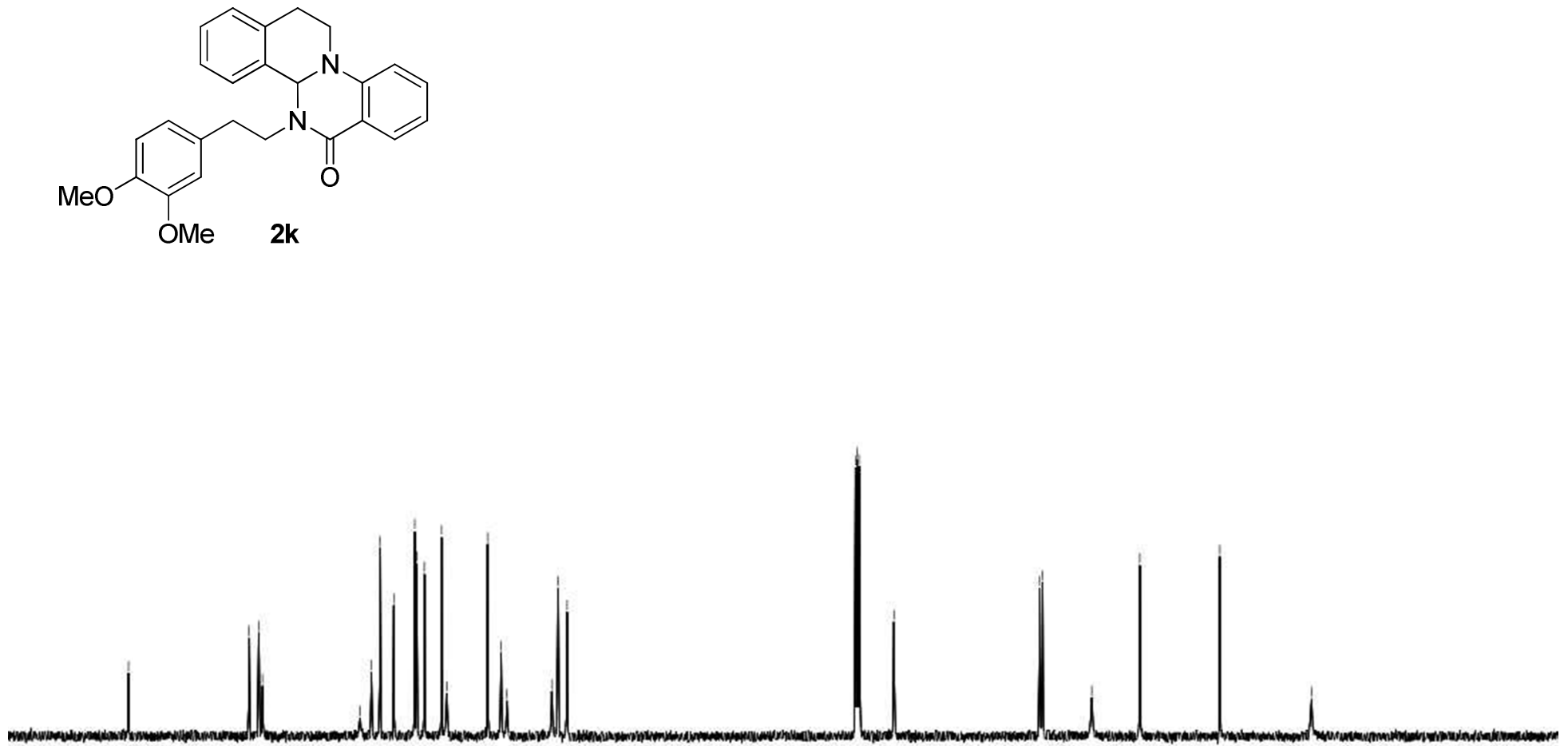


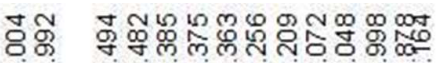

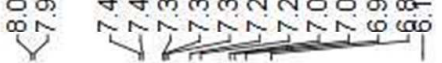

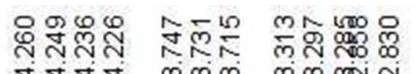

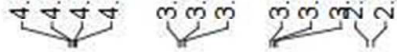
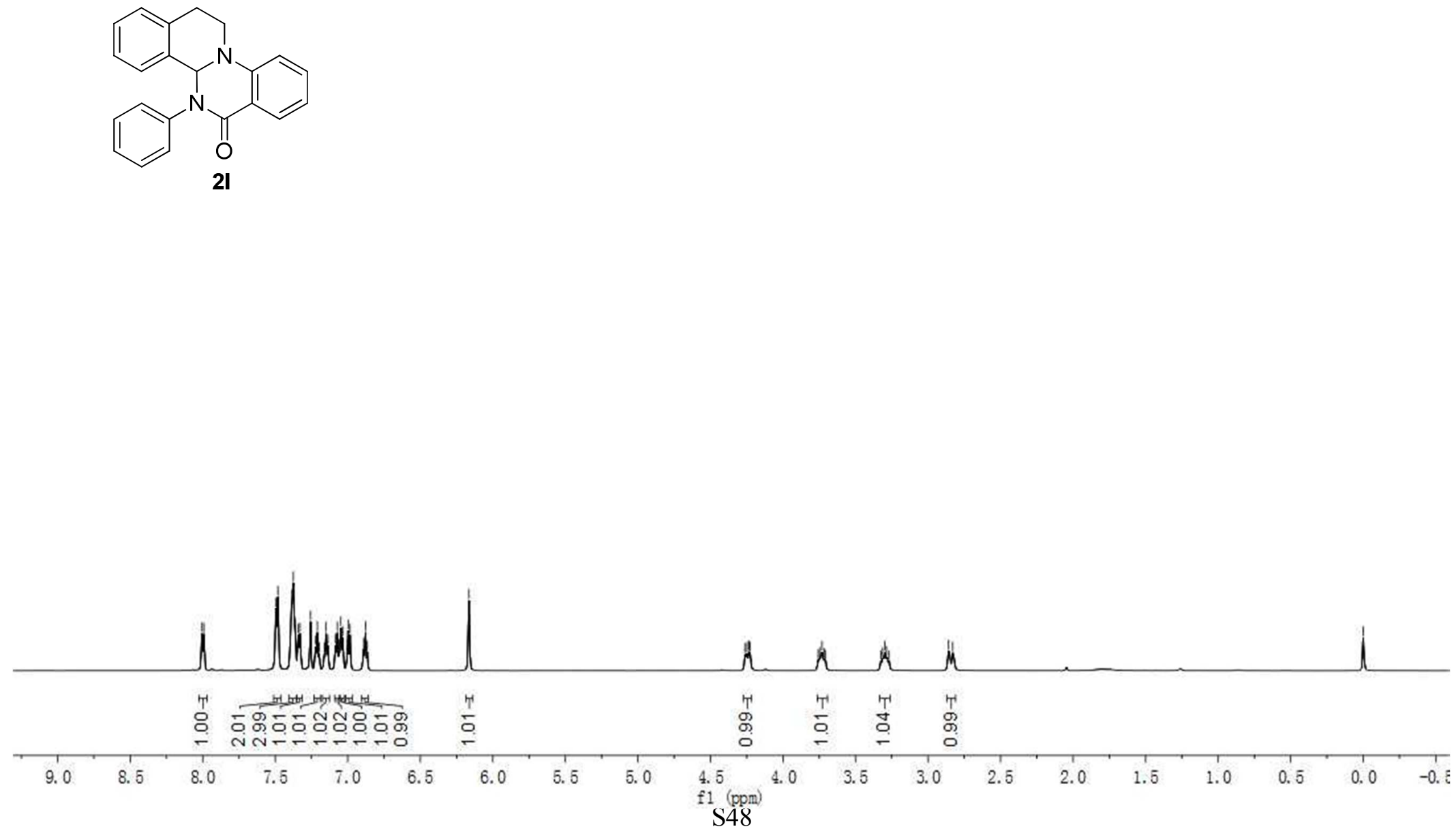


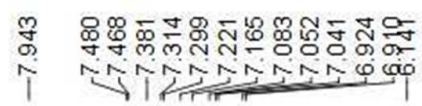

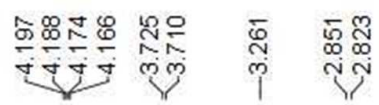
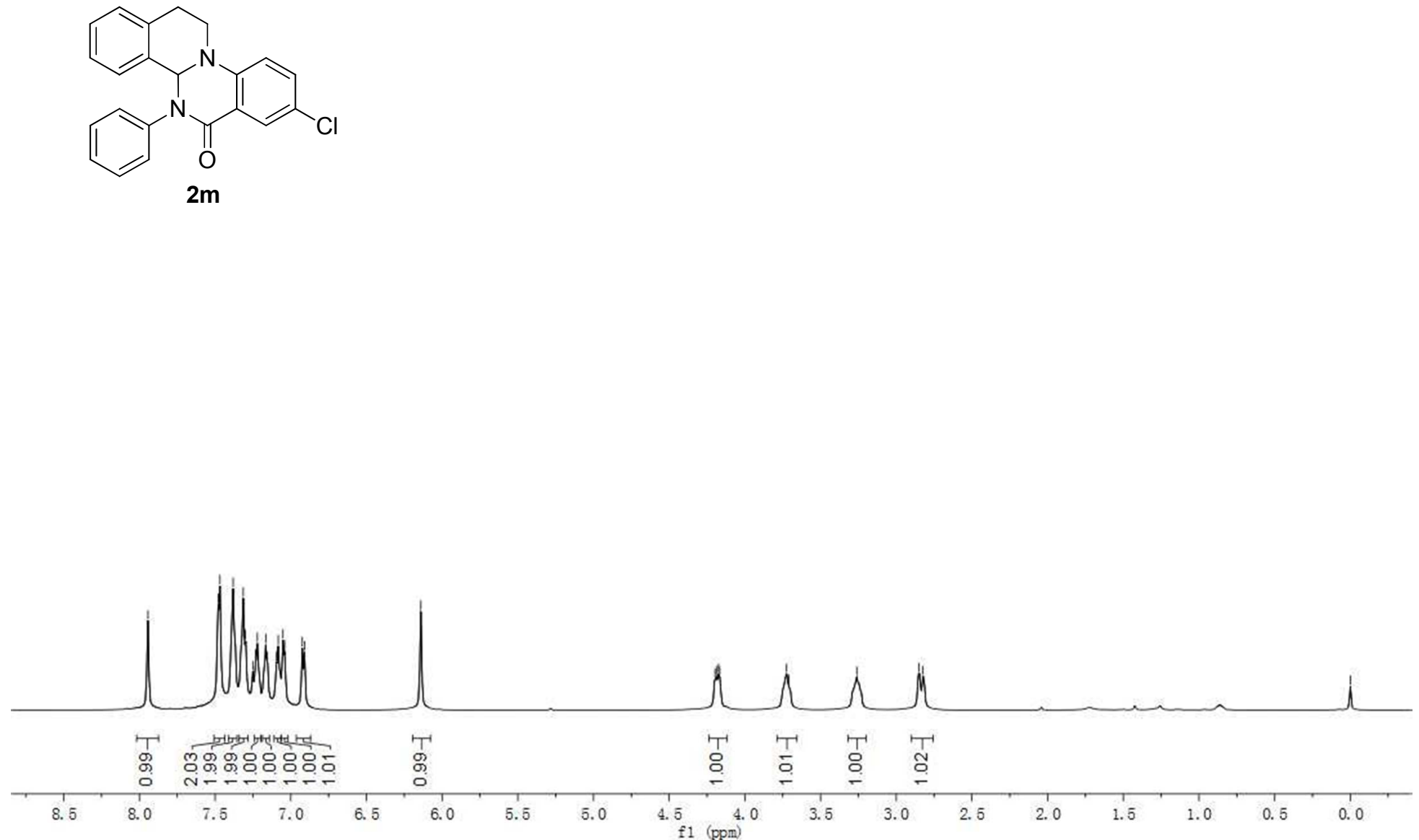

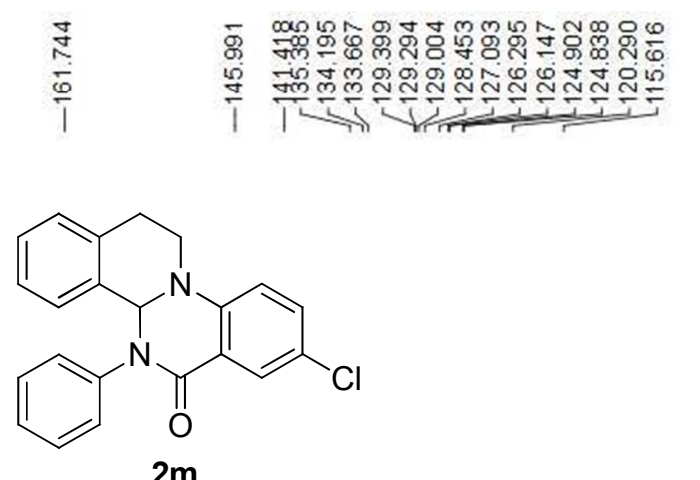

$2 \mathrm{~m}$

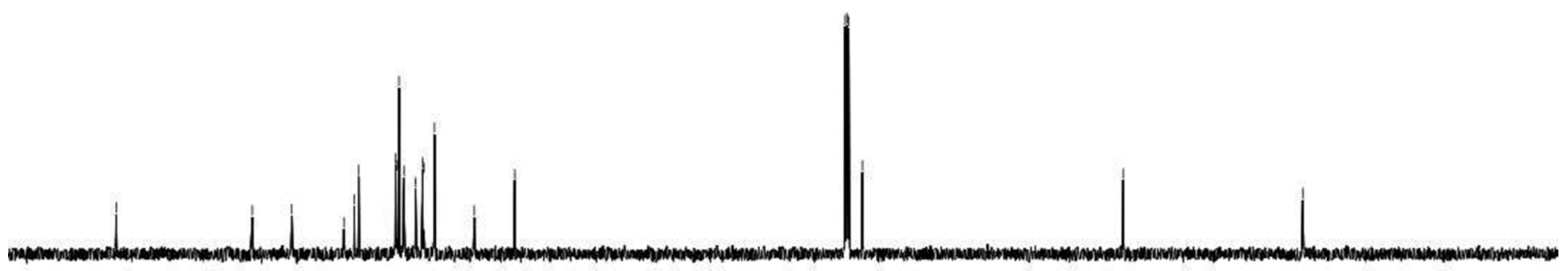




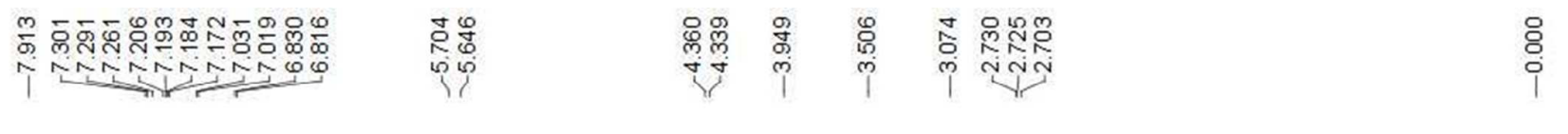
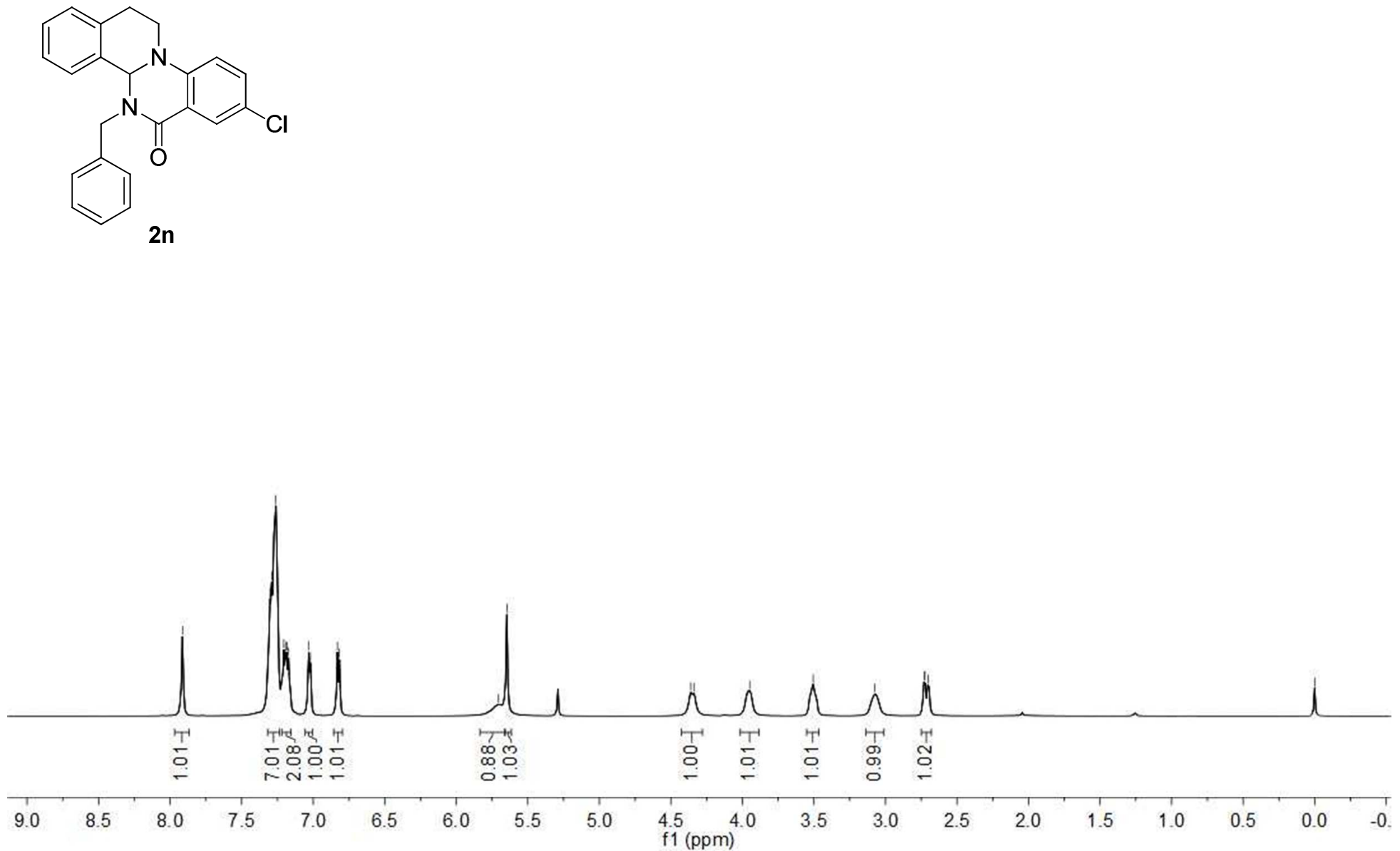


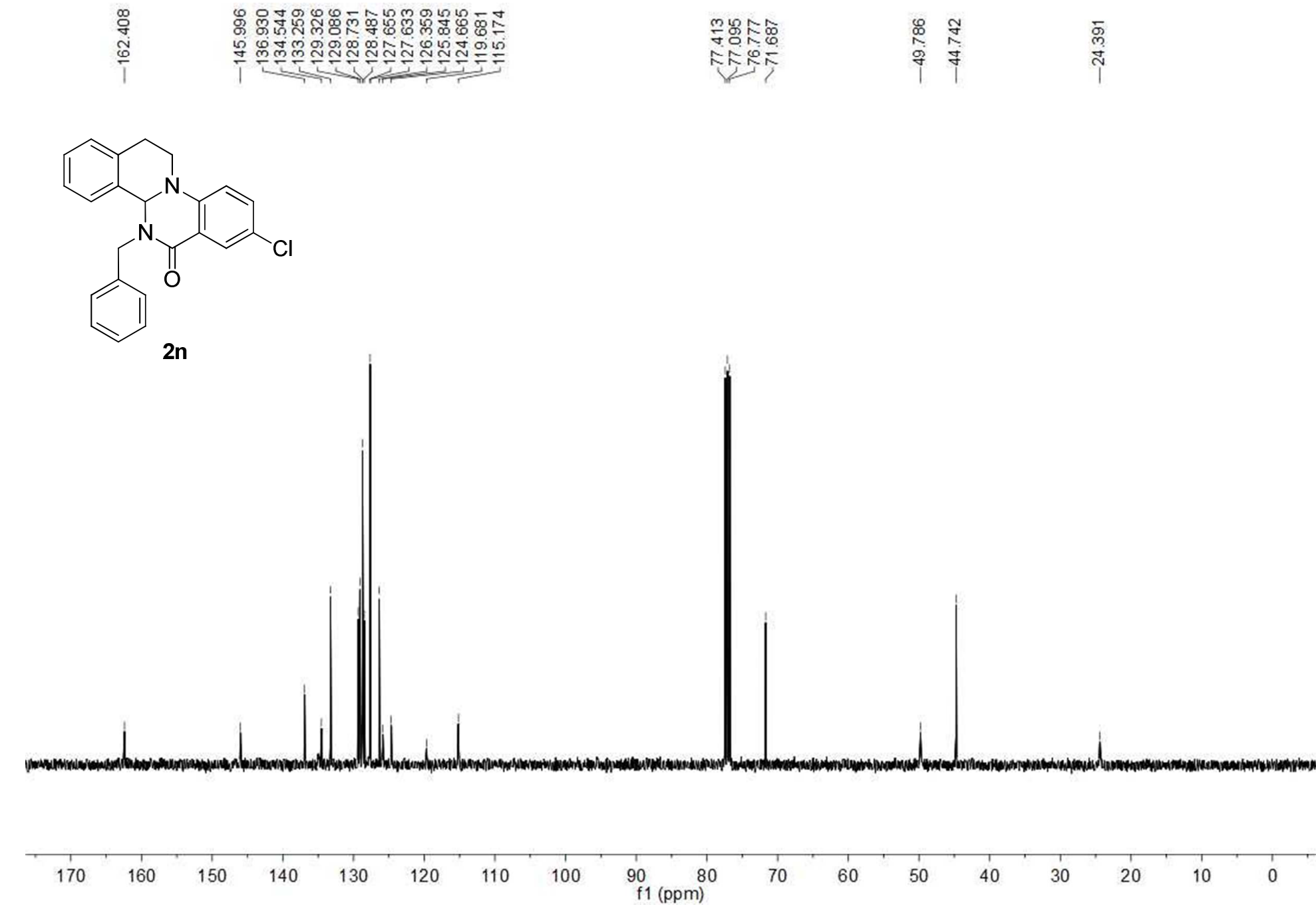




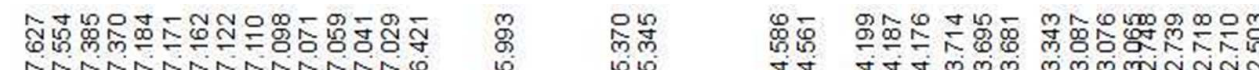

rinininininis
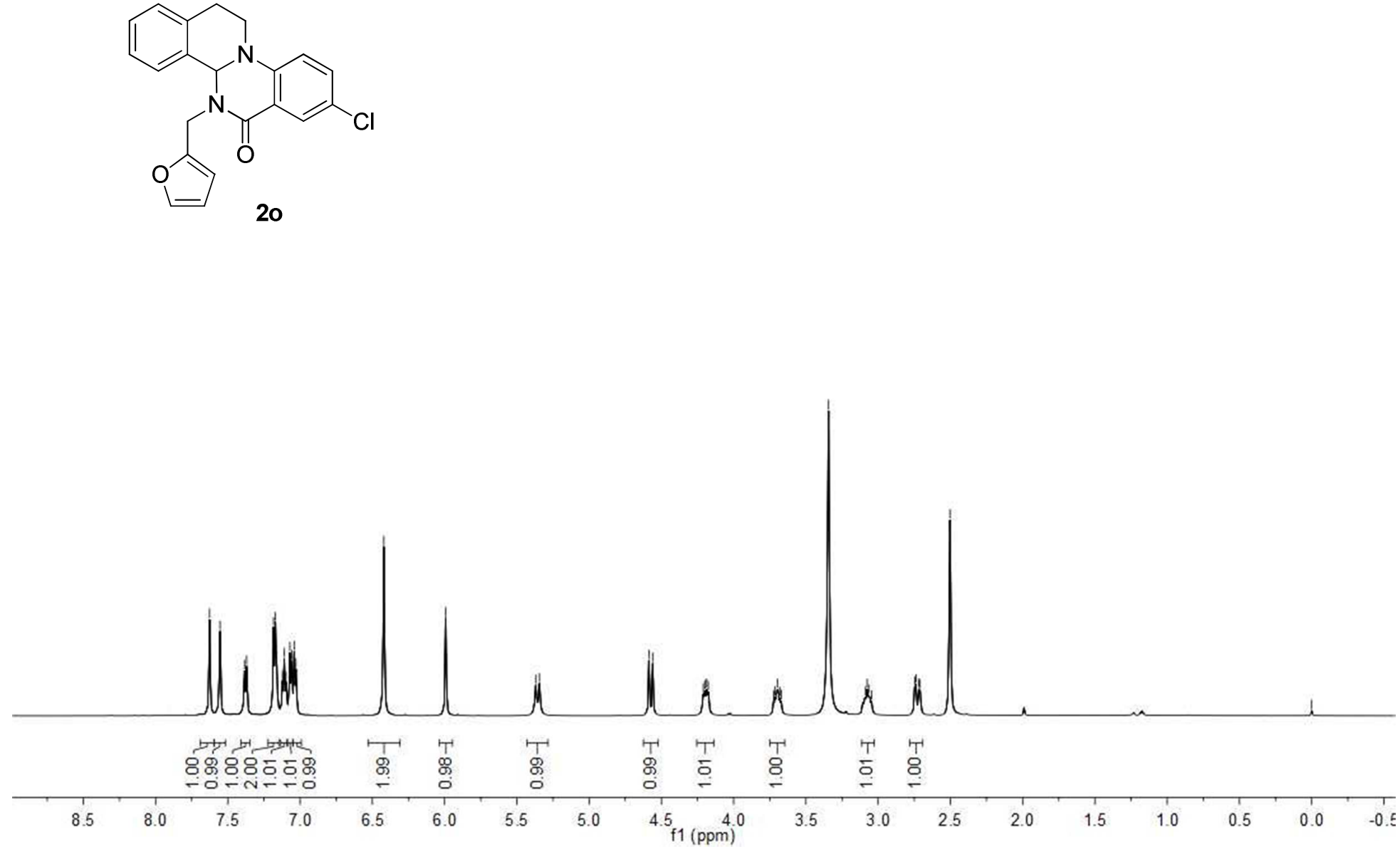


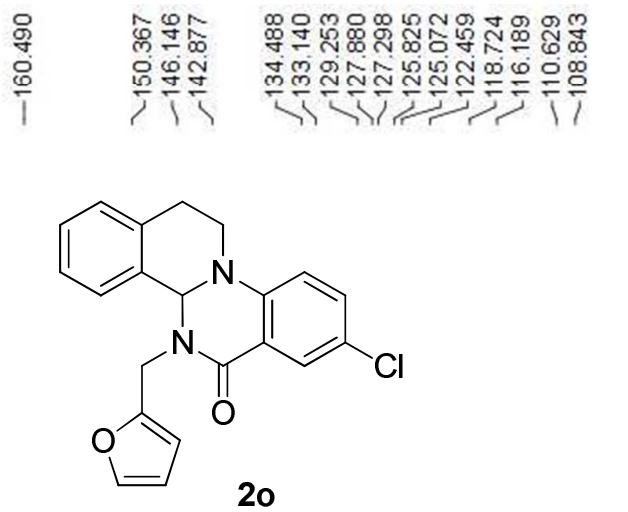

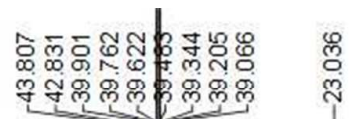

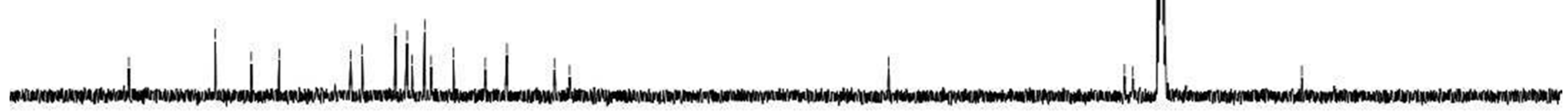

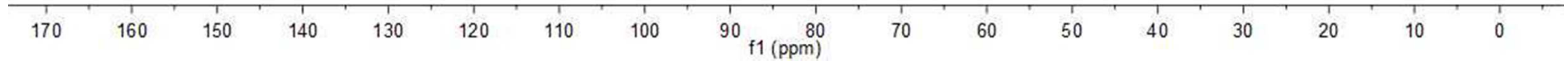




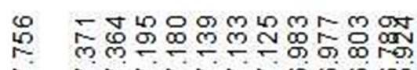

i vintrivesecis

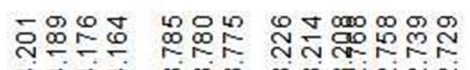

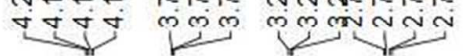

$\underset{\square}{\stackrel{8}{\circ}}$

옹

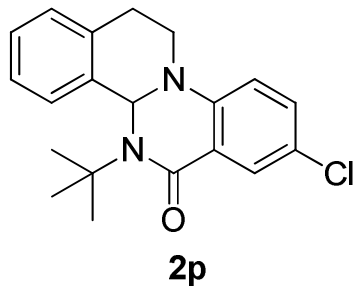

$2 p$

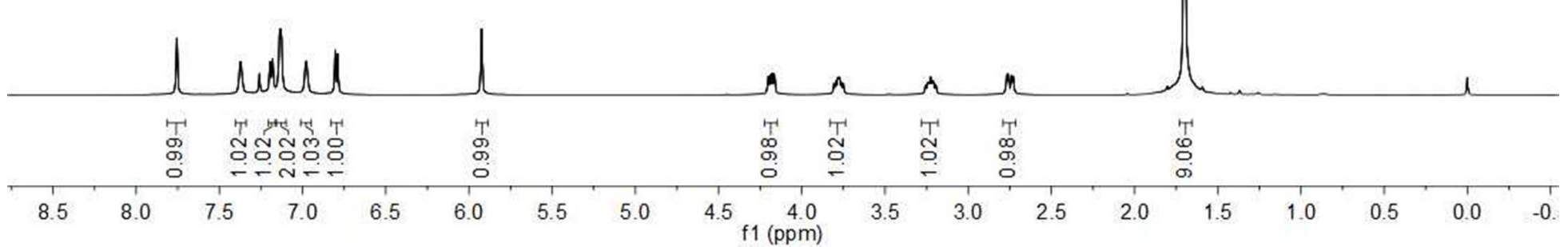




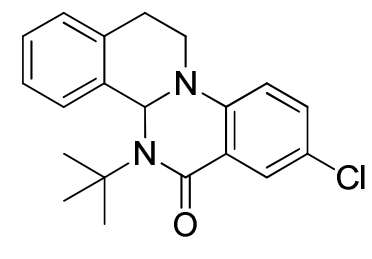

$2 p$

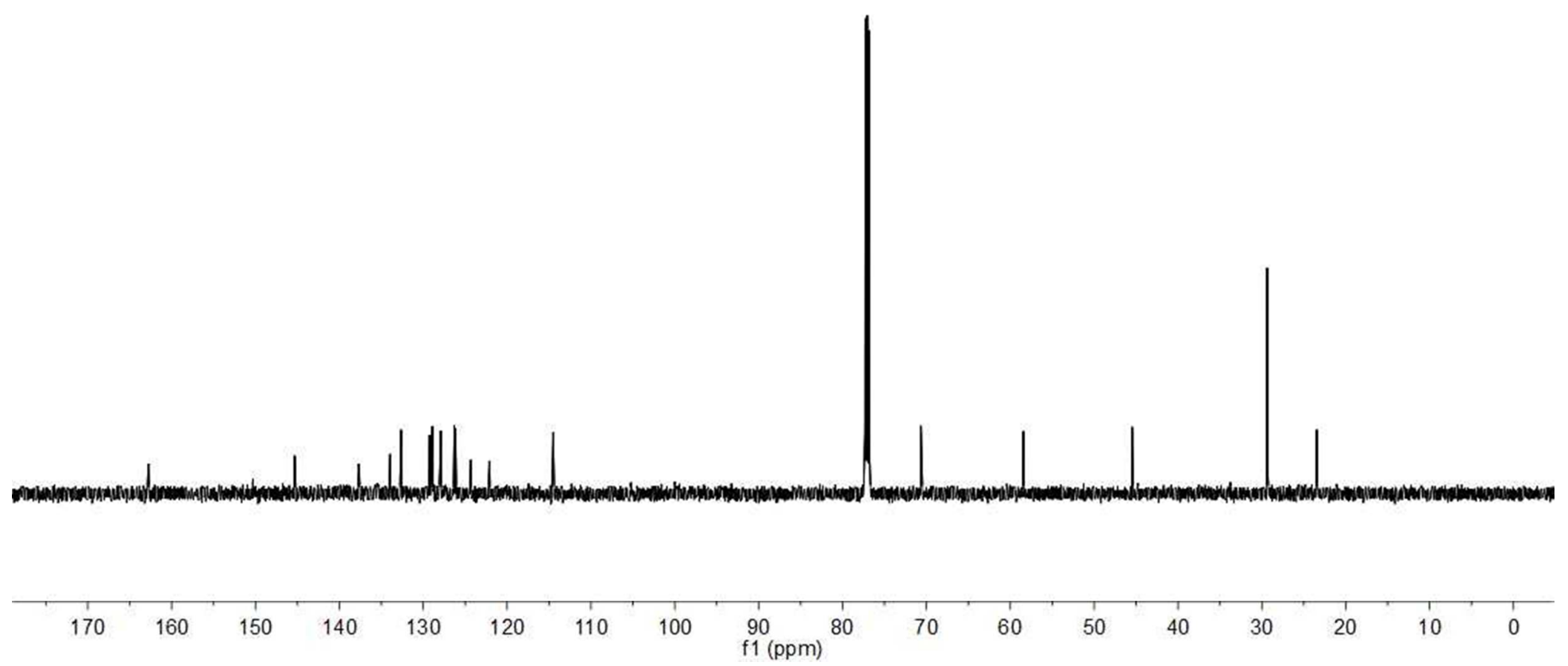




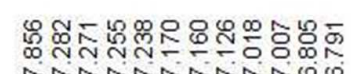

T包

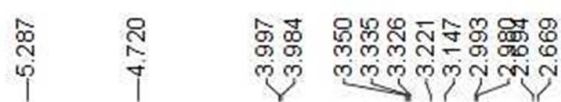

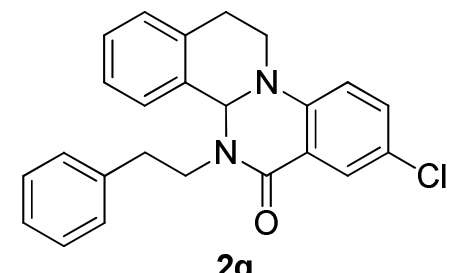

$2 q$

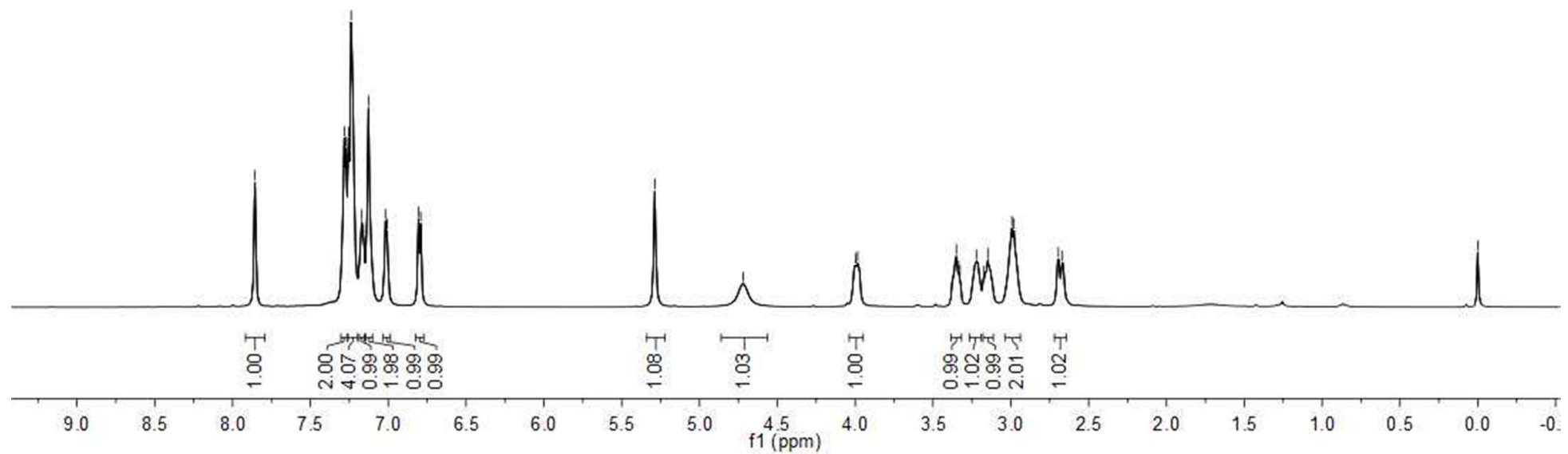




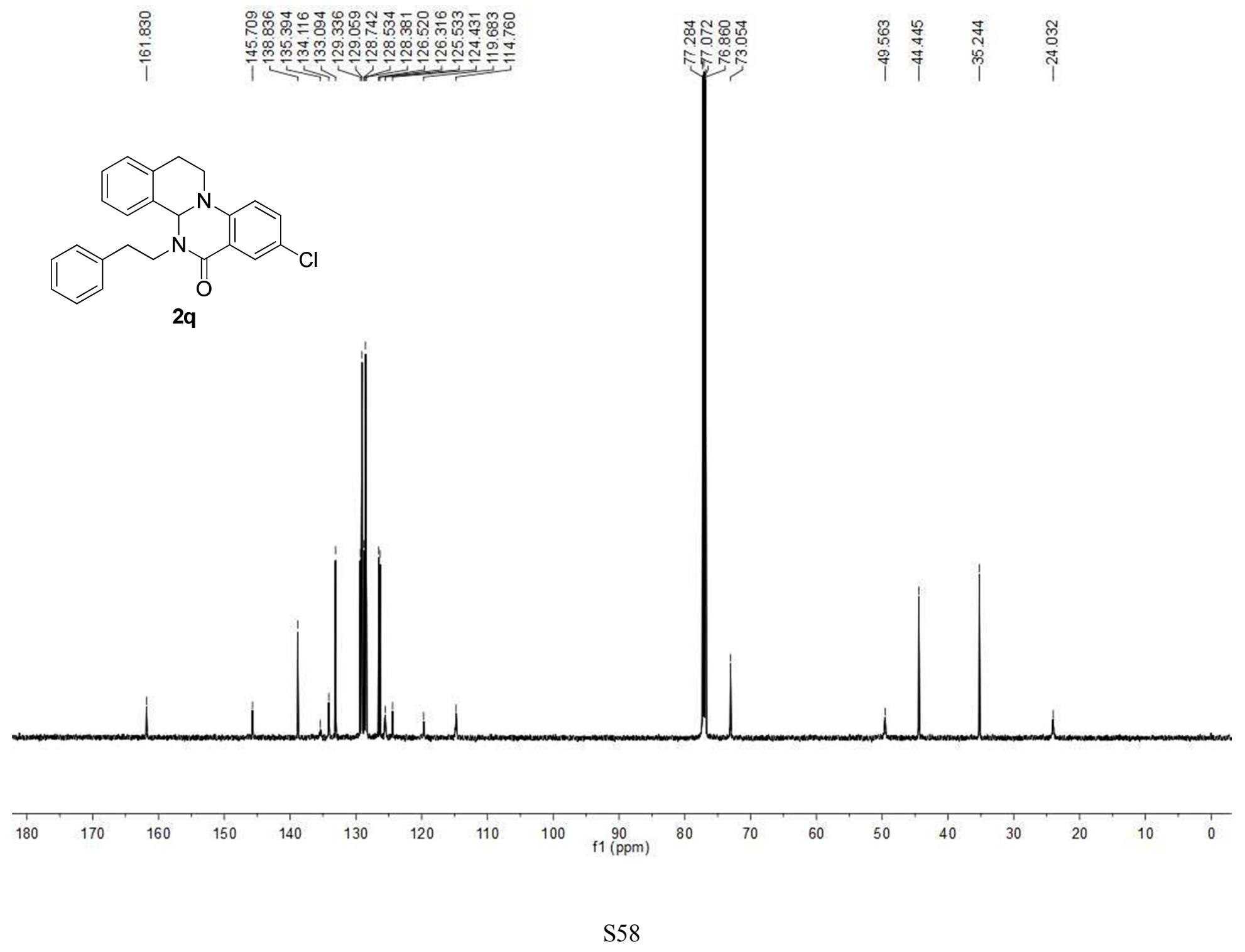



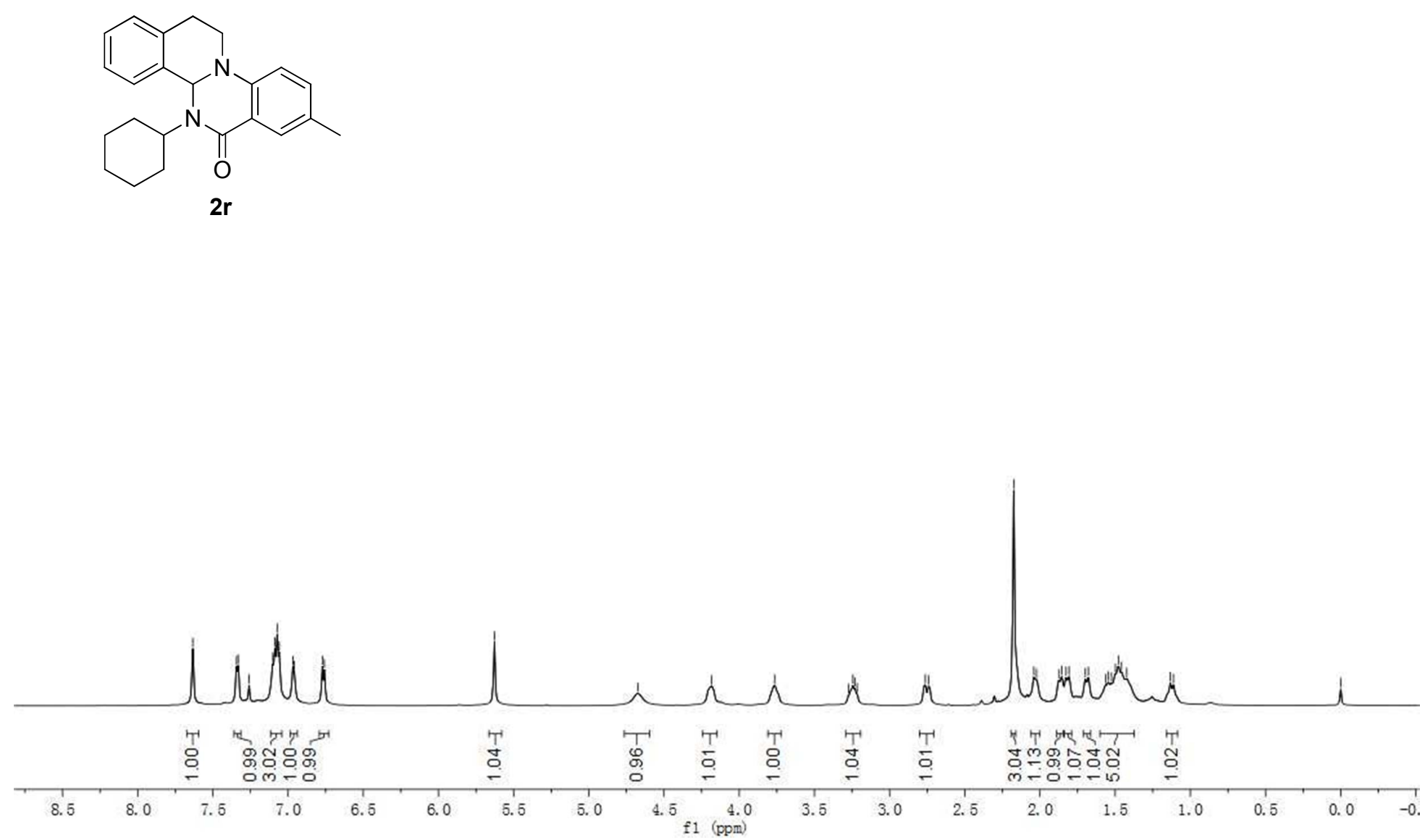

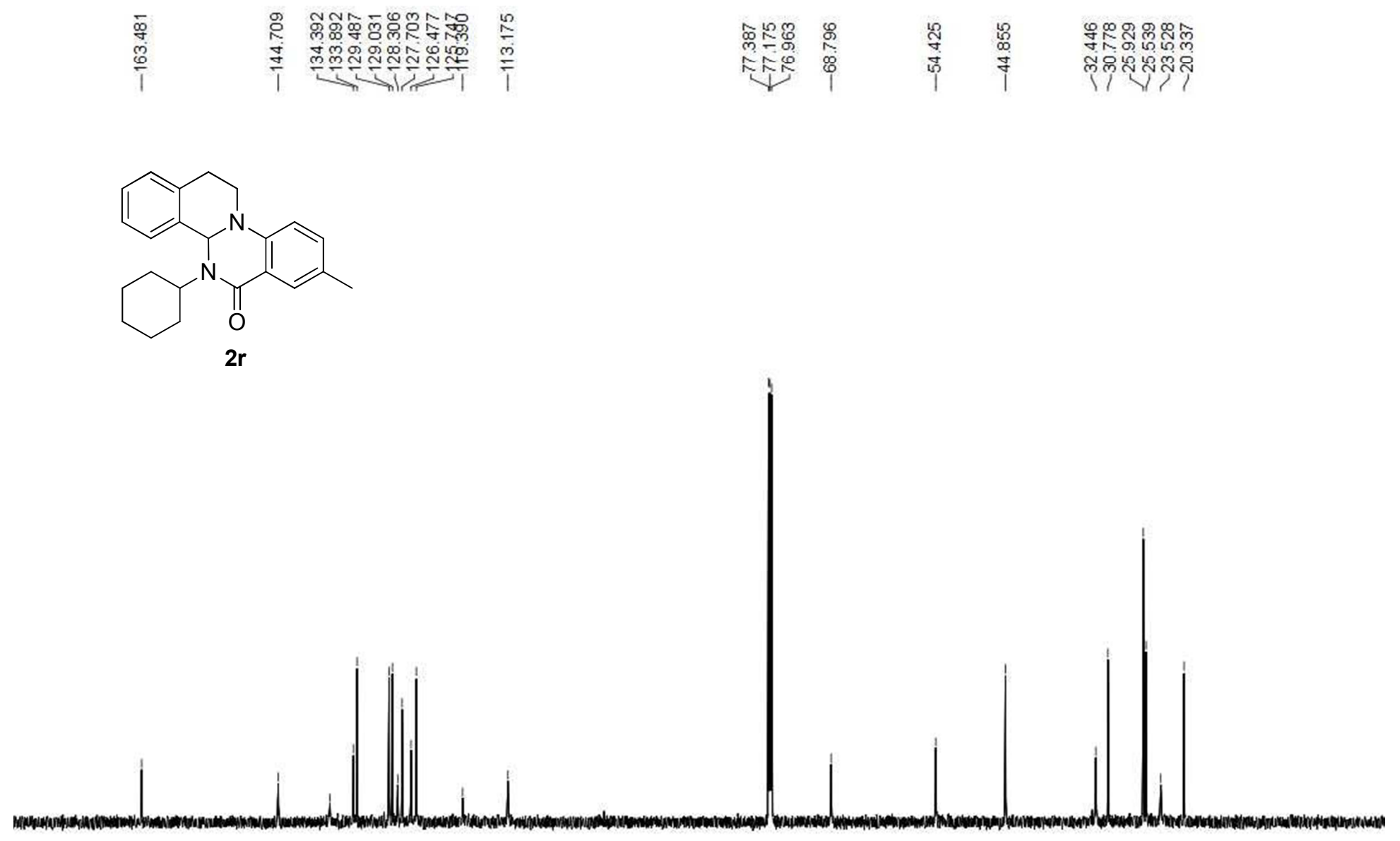


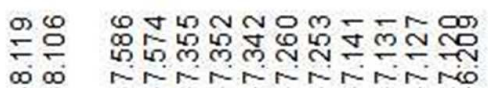

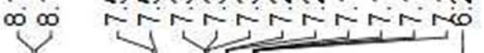

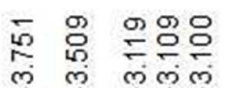

iा गुल
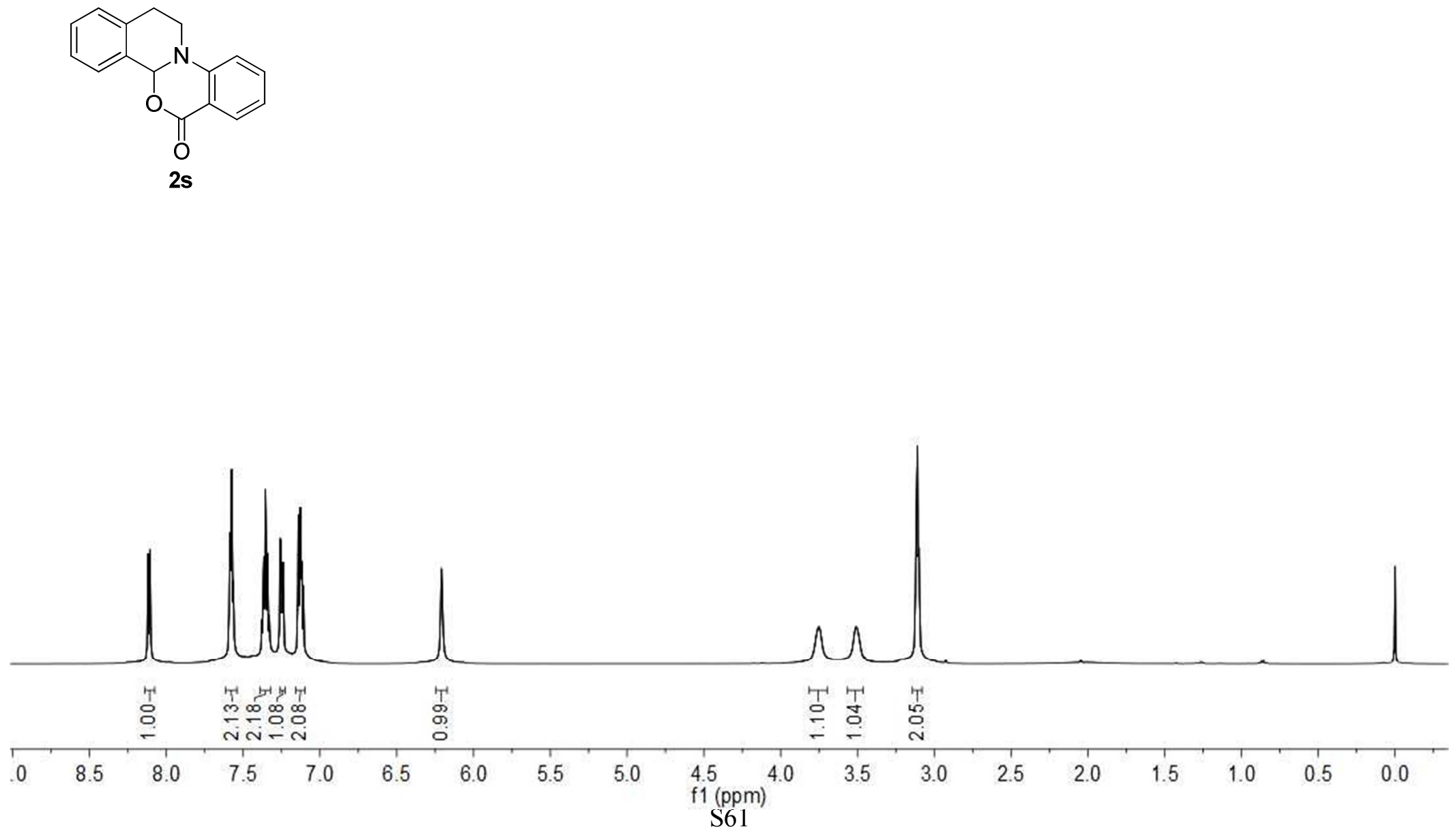


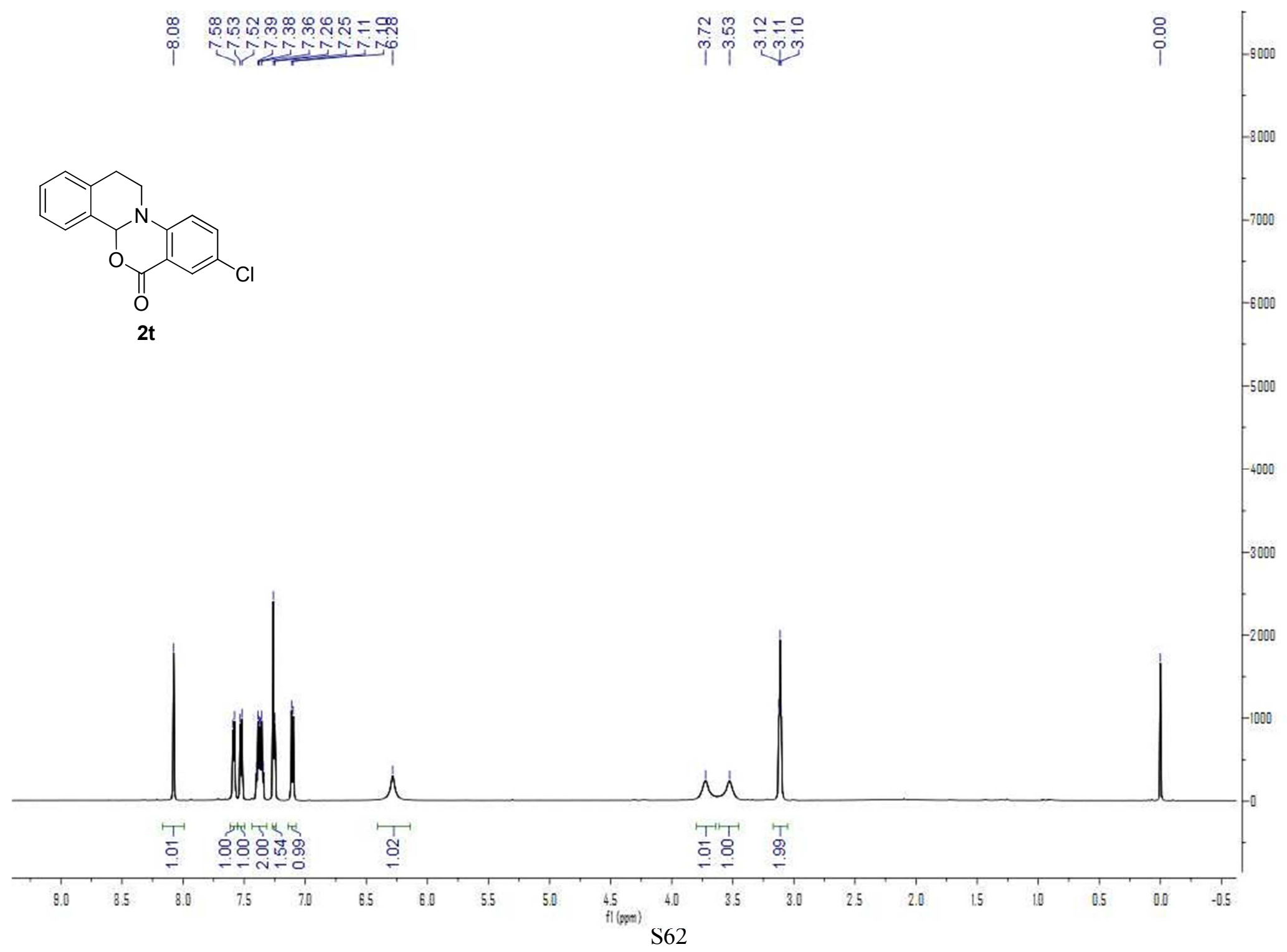



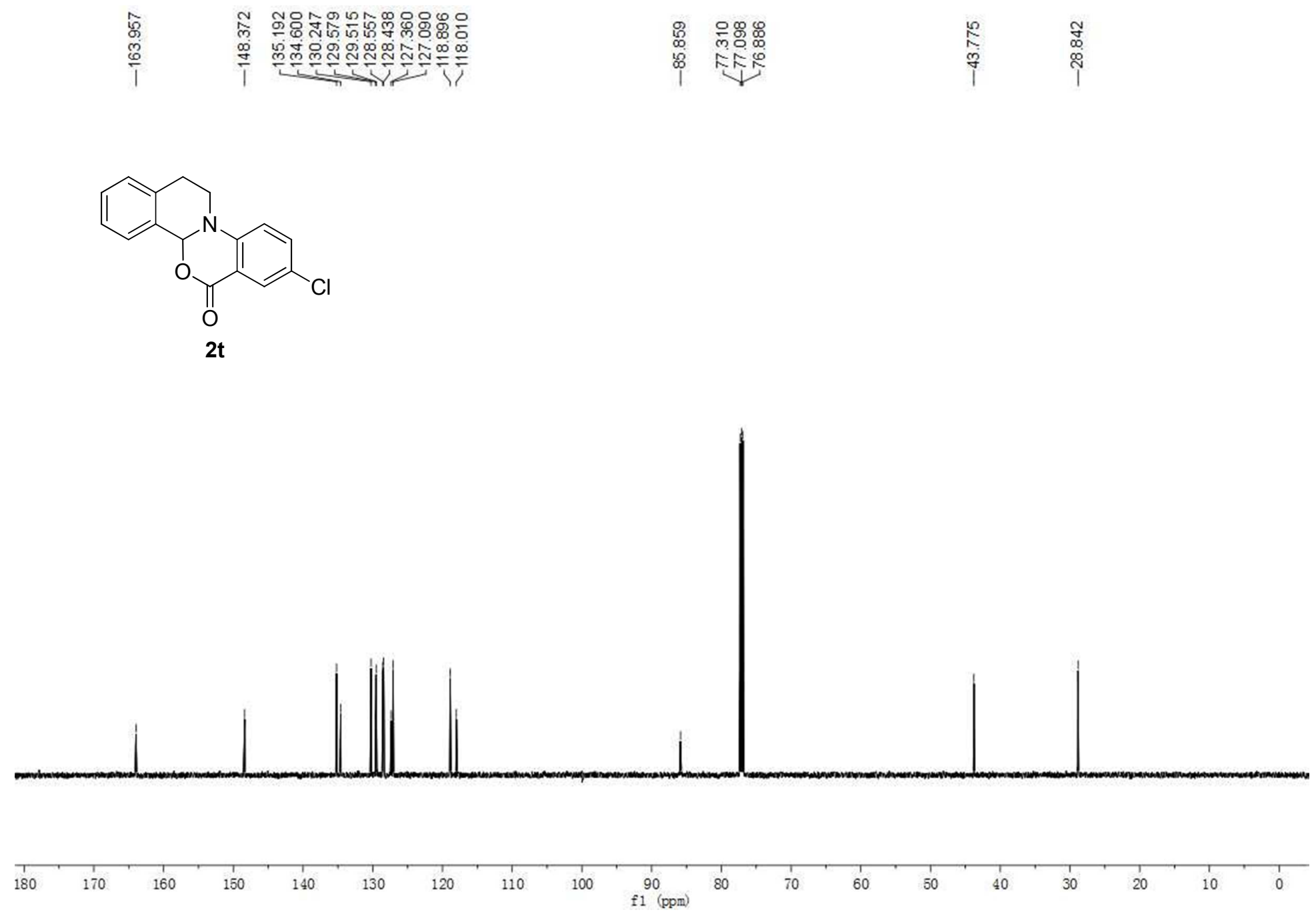


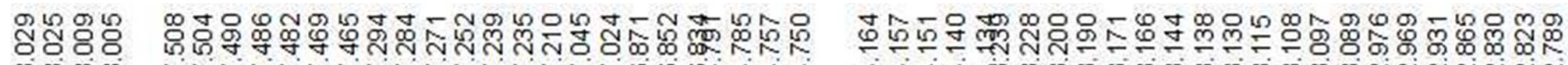

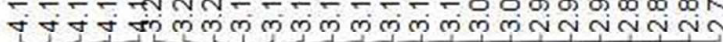
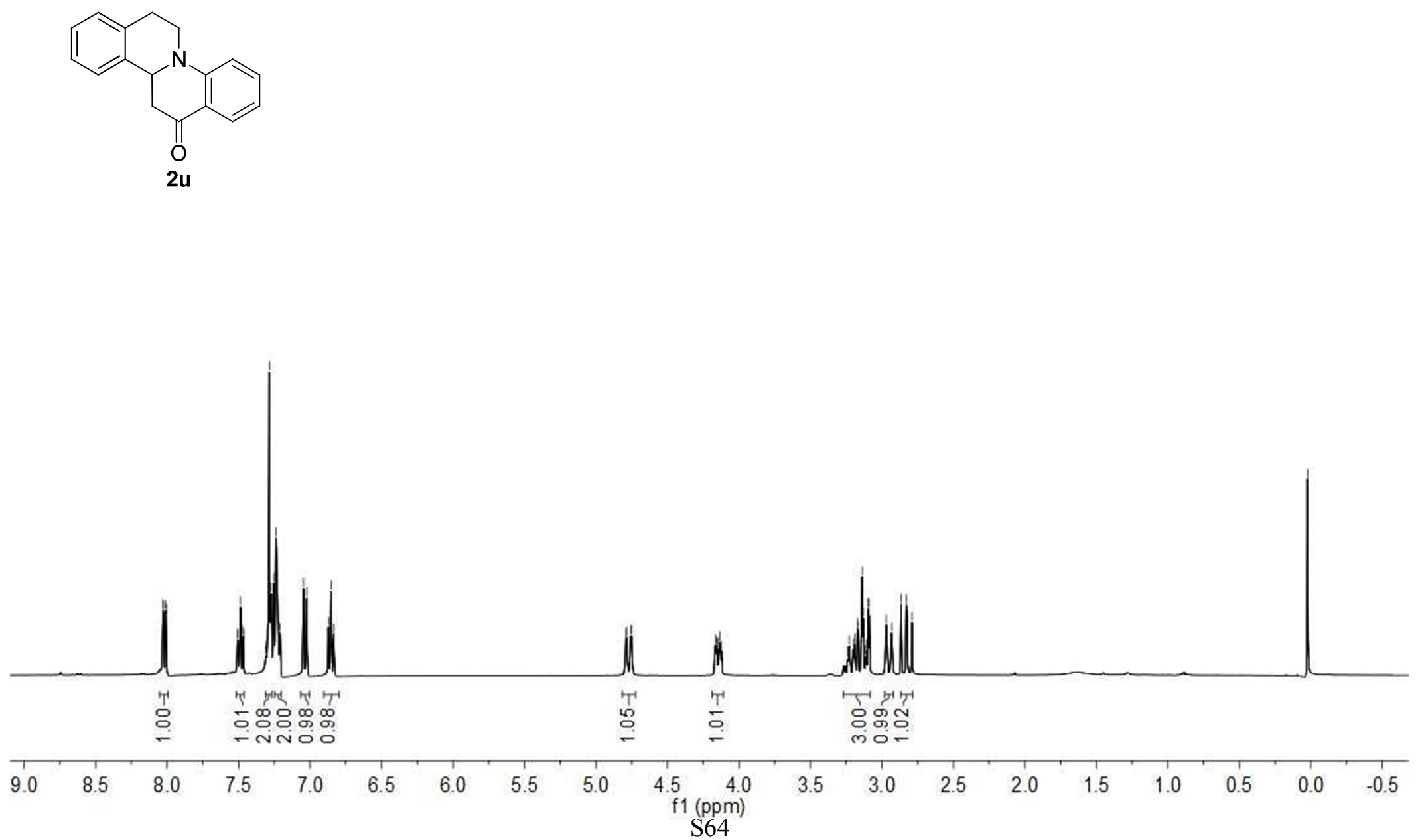


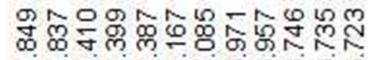

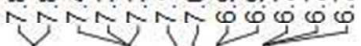

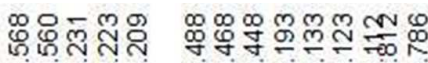

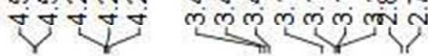

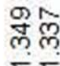

웅
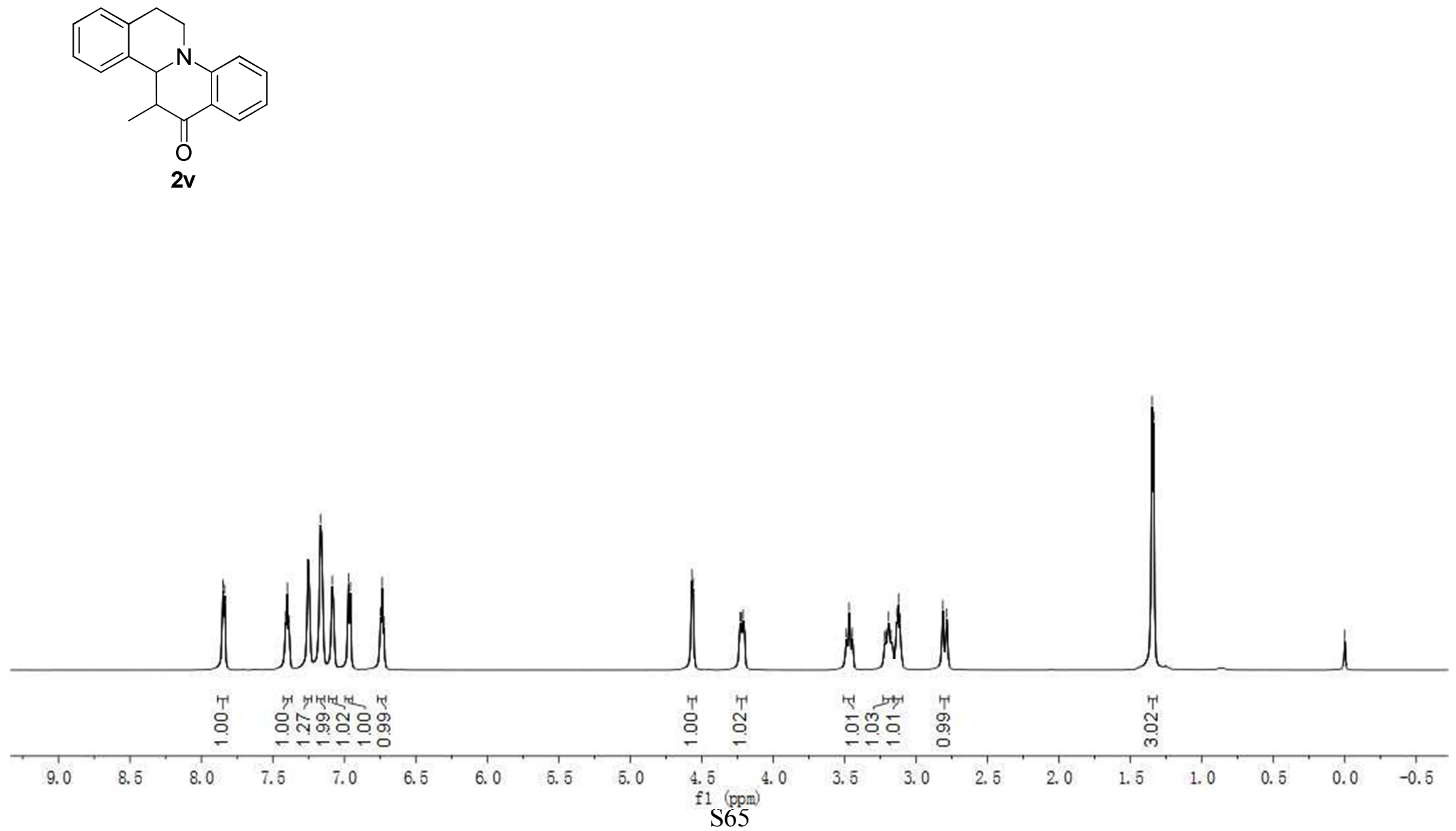


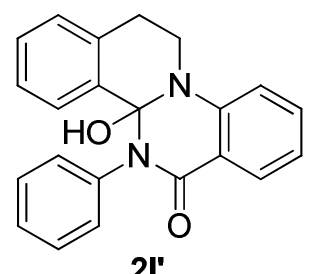

2l'

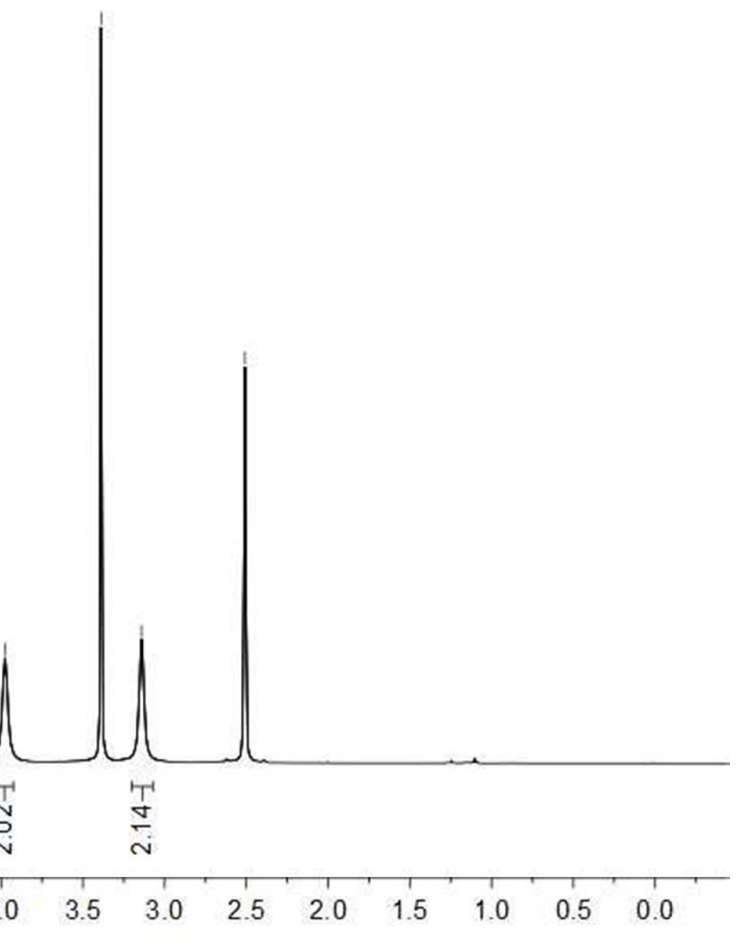



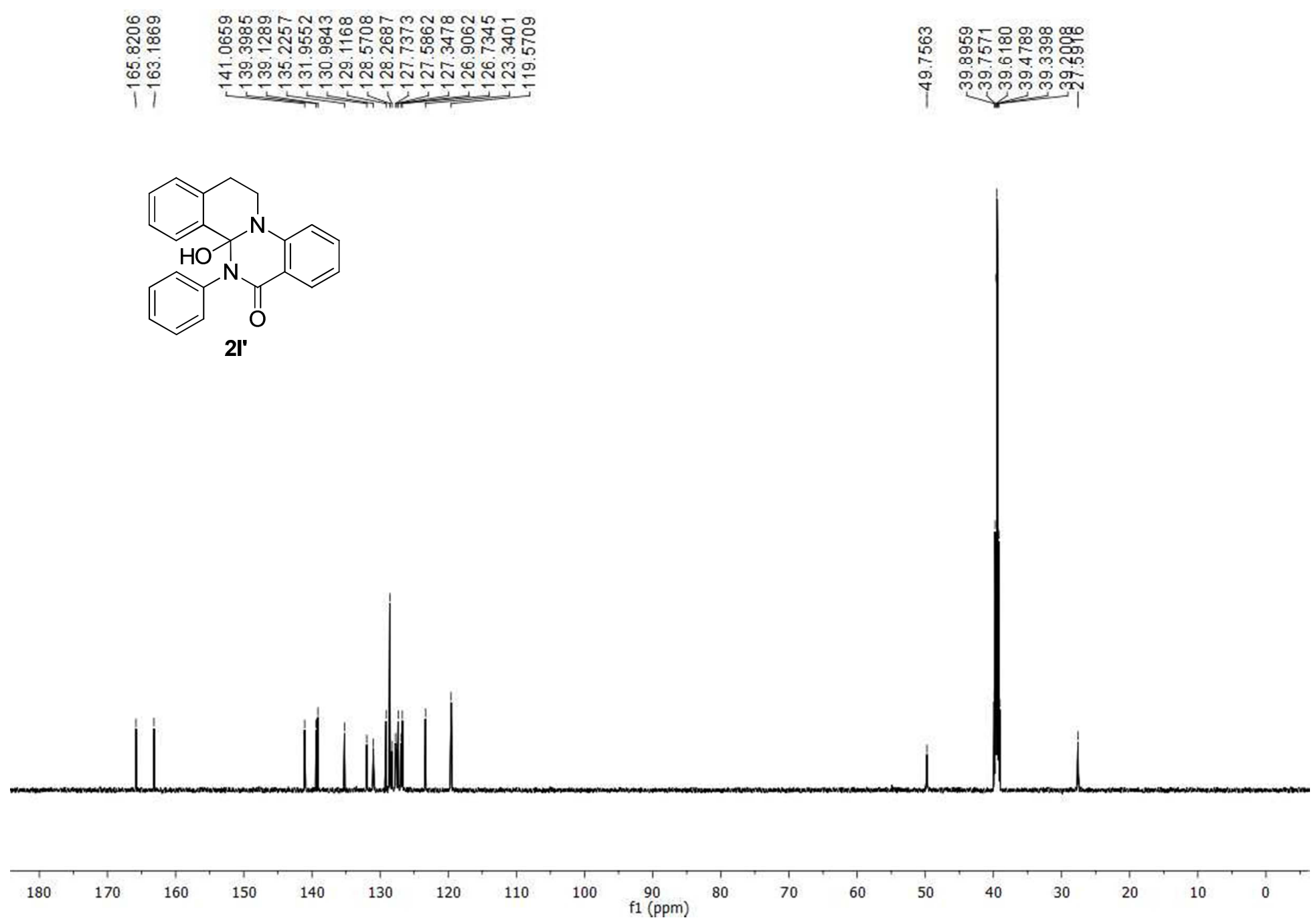

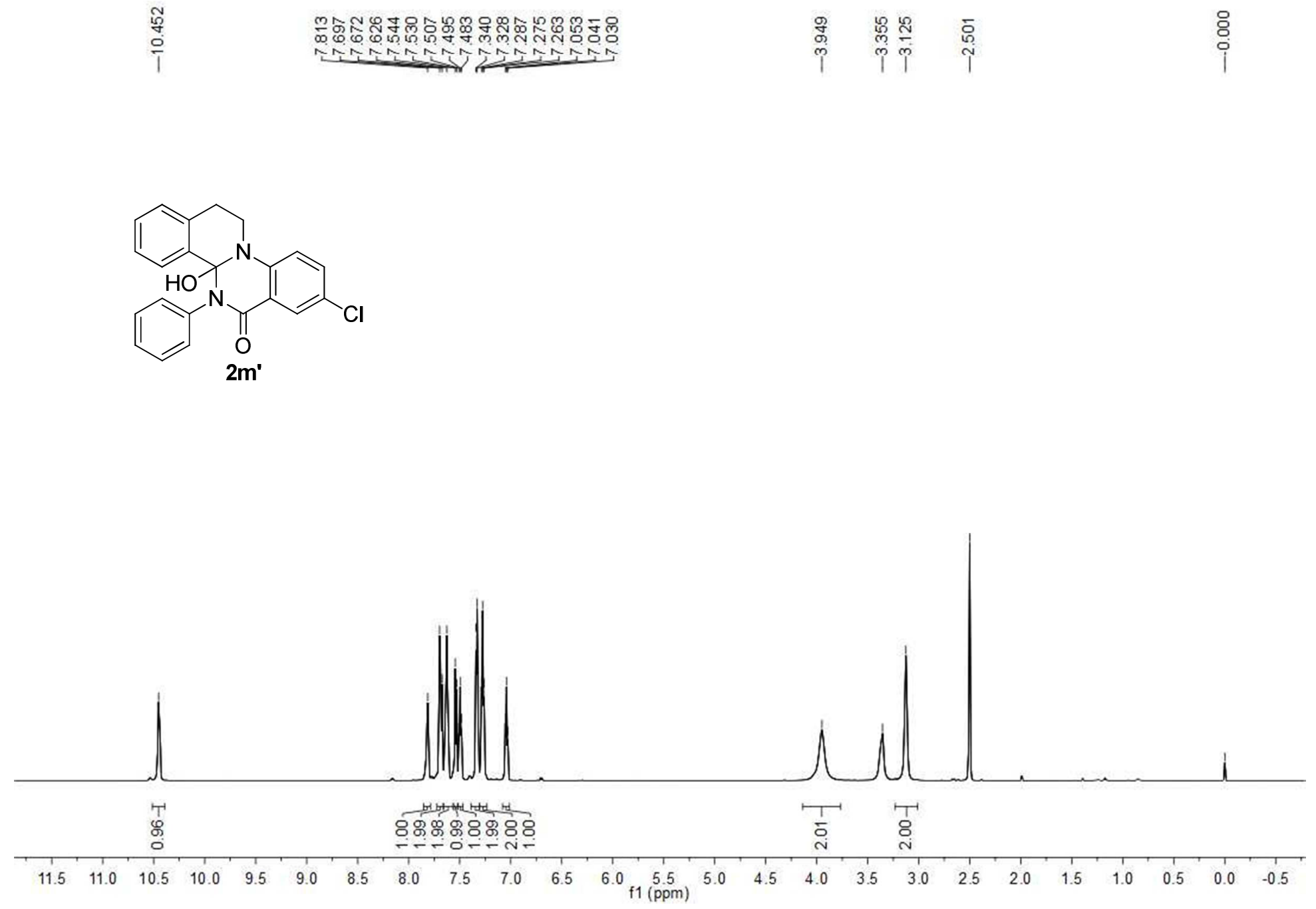

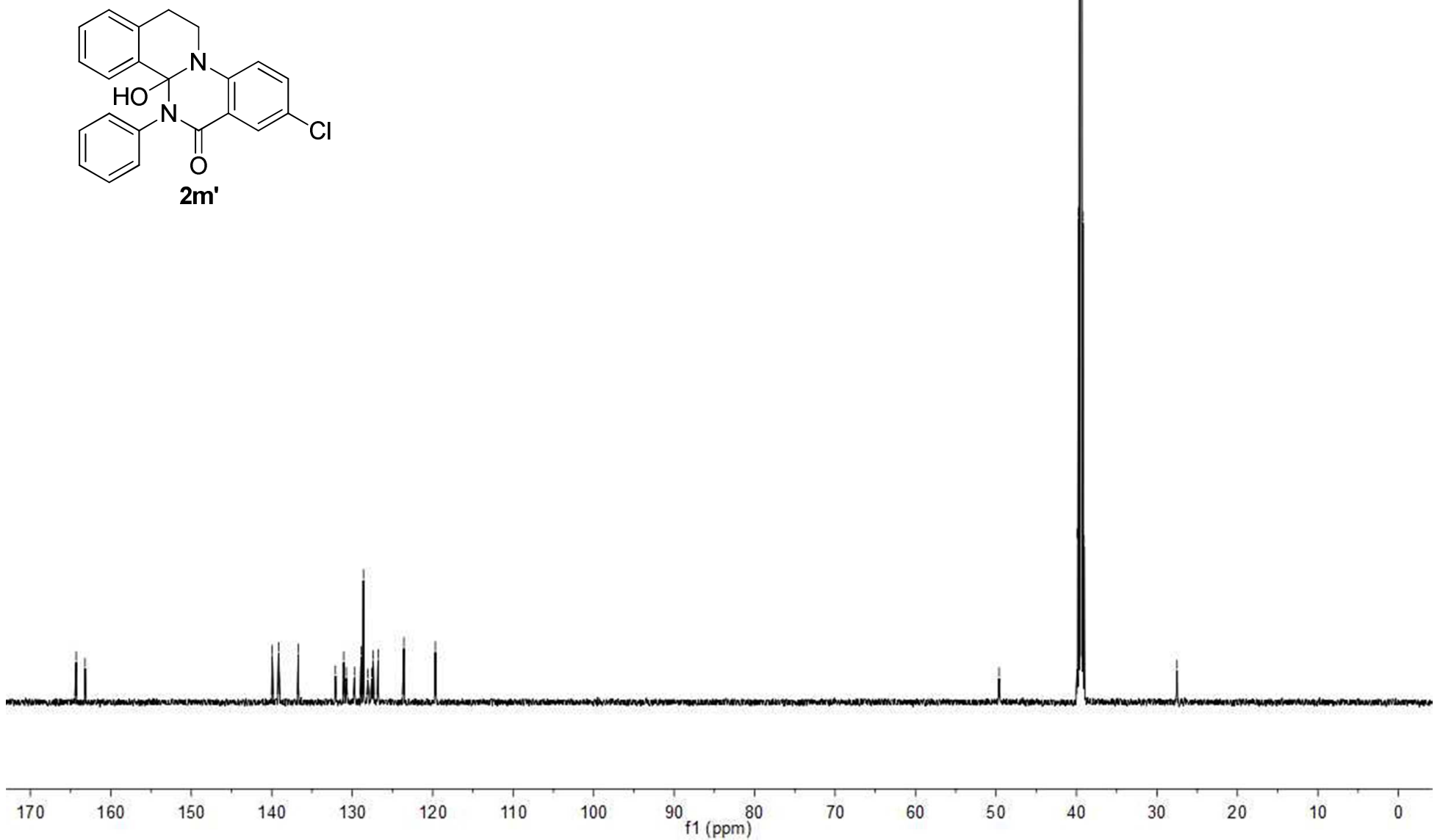